\begin{abstract}
Title of Document:

IMMIGRATION AND CONSTRUCTION: AN ANALYSIS OF THE IMPACT OF IMMIGRATION ON CONSTRUCTION PROJECT COSTS.

Sabrina Kay Golden, Doctor of Philosophy, 2008

Directed By:

Professor, Miroslaw J. Skibniewski, Department of Civil and Environmental Engineering

There are an estimated 11 million illegal immigrants currently residing in the United States. The construction industry is heavily dependent on immigrant labor, legal and illegal, for production. The construction industry, nationally, employs approximately $1,000,000$ illegal immigrants; almost one in five illegal immigrants works in construction (Passel, 2006). Immigration reform legislation will undoubtedly reduce the supply of illegal immigrants by encouraging enforcement of current laws and by enacting new legislation with harsher penalties for illegal immigration. Immigration reform may also guarantee a supply of legal immigrant labor by enacting amnesty for some illegal immigrants and by enacting a guest worker provision allowing employers to recruit and hire foreign-born workers. Depending on the form of the legislation, the cost of employing these immigrants may increase.
\end{abstract}


There is wide speculation among industry executives regarding the impact of immigration reform legislation on the construction industry. In response to industry concern, the aim of this research is to analyze the impact of immigration and immigration reform legislation on construction project costs. The main objectives of this research are to 1) to analyze the current makeup of construction industry workforces, native-born versus immigrant and legal versus illegal immigrant in the Washington, D.C. metropolitan region, 2) to predict possible effects of immigration and immigration reform legislation on worker wages, and 3) to assess the likely wage increase due to decreased supply of immigrant labor.

In the Washington, D.C. metropolitan region, the construction workforces for lowskilled trades such as concrete, masonry, drywall, painting, flooring, and roofing are comprised of approximately 55\% illegal immigrant. Based on four factors evaluated in this research: 1) prevailing wage provision in legislation, 2) forced tax compliance of the workforce, 3) market correction from currently depressed wages due to immigrant penetration into the workforce, and 4) a labor shortage resulting from a depleted supply of immigrant labor, proposed legislation could increase the cost of trade labor up to almost 70\% in this geographic area. Overall labor costs for projects could increase by almost $18 \%$, and total project costs could rise almost $12 \%$ in the Washington, D.C. metropolitan region. 


\title{
IMMIGRATION AND CONSTRUCTION: AN ANALYSIS OF THE IMPACT OF IMMIGRATION ON CONSTRUCTION PROJECT COSTS.
}

\author{
By \\ Sabrina Kay Golden \\ Dissertation submitted to the Faculty of the Graduate School of the \\ University of Maryland, College Park, in partial fulfillment \\ of the requirements for the degree of \\ Doctor of Philosophy \\ 2008
}

Advisory Committee:

Professor Miroslaw J. Skibniewski, Chair

Professor Gregory B. Baecher

Professor Ralph D. Bennett, Jr.

Senior Research Engineer, John H. Cable

Research Professor Gerald Galloway

Professor Matthias Ruth 
(C) Copyright by

Sabrina Kay Golden

2008 


\section{Preface}

In the Spring of 2006, Dr. Miroslaw J. Skibniewski, Professor, University of Maryland was contacted by a large construction company in the Washington, D.C. area. They were particularly concerned about the impact of immigration reform legislation on construction project costs. Their company, like most contractors in this area, employed a large immigrant labor force. The inquiry was the catalyst for this research.

Speculation on the impact of immigration reform at the time varied widely. The debate in Congress in May 2006 sparked rousing demonstrations by millions of immigrants nation-wide, including a call for a national "walk-off" by immigrant workers. The extent of participation and effectiveness of this protest were not convincing, but the possibility of the loss of this abundant labor resource made an impression on the construction industry officials. The Construction Industry Roundtable (CIRT) established a formal position at their policy conference on May 1, 2006, which included support for a guest worker program and provisions for gaining legal status for the large number of illegal aliens working in the United States today (Casso, 2006).

This research is an attempt to answer the concerns raised by the construction industry and provide a method for quantifying the impact on construction project costs relevant to the industry executives. 


\section{Dedication}

To my dear husband, Trent. 


\section{Acknowledgements}

I wish to express my sincere appreciation to my advisor, Dr. Miroslaw Skibniewski. His inspiration, support, and encouragement have inspired my success. I am grateful for his untiring guidance and direction over the last two years.

I would also like to thank Professor John Cable. On his urging, I embarked on this journey.

I am also grateful to my committee members, Professor Gregory Baecher, Professor Ralph Bennett, Professor Gerald Galloway, and Professor Ruth Matthias for their reviews, critiques, and guidance throughout the research process. Their comments and suggestions helped shape this dissertation.

I wish to thank my wonderful husband, Trent. His support from the very beginning and throughout encouraged my success. Thank you for always being my most avid supporter.

Finally and most importantly, I wish to acknowledge the tremendous blessing our Lord, Jesus Christ has bestowed on me with the successful completion of this dissertation. This work proceeds from His hands and is for His glory. "For God did not give us a spirit of fear, but a spirit of power, of love, and of sound mind" (2 Timothy 1:7). 


\section{Table of Contents}

Preface

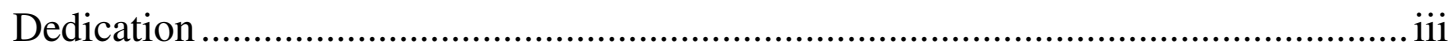

Acknowledgements ............................................................................................ iv

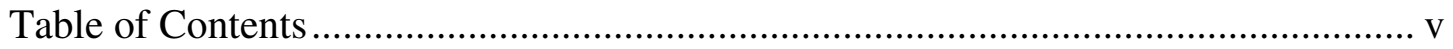

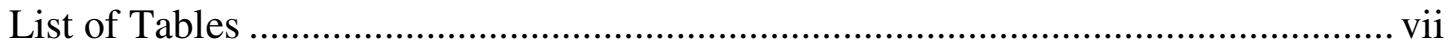

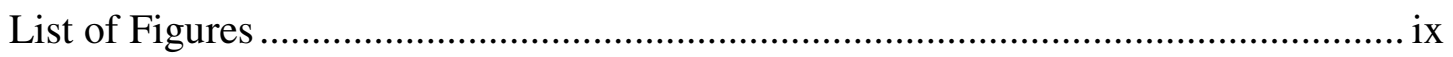

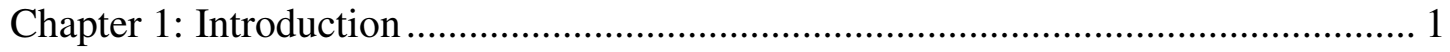

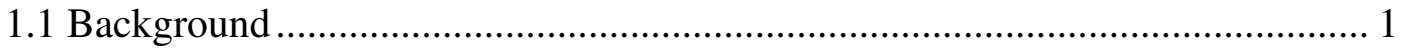

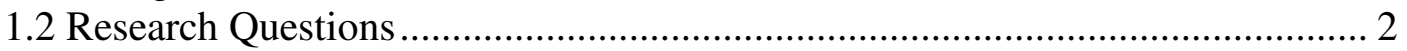

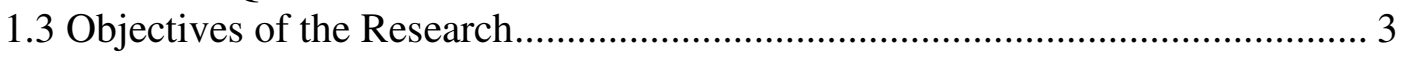

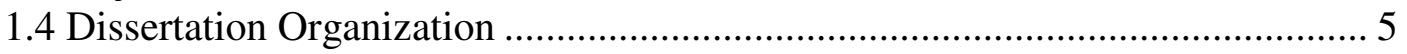

Chapter 2: Literature Review.......................................................................... 8

2.1 Estimates of Illegal Immigrants ............................................................... 8

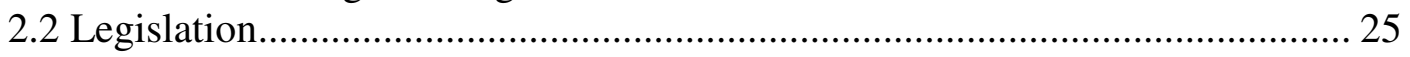

2.4 Impact of Immigration on Native-Born Wages ………….............................. 37

2.5 Literature Review Conclusions.................................................................... 48

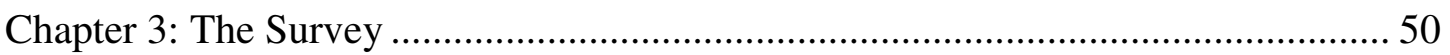

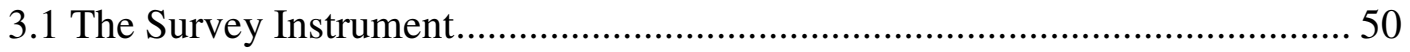

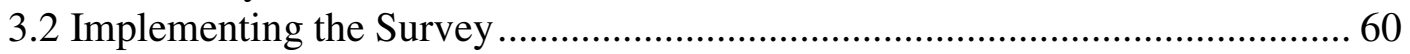

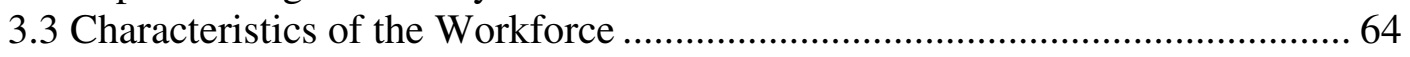

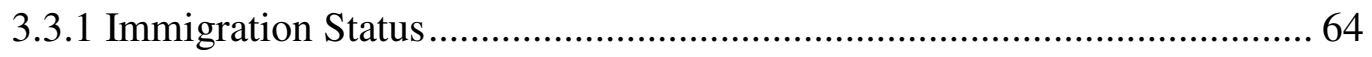

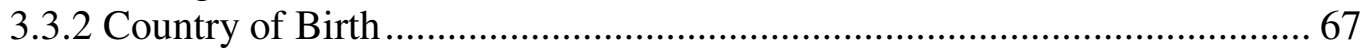

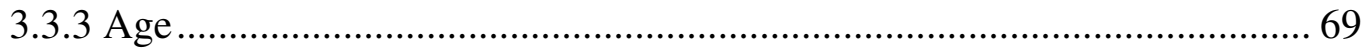

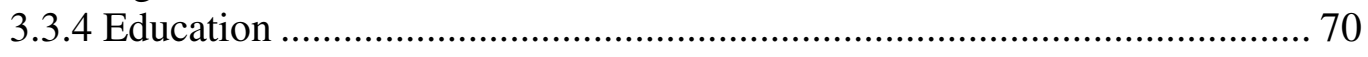

3.3.5 Wages and Benefits................................................................................. 71

3.4 Chapter Summary ......................................................................................... 77

Chapter 4: Impact of Immigration and Immigration Reform Legislation ................... 79

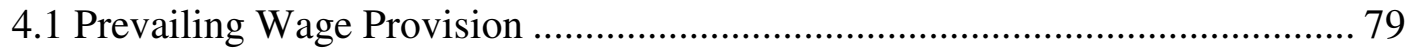

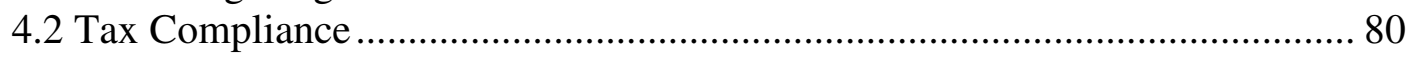

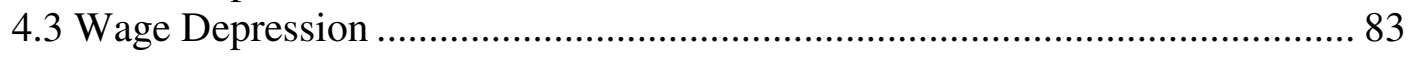

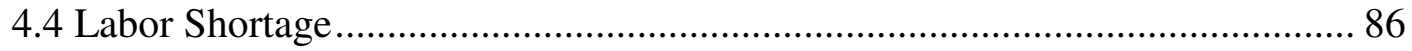

4.5 Chapter Summary ……………………………………………………..... 95

Chapter 5: Quantifying the Impact ……………………..................................... 97

5.1 Impact of Prevailing Wage Provision ............................................................... 97

5.2 Impact of Forced Tax Compliance ................................................................ 99

5.3 Impact of Market Correction from Currently Depressed Wages...................... 100

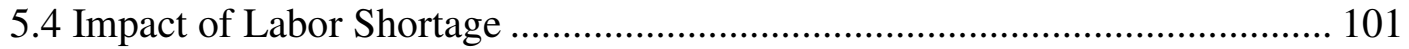

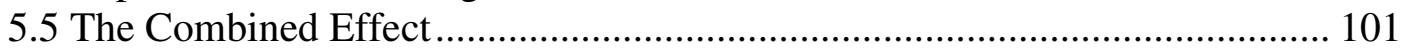

5.5.1 Scenario 1 - All Illegal Immigrants Are Allowed to Stay........................ 102

5.5.2 Scenario 2 - All Illegal Immigrants Are Forced from the Workforce..... 104

5.5.4 Scenario 3 - Somewhere in Between..................................................... 106

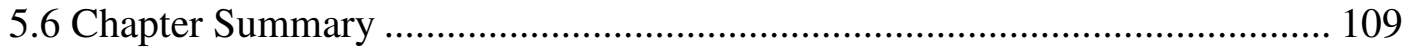


Chapter 6: Conclusions and Recommendations ................................................... 113

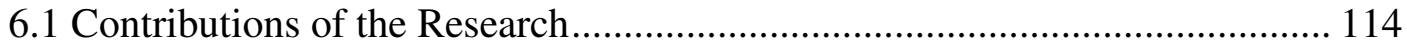

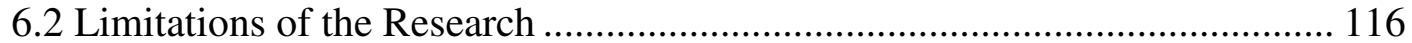

6.3 Implications for the Construction Industry ............................................ 117

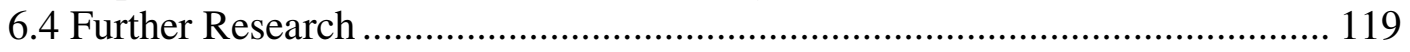

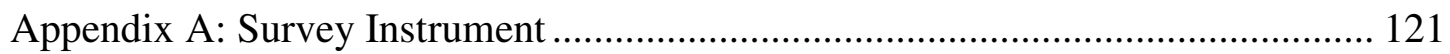

Construction Industry Labor Resources Survey .............................................. 121

Encuesta de los Recursos Laborales en la Industria de la Construcción ............... 126

Appendix B: Data for Regression Analysis ........................................................... 131

Appendix C: Residual Plots for Multiple Regression Analysis ............................... 134

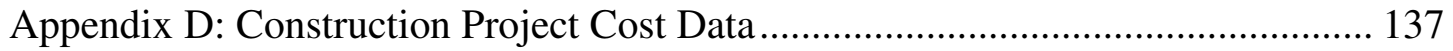

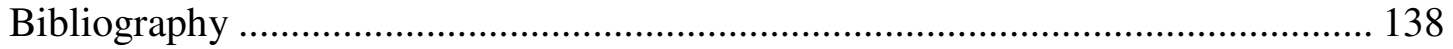




\section{List of Tables}

Table 2.1: Illegal Immigrant Share of Specific Occupations, March 2005 (in

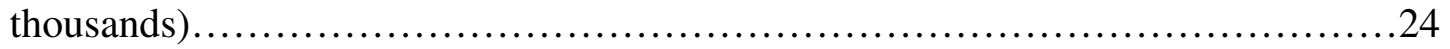

Table 2.2: Occupations by Share of Employment.............................25

Table 2.3: Comparison of Hourly Wage Data from BLS and DOL.....................

Table 2.4: Elasticity of Native Wages With Respect to the Number of Immigrants

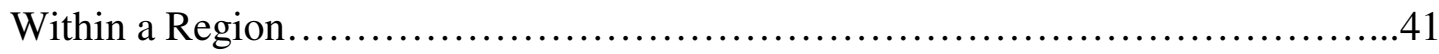

Table 2.5: Elasticity of Native Employment With Respect to the Number of

Immigrants Within a Region...........................................42

Table 3.1: Participating Projects..........................................61

Table 3.2: Participating Trades in On-Site Survey .............................64

Table 3.3: Country of Birth................................................68

Table 4.1: Multiple Linear Regression Estimate of Construction Worker Wages

Based on Job Openings and Construction Workers Employed.....................89

Table 4.2: Multiple Linear Regression Estimate of Construction Worker Wages

Based on Job Openings, Construction Workers Employed, and Average Wage of All

Workers.......................................................... 90

Table 4.3: Multiple Regression Estimate Using Transformed Variables.............93

Table 5.1: Impact on Project Costs Due to Prevailing Wage Provision Applied Only

to Illegal Immigrant Labor.............................................. 98

Table 5.2: Impact on Project Costs Due to Prevailing Wage Provision Applied to All

Labor for Immigrant-Saturated Trades.................................... 99 
Table 5.3: Impact on Project Costs Due to Forced Tax Compliance for All

Employees.......................................................... 100

Table 5.4: Impact on Project Costs Due to Increase in Wages Resulting From Market

Correction From Currently Depressed Wage Estimates....................... 100

Table 5.5: Impact on Project Costs Due to Predicted Labor Shortage................101

Table 5.6: Scenario 1 Impact on Project Costs with Prevailing Wage Provision

Applied Only to Illegal Immigrant Labor..................................103

Table 5.7: Scenario 1 Impact on Project Costs with Prevailing Wage Provision

Applied to All Labor for Immigrant-Saturated Trades............................ 104

Table 5.8: Scenario 2 Impact on Project Costs.................................. 105

Table 5.9: Scenario 3 Impact on Project Costs with Prevailing Wage Provision

Applied Only to Illegal Immigrant Labor................................. 107

Table 5.10: Scenario 3 Impact on Project Costs with Prevailing Wage Provision

Applied to All Labor for Immigrant-Saturated Trades........................... 108

Table 5.11: Scenario 3 Impact on Project Costs without Prevailing Wage

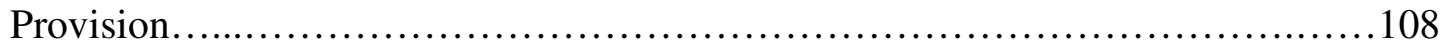

Table 5.12: Summary of Impacts to Construction Projects.......................110

Table B.1: Data for Regression Analysis.....................................131

Table D.1: Construction Project Cost Data................................... 137 


\section{List of Figures}

Figure 1.1: Phases of Research.................................................

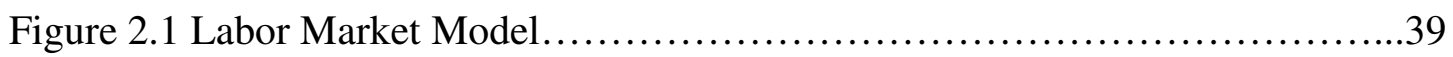

Figure 3.1: Immigration Status Cards........................................52

Figure 3.2: Residency Status Assignment.......................................57

Figure 3.3: Average Age of Workers.......................................69

Figure 3.4: Age Distribution by Country of Birth..................................70

Figure 3.5: Education Distribution by Country of Birth......................... 71

Figure 3.6: Average Wages for Workers...................................... 72

Figure 3.7: Annual Income Distribution for Workers..........................73

Figure 3.8: Annual Income Distribution by Immigration Status....................74

Figure 3.9: Average Income by Educational Attainment....................... 75

Figure 3.10: Wage Distribution by Country of Birth.......................... 76

Figure C.1: Residuals versus Construction Worker Wages (Transformed).........134

Figure C.2: Residuals versus Job Openings (Transformed).....................135

Figure C.3: Residuals versus Construction Workers Employed (Transformed)......135

Figure C.4: Residuals versus Average Wage All Workers (Transformed)..........136 


\section{Chapter 1: Introduction}

\subsection{Background}

Immigrants, legal and illegal, have migrated to the U.S. extensively over the last few years. From 2000-2005, almost 8 million immigrants settled in the United States; it is the highest 5-year period of immigration in the nation's history. Most of the immigrants lack higher education attainment. Almost $1 / 3$ of all immigrants, over age 18 and in the labor force, have not graduated from high school. For those arriving in the United States since 2000, the estimate is over 34\% (Passel 2006). For these poorly educated immigrants, mostly men, willing to work long hours for mediocre pay, the construction industry is an attractive place for employment. Likewise, the construction industry is in position to receive, employ, and train this abundant workforce.

The construction industry, according to the U.S. Department of Labor, Bureau of Labor Statistics, employs over 6 million people, accounting for nearly 5\% of the entire U.S. labor force (2008f). The value of construction in the U.S. topped $\$ 1$ trillion for the first time in 2004, amounting to $5 \%$ of the gross domestic product (Bureau of Economic Analysis, 2007). Much of the work in the construction industry requires no formal education. For the disciplines requiring some level of skill, onthe-job training is available and encouraged. Additionally, the construction market can be entered with little capital investment, enticing a large group of competitors into the field. As a result, profit margins for construction projects are typically rather small, usually 5 to $10 \%$, with substantial risk for loss. 
The United States Congress has debated immigration reform legislation extensively over the last two years. A common feature among the proposed legislation is an increased focus on enforcement of existing immigration laws, which promises to curtail illegal immigration. Other components of proposed legislation that would affect construction labor availability are amnesty for some illegal immigrants currently residing in the United States and a guest worker provision that would allow employers to hire foreign workers after showing a reasonable but failed effort to hire native-born workers. While these provisions seem to guarantee a supply of immigrant labor, the proposals are accompanied by a prevailing wage caveat that would increase the cost of the labor.

\subsection{Research Questions}

The construction industry is heavily dependent on immigrant labor, legal and illegal, for production. The construction industry, nationally, employs approximately $1,000,000$ illegal immigrants; almost one in five illegal immigrants works in construction. The construction industry is the second largest employer of illegal immigrants, behind the service occupations (Passel, 2006). Immigration reform legislation will undoubtedly reduce the supply of illegal immigrants by encouraging enforcement of current laws and by enacting new legislation with harsher penalties for illegal immigration. The supply of illegal immigrants that currently makes up $14 \%$ of the construction workforce will dissipate, and the risk of employing illegal immigrants will increase. Immigration reform may also guarantee a supply of legal immigrant labor by granting amnesty to some illegal immigrants and by enacting a guest worker provision allowing employers to recruit and hire foreign-born workers. 
While the supply of legal immigrant labor may increase, the cost of employing these immigrants may also increase, depending on the form of the legislation.

There is wide speculation among industry executives regarding the impact of immigration reform legislation on the construction industry. How many illegal immigrants are employed in construction within this specific geographic region? How does this differ from national estimates? What is the differential between native-born and legal immigrant wages and illegal immigrant wages? How will the guest worker provisions and prevailing wage determinations affect labor costs? If the supply of illegal immigrant construction workers decreases, what will be the impact on wages?

Construction industry executives are very interested in the answers to these questions. It is the goal of this research to address these concerns and to provide a method for quantifying the impact on construction project costs relevant to the construction industry.

\subsection{Objectives of the Research}

The aim of this research is to analyze the impact of immigration on construction project costs. Following are the main objectives of this research.

1. Analyze the current makeup of construction industry workforces, native-born versus immigrant and legal versus illegal immigrant in the Washington, D.C. metropolitan region.

In response to research questions: how many illegal immigrants are employed in construction within this specific geographic region and how does this differ from 
national estimates, a survey tool was created for this research and employed to workers in this region. This research was limited to the Washington, D.C. metropolitan area for two reasons. First, inquiry and sponsorship of the research came from a firm in this region. The company facilitated data gathering, allowing access to project sites and liaison and language assistance with the workers. Second, because the concentration of immigrants, legal and illegal, varies by geographic region, it is necessary to examine each region in isolation in order to determine the impact on the firms in that area. The Washington, D.C. metropolitan area was also chosen for convenience of the research as the researchers are located in this region. The methodologies presented in this research are transferable to other regions; however, the results generated here should be evaluated for the Washington, D.C. metropolitan region only.

2. Predict possible effects of immigration and immigration reform legislation on worker wages.

What is the differential between native-born and legal immigrant wages and illegal immigrant wages? Logically, immigration, in the absence of immigration reform legislation, impacts worker wages by increasing the supply of labor. This research applies existing methods of evaluating the influence of immigration on worker wages.

Objective 2 also addresses the question of how guest worker provisions and prevailing wage determinations will affect labor costs. The impact of reform legislation on worker wages is dependent on the composition of the legislation. Two additional influences on worker wages are identified in this research and evaluated based on several forms of possible legislation. 
3. Assess likely wage increase due to decreased supply of immigrant labor.

Regardless of the scope of the legislation, a decrease in the supply of illegal immigrant labor is expected. There are existing systems currently being implemented that assist employers in verifying employment eligibility of an employee. Most proposed legislation commits to extending the use of these systems, making employment of unauthorized workers more difficult. The dissipation of illegal immigrants in the workforce will presumably cause a shortage of labor in immigrantsaturated trades, resulting in an increase in labor costs from the reactive market forces of supply and demand. This research proposes a model for assessing such impact on construction worker wages. This objective addresses the question, if the supply of illegal immigrant construction workers decreases, what will be the impact on wages?

The methods developed in this research provide an important tool for industry to use in evaluating the impact of immigration and immigration reform legislation on construction project costs. This information is earnestly sought in the construction management field. While there is much research on the impact of immigration and illegal immigration on society and the economy, this is the first work strictly related to the construction industry and project costs specifically.

\subsection{Dissertation Organization}

This dissertation is organized into 6 chapters. The first chapter, Introduction, explains the background and purpose of the research. The basic problem statement is introduced and the main objectives of the research are presented. The organization of the dissertation is also explained. Chapter 2, Literature Review, presents a thorough review of the literature relevant to this research. Proposed legislation is analyzed and 
impacts to the construction industry in particular are identified. Several methodologies used in the evaluation of the impact of immigration on construction project costs are revealed and examined. Chapter 3, The Survey, introduces the survey instrument created and implemented to estimate the proportion of illegal immigrants employed in construction in the Washington, D.C. metropolitan region. The results of the survey are presented and examined. In Chapter 4, Impact of Immigration and Immigration Reform Legislation, influences related to immigration and immigration reform legislation on construction worker wages are identified. A model for evaluating the impact of a labor shortage on construction worker wages is developed. Chapter 5, Quantifying the Impact, makes a practical application of the methodologies presented in Chapter 4 to five construction projects in the Washington, D.C. metropolitan area. Finally, Chapter 6, Conclusions and Recommendations, presents the relevant findings of this research and makes recommendations to the construction industry on effective responses to differing forms of immigration reform legislation. The limitations and obstacles of this research are discussed. Further research opportunities are identified. Figure 1.1 shows the phases of this research and their relation to the organization of this dissertation. 
Phase I

Identifying the need for the research. Defining objectives for the research.

\section{Introduction}

\section{Literature Review}

Reviewing relevant literature.

Identifying applicable methods

of evaluating immigration impacts.
Phase III

Creating the survey tool.

Implementing the survey.

Evaluating the results.

\section{The Survey}

Phase IV

Identifying the immigration factors

that affect worker wages.

Evaluating and modeling those factors.

\section{Impact of Immigration and} Immigration Reform Legislation
Phase V

Practical application of the methodology developed in Phase IV.

\section{Quantifying the Impact}

\section{Phase VI}

Forming conclusions and recommendations.

\section{Conclusions and} Recommendations

\section{Figure 1.1 Phases of Research}




\section{Chapter 2: Literature Review}

\section{$\underline{2.1 \text { Estimates of Illegal Immigrants }}$}

There are several sources of data for the U.S. foreign-born population, primarily from the U.S. Census Bureau. The first is the Decennial Census, which asks questions such as place of birth, citizenship status, year of entry, ancestry or ethnic origin, residence a year ago, and language spoken at home in order to identify the foreignborn population residing in the U.S. The Decennial Census is administered through the mail and is translated into five languages (Spanish, Chinese, Vietnamese, Korean, and Tagalog). Language guides are provided for 49 other languages Constanzo, et. al., 2002).

The American Community Survey (ACS) is another source of foreign-born population data from the Census Bureau. The ACS asks the same questions related to migration status and foreign-born characteristics. The ACS is administered annually via mail service to 3 million housing units reaching every county in the U.S. (Constanzo, et. al., 2002).

The Current Population Survey (CPS), also conducted by the U.S. Census Bureau, is widely renowned as the best and most accurate source of data regarding the foreignborn population. The CPS is a monthly survey to approximately 60,000 households. Its original purpose was to collect data on the labor force characteristics of the U.S. in order to assess unemployment changes. Over the years, the monthly survey opportunity has been supplemented to gather additional information such as

educational enrollment and attainment, income and poverty, voting activity, and 
nativity and citizenship status. In addition to the recurring monthly questions, each monthly survey is supplemented with special interest items, either annually in the same month every year, or on a one-time basis. Typical monthly questions include basic demographic information such as age, sex, and race and labor force participation items. In March of every year, the Annual Demographic supplement is administered with the CPS. This survey has specific foreign-born population questions, such as place of birth and parental nativity, citizenship status, year of entry, and residence a year ago. The March CPS also uses an increased sample size of approximately 2,500 households containing at least one individual of Hispanic origin. Unlike the Decennial Census, the CPS is conducted via in-person interviews by Census Bureau employees and is available in both English and Spanish. The universe of the CPS is the civilian, non-institutional population of the U.S. and excludes those in penal or mental health institutions, nursing homes, and single, active duty military personnel living in on-base barracks, as well as college dormitory residents. Because of these characteristics of the survey, the March CPS has become the primary data source for researchers on the foreign-born population in the U.S. While the Decennial Census can be used to isolate smaller, geographically isolated populations, given the relatively small sample size of the CPS, the data are relevant and accurate only on the national level (Constanzo, et. al., 2002; Schmidley and Robinson, 1998).

While the Decennial Census, the American Community Survey (ACS), and March Current Population Survey with the Annual Social and Economic Supplement are the primary sources of information on the foreign-born population for researchers, there are four additional sources of data from the Census Bureau that provide foreign-born 
population information: the Survey of Income and Program Participation (SIPP), the National Health Interview Survey (NHIS), New York City Housing Vacancy Survey (NYCHVS), and the American Housing Survey (AHS). SIPP focuses primarily on the source and amount of income, labor force information, and government program participation. It is administered in "waves" every 4 months to the same household from 2-1/2 to 4 years apart. SIPP includes a Migration History Topical Model, which asks questions such as previous residence, when the respondents moved to their current residence, place of birth, citizenship status, year of entry, immigration status at year of entry, and year of immigration status change. This survey is not as widely used by researchers because of its limited sample size, less than 40,000 of the civilian, non-institutionalized population (Constanzo, et. al., 2002).

The NHIS collects information on the amount and distribution of illness, effects in terms of disability and chronic impairments, and health services received. In regard to foreign-born population data, the survey asks questions such as place of birth, year of entry, length of residence in the U.S., citizenship status, and parental nativity. This is the only Census Bureau survey that asks about the length of residence in the U.S. The sample size of the survey is approximately 71,000 households, and the survey is conducted annually via in-person interview by Census Bureau personnel (Constanzo, et. al., 2002).

The NYCHVS is conducted primarily to determine the vacancy rate of the New York City rental stock and to measure the quality and quantity of housing. It also includes questions on the demographic characteristics regarding foreign-born status of the city's residents such as place of birth, immigrant status, year of entry, and year of 
entry into New York City. The survey sample is approximately 18,000 rental units in New York City, and it is conducted every 3 years (Constanzo, et. al., 2002).

The AHS is used to collect data on the nation's housing. The AHS is administered nationally in odd-numbered years to 55,000 households. The AHS is administered to 41 select metropolitan areas on a rotating basis in even-numbered years as well. Foreign-born population related questions include place of birth, citizenship status, year of entry, reasons for move, and previous residence. This survey is administered via in-person interview with Census Bureau personnel (Constanzo, et. al., 2002).

Once the data are collected via these various surveys, the Census Bureau processes and edits the data in order to make it relevant to researchers. Processing raw data includes keying or coding the data into electronic format, reformatting data into usable formats such as Oracle databases in order for data to be sorted and compared, and review of the data for reasonableness, layout, and consistency (Constanzo, et. al., 2002).

Following initial data processing, the Census Bureau edits the data and certain characteristics are imputed on incomplete data per subject-matter specific Census Bureau specifications. In most cases, data are edited based on the Census Bureau specification that place of birth determines citizenship status if citizenship data are incomplete or not in agreement. If the data are so incomplete as to exclude citizenship status determination, allocation matrices are used to assign citizenship status based on year of entry and other demographic data. All nativity-related items are edited for non-response and most are edited for inconsistency. Following editing, data are weighted based on sample structure and the final microdata files are created. 
These microdata files are used to generate working tables used by the Census Bureau (Constanzo, et. al., 2002; Schmidley and Robinson, 1998).

The reliability of CPS foreign-born population data is enhanced by asking parental nativity questions which are excluded from the Decennial Census. This is important during the editing process when citizenship status is administratively assigned. Citizenship status is assigned using a multi-stage approach; first, U.S. citizenship is assigned to those who answered that they were born in the U.S., born in Puerto Rico or other U.S. territory, or born outside of the U.S. to at least one American parent. An imputed value of citizenship is then assigned to those with incomplete citizenship data based on the characteristics of other members of the same household. If this is not possible, an allocation matrix is used to match the case with incomplete data to a case with complete citizenship data. Overall, the CPS provides reliable data and information regarding the foreign-born population, and it is used extensively by researchers (Schmidley and Robinson, 1998).

At the end of the Census Bureau editing process, a citizenship status is established for respondents: "citizen" or "not a citizen." Legal or illegal immigrant status is not assigned. Further imputation and editing are necessary to make this distinction. Assignment of the probability of being an undocumented immigrant for CPS respondents designated as "not a citizen" by the Census Bureau editing process was pioneered by Dr. Jeffery Passel and Dr. Rebecca Clark in their 1998 report, Immigrants in New York: Their Legal Status, Incomes, and Taxes. The procedure outlined in this report assigns a probability of being undocumented based on age, sex, and occupation. The major assumption used in assigning this probability is that 
undocumented immigrants are restricted in occupational choice by their illegal status, and therefore, their occupational structure differs significantly from foreign-born, legal permanent residents. Another major assumption is that illegal immigrants who legalized under the Immigration Reform and Control Act of 1986 (IRCA) are representative of all illegal immigrants. The Immigration and Naturalization Service, now known as the U.S. Citizenship and Immigration Services, conducted a survey of IRCA-legalized immigrants, the Legalized Population Survey, in order to determine the occupation structure of the legalized applicants under IRCA. This survey provided the occupational structure basis for assignment of legal status based on occupation (Passel and Clark, 1998). This research technique for estimating illegal immigrants is a major contribution to the literature on illegal immigrant estimates, and it is referenced and emulated in more recent publications.

There are two research organizations that have conducted recent comprehensive analyses of Census Bureau data, primarily Decennial Census, American Community Survey, and March Current Population Survey data: the Center for Immigration Studies (CIS) and Pew Hispanic Center. Both organizations are headquartered in Washington, D.C., and they have both contributed significantly to the current literature on estimates of illegal immigrants residing in the U.S.

The Center for Immigration Studies is a non-profit organization devoted to research and policy analysis of the economic, social, demographic, fiscal, and other impacts of immigration on the United States. To understand the perspective from which their research emanates, it is important to introduce their mission statement: "It is the Center's mission to expand the base of public knowledge and understanding of the 
need for an immigration policy that gives first concern to the broad national interest. The Center is animated by a pro-immigrant, low-immigration vision which seeks fewer immigrants but a warmer welcome for those admitted" (www.cis.org).

Pew Hispanic Center is another non-profit research organization. However, it is devoted to "improving the understanding of the U.S. Hispanic population and to chronicle Latinos' growing impact on the entire nation" (www.pewhispanic.org). This perspective is moderately counter to the Center for Immigration Studies' view, as the Pew Hispanic Center focuses on the immigrant and their assimilation into society, and the Center for Immigration Studies' concentration is admittedly on limiting immigration and affecting policy related to immigration. The research and literature are at times antithetical, but also cover a wide spectrum of views on immigration and immigration reform.

Despite their differing views, both the Center for Immigration Studies and Pew Hispanic Center agree that the illegal population was approximately 11 million residing in the United States as of March 2005 (Camarota, 2005; Passel, 2006). Both the Center for Immigration Studies and Pew Hispanic Center conducted independent analyses of Census Bureau data. While the Center for Immigration Studies focuses primarily on the March CPS data, the Pew Hispanic Center has also taken into account the American Community Survey in its analysis. Most researchers agree, and the Census Bureau concurs, that the CPS alone contains accurate and reliable information on the foreign-born population at the national level. The CPS asks questions on poverty, income, welfare use, health insurance coverage, education attainment, location of birth, year of immigration, and much more. It is one of the 
most extensive surveys conducted by the government monthly with a sample size of approximately 60,000 households (Costanzo, et. al., 2002; Schmidley and Robinson, 1998).

In the Center for Immigration Studies' Backgrounder publication of December 2005, Immigrants at Mid-Decade: A Snapshot of America's Foreign-Born Population in 2005, Dr. Steven Camarota, the Director of Research at the Center for Immigration Studies, uses the answers to questions from the CPS on citizenship status, year of arrival in the U.S., age, country of birth, educational attainment, sex, receipt of benefits from welfare programs, Social Security eligibility, veteran status, and marital status in order to assign a probability of legal or illegal immigration status to each respondent. The probabilities are admittedly assigned such that they closely match other research on the total number of illegal immigrants residing in the U.S. and characteristics of the illegal population, such as that from the Urban Institute (Passel and Clark, 1998).

Contributions from this recent research include several significant statistics on the foreign-born population residing in the U.S. The data provide a snapshot of the foreign-born population taken from the March 2005 CPS. The estimate of immigrants living in the U.S. as of March 2005 is over 35 million. Between 2000 and 2005, approximately 8 million immigrants settled in the U.S. This is the highest fiveyear period of immigration in the nation's history. Of those immigrants arriving since 2000, almost half are estimated to be illegal immigrants. Almost 10 million illegal immigrants were estimated from the March 2005 CPS data, with another 1.5 million illegal immigrants arriving in the U.S. annually. Researchers estimate that roughly 
$10 \%$ of the illegal population are not counted in the CPS. Therefore, another 1 million is added to this estimate of 10 million illegal immigrants to obtain a "true" estimate of 11 million illegal immigrants residing in the U.S. as of March 2005. Illegal immigrants account for $3.3 \%$ of the nation's total population and $28 \%$ of the immigrant population (Camarota, 2005).

Immigrants account for over $12 \%$ of the total population and account for almost $15 \%$ of the nation's total workforce. Of adult immigrants, $31 \%$ have not graduated high school, compared to $9 \%$ of native-born individuals. Immigrants account for $40 \%$ of the adult workforce without a high school diploma. Educational attainment is cited as the primary indicator of economic success rather than immigration status. Immigrants earn only about $75 \%$ of the median earnings of native-born individuals. It is estimated that over $17 \%$ of immigrants lived in poverty in 2004 ; only $12 \%$ of native-born individuals were below the poverty threshold in 2004. Almost $26 \%$ of construction employees are immigrant labor (Camarota, 2005).

Approximately $30 \%$ of immigrants lack health insurance, which is 2.5 times the rate of native-born individuals. Over $17 \%$ of immigrants and their U.S.-born children use Medicaid as compared to $12 \%$ of native-born individuals. Correspondingly, almost $47 \%$ of immigrants and their children are either uninsured or use Medicaid. Almost $29 \%$ of immigrant households use some type of welfare program compared to only $18 \%$ of native-born households. Immigrants account for virtually all of the increase in public school enrollment over the last 20 years, almost $20 \%$ of the total school-age population, causing significant impact on those states with large immigrant 
populations. The conclusion of this report warns that unchecked immigration has a growing impact on the nation's economy and American society (Camarota, 2005).

In the CIS 2004 report, The High Costs of Cheap Labor: Illegal Immigration and the Federal Budget, the fiscal impact of illegal immigration is examined. The estimates in this study are based on the March 2003 CPS, using the same techniques for estimating the illegal immigrant population as discussed above. It is discovered that illegal immigration resulted in a net fiscal deficit of $\$ 10$ billion in 2002 . The net fiscal deficit is estimated at \$29 billion annually if amnesty is granted for illegal immigrants. This is based generally on illegal immigrants' low educational attainment levels and resulting low incomes and low tax payments compared to their relatively high levels of government program use such as Medicaid, public school lunch program, and Women, Infant, and Children (WIC) food subsidy program (Camarota, 2004).

More important to the research of the impact of immigration on construction industry economics are some of the estimates and assumptions used in the overall assessment of immigration found in this report. Like the report Immigrants in New York: Their Legal Status, Incomes, and Taxes conducted by the Urban Institute mentioned above, the assumption is made that current illegal immigrants are like pre-IRCA illegal immigrants in demography and occupational structure. Additionally, it is contended that current illegal immigrants, if granted amnesty, would become like immigrants granted amnesty by IRCA in occupational structure, demography, and social program use (Camarota, 2004). 
The report assumes only 55\% tax compliance among illegal immigrants (Camarota, 2004). This assumption is based on two studies in particular that reported on tax compliance by illegal immigrants (North and Houstoun, 1976; Rea and Parker, 1993). In the report, Immigrants in New York: Their Legal Status, Incomes, and Taxes, an estimate of $60 \%$ tax compliance is purported based on the same two research studies (Passel and Clark, 1998).

The rate of tax compliance among illegal immigrants used in these studies may be low. The earlier report dealing with tax compliance, The Characteristics and Role of Illegal Aliens in the U.S. Labor Market: An Exploratory Study published in 1976, was the result of a survey administered to 793 apprehended illegal immigrants who had worked for wages in the United States for at least two weeks. The interviews were conducted in 19 geographic locations across the U.S.: Los Angeles, New York City, San Antonio, Chicago, Miami, San Francisco, Detroit, Seattle, and Washington, D.C. The statistical relevance of the data from the 1976 study is not purported. The authors admit the sampling strategy does not reveal statistically sound data. However, insomuch as the sample is representative of the illegal workers in the country at that time, the data has been used extensively to make assumptions about the illegal workforce, (North and Houstoun).

This study found that $77.3 \%$ of illegal immigrants interviewed had Social Security taxes withheld. For those working in non-farm jobs, the compliance rate for Social Security taxes was even higher, $80.5 \%$. During the time of the research, there were instances that employers were obligated to pay Social Security taxes, but could forego withholding income taxes, particularly in the case of low income-earning employees. 
The report indicated that $73.2 \%$ of illegal immigrants interviewed had federal income taxes withheld (North and Houstoun, 1976). Today, employers must withhold income taxes on all non-resident alien employees; in addition, non-resident alien employees are only allowed to claim one exemption for withholding purposes.

The more recent study of tax compliance among illegal immigrants was conducted in San Diego County. The study, Illegal Immigration in San Diego County: An Analysis of Costs and Revenues, was commissioned by the California State Legislature as part of a broader study on the fiscal impact of illegal immigrants on public agencies in the state. The report is based on a survey conducted of 308 self-identified illegal immigrants from a variety of locations throughout the county: medical clinics, social service agencies, soup kitchens, detention facilities, street corners, migrant encampments, and local day-labor gather points. This report purported approximately 54\% tax compliance among illegal immigrants (Rea and Parker, 1993).

The 1976 study, The Characteristics and Role of Illegal Aliens in the U.S. Labor Market: An Exploratory Study reports only $27.9 \%$ tax compliance in regions bordering Mexico (North and Houstoun, 1976). This compares to the 54\% reported in 1993 in the study, Illegal Immigration in San Diego County: An Analysis of Costs and Revenues (Rea and Parker, 1993). The noted increase is likely due to the change in legislation during that time period assessing penalties to employers who knowingly hire illegal immigrants.

Of those respondents to the 1993 survey, 24.2\% worked in construction. This was second only to landscaping with $29.1 \%$. Agriculture was third, with $16.3 \%$. This dispersion is heavily dependent on the locations where the survey was administered. 
Day-labor sites are known for attracting construction workers, which could account for relatively high number of construction workers noted. At any rate, the randomness of the sample and therefore, the statistical relevance of the data are questionable (Rea and Parker, 1993).

The statistics in The Characteristics and Role of Illegal Aliens in the U.S. Labor Market: An Exploratory Study are strikingly similar to more recent statistics on illegal immigrants. In 1976, the seven states with the largest numbers of immigrants were the same as 2005: California, New York, Texas, Florida, New Jersey, Illinois, and Massachusetts. In 1976, immigrant construction workers earned approximately $42 \%$ of their native-born counterparts; currently, immigrants earn approximately $75 \%$ of native-born wages. From the 1976 study, 16\% of illegal immigrants worked in construction as compared to $19 \%$ in 2005 . Twenty-eight percent of respondents reported use of Medicaid equivalent in 1976 compared to $24.2 \%$ according to 2005 estimates. In 1976, food stamp programs were secured by $1.3 \%$ of survey respondents compared to $7 \%$ according to 2005 estimates, and another $0.5 \%$ of respondents collected welfare payments compared to $1.8 \%$ in the 2005 research. Sixty percent reported Mexico as their country of origin as compared to $57 \%$ in 2005 . Just as in 1976, 2005 illegal immigrants are low education, low income, and high poverty. Most are also relatively young men. In 1976, an estimated $85 \%$ of illegal immigrants had not completed high school compared to $31 \%$ in 2005 . As demonstrated by this comparison, conditions in the U.S. have improved for illegal immigrants, but the general characteristics of those illegal immigrants attracted to the U.S. have not (Rea and Parker, 1993; Camarota, 2005). 
With a different perspective on immigration and immigration reform, the Pew Hispanic Center has produced several recent articles on immigration with significant and relevant findings. It is important to note the difference in terminology between CIS research reports and Pew Hispanic Center research. CIS uses the term illegal immigrant broadly and does not make any further distinction. In CIS research, immigrants are either legal or illegal. In Pew Hispanic Center research reports, researchers categorizes immigrants as legal permanent residents (LPR), naturalized citizens, unauthorized migrants, temporary legal residents, and refugee arrivals. The unauthorized migrants include visa overstays, entries without inspection or clandestine entrants, non-immigrants or not "legal," and "quasi-legal" immigrants. "Quasi-legal" immigrants include those with Temporary Protected Status (TPS) or those eligible for the Deferred Enforced Departure (DED) program, Nicaraguan and Central American Relief Act beneficiaries, asylum applicants, fiancé, spouse, or child visa applicants - known as adjustment applicants, and Legal Immigrant Family Equity Act (LIFE) section 245(i) beneficiaries. "Quasi-legal" immigrants account for 1 to 1.5 million immigrants by Pew Hispanic Center estimates (Passel, 2006). These immigrants in many cases are fully authorized to live and work in the U.S. but only temporarily. Temporary Protected Status and Deferred Enforced Departure have expiration dates associated with their programs. For the other "quasi-legal" immigrants, their status is not permanent until adjudicated and approved through the appropriate venue (Passel, 2005). Both CIS and Pew Hispanic Center include "quasilegal" immigrants in their estimates of illegal or unauthorized immigrants. 
Of significant importance to the research on estimating illegal immigrants is the 2004 report by Passel, Van Hook, and Bean which explains in detail the residual method used to estimate unauthorized migrants. In addition to historical context of immigrant estimates since the 1980's, the report defines the residual methodology used in this report and in future research by the Pew Hispanic Center. The residual method essentially subtracts the known legal immigrant population from the total foreignborn population in order to establish the unauthorized migrant population (Passel, et. al., 2004).

Using the residual method and the probabilistic determinations discussed in the 1998 report, Immigrants in New York: Their Legal Status, Incomes, and Taxes, the Pew Hispanic Center conducted a detailed analysis of the March 2005 CPS data (Passel, 2006). The results are similar to that of the CIS research and estimates using the same data (Camarota, 2005). Notably, the Pew Hispanic Center finds approximately 11 million unauthorized migrants residing in the U.S. in March 2005. Of those, 7.2 million are employed in the U.S. labor force, with 1.4 million in the construction industry, which comprises $14 \%$ of the entire construction workforce. Unauthorized migrants account for 30\% of the foreign-born population (Passel, 2005, 2006; Pew Hispanic Center, 2006a, 2006b).

Most unauthorized migrants originate from Mexico - over 6 million - 56\% of all illegal immigrants. Another 2.5 million come from other Latin American countries $22 \%$ of all illegal immigrants. Thus, over $75 \%$ of the illegal immigrant population is Latin American. The Pew Hispanic Center estimates that between 80 and 85 percent 
of Mexican immigrants that arrived within the last ten years are unauthorized (Passel, 2006).

Ninety-four percent of illegal male immigrants participate in the U.S. workforce, compared to $86 \%$ of legal male immigrants and $83 \%$ of native-born adult males. The most concentrated occupations include farming, cleaning, construction, food preparation, production, and transportation. Illegal immigrants represent $36 \%$ of all insulation workers, $29 \%$ of all roofers, $28 \%$ of all drywall installers, ceiling tile installers, and tapers, $27 \%$ of all construction helpers, $25 \%$ of all construction laborers, brick masons, block masons, and stone masons, $22 \%$ of all painters, $21 \%$ of all cement masons, concrete finishers, and terrazzo workers, and $20 \%$ of all carpet, floor, and tile installers and finishers (see Table 2.1 (Passel 2006)). These construction trades are referred to as the immigrant-saturated trades. 


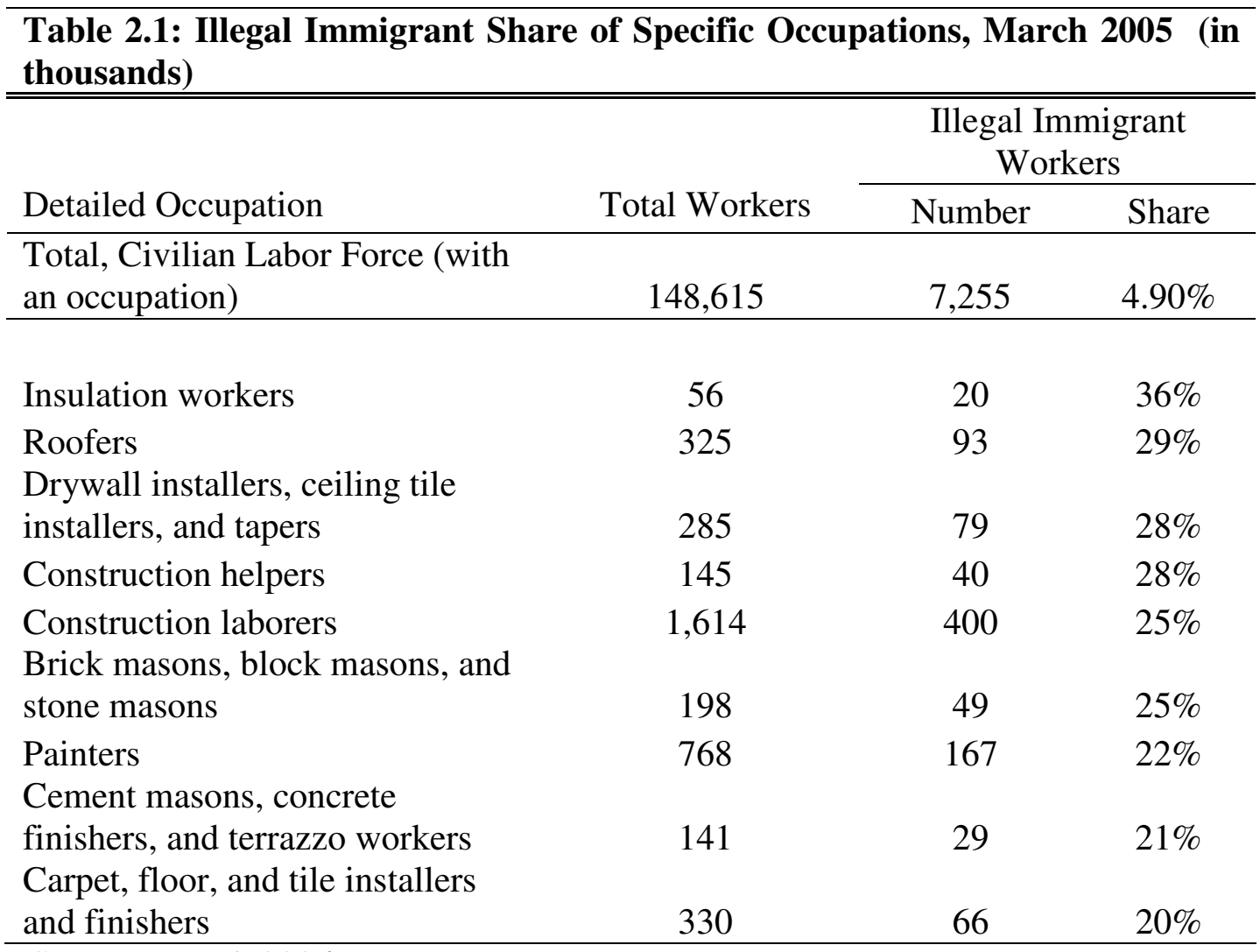

(Source: Passel, 2006)

Additionally, Pew Hispanic Center has sponsored other research with relevant findings in the area of illegal immigration and the workforce. More specifically, among immigrant Hispanic workers, construction is the largest employer $-17 \%$ of foreign-born Hispanics work in construction, compared to only $7.2 \%$ of native-born workers. Distribution of native-born Hispanics more closely resembles the nativeborn distribution as a whole, with only $7.8 \%$ of native-born Hispanics working in the construction industry (Kochhar, 2005).

Including legal Hispanic immigrants, the occupational demography changes slightly. Forty-eight percent of all plasterers and stucco masons are foreign-born Hispanic workers (legal and illegal), 45\% of drywall installers, ceiling tile installers, and 
tapers, $38 \%$ of cement masons, concrete finishers, and terrazzo workers, $35 \%$ of roofers, $31 \%$ of construction laborers, $29 \%$ of painters, $29 \%$ of insulation workers, brick masons, block masons, and stone masons, and $28 \%$ of construction helpers (see Table 2.2 (Kochhar, 2005)).

Table 2.2: Occupations by Share of Employment

\begin{tabular}{lcc}
\hline \hline \multirow{2}{*}{ Detailed Occupation } & \multicolumn{2}{c}{$\begin{array}{c}\text { Foreign-born Hispanic } \\
\text { Workers }\end{array}$} \\
\cline { 2 - 3 } & Number & Share \\
\hline Plasters and stucco masons & 18,572 & $48 \%$ \\
Drywall installers, ceiling tile installers, and & & \\
tapers & 95,595 & $45 \%$ \\
Cement masons, concrete finishers, and & & \\
terrazzo workers & 43,508 & $38 \%$ \\
Roofers & 94,041 & $35 \%$ \\
Construction laborers & 386,238 & $31 \%$ \\
Painters & 211,655 & $29 \%$ \\
Insulation workers & 13,159 & $29 \%$ \\
Brick masons, block masons, and stone & & \\
masons & 68,831 & $29 \%$ \\
Construction helpers & 34,318 & $28 \%$ \\
\hline Source Kochhar, 2005)
\end{tabular}

(Source: Kochhar, 2005)

Overall, almost $14 \%$ of the construction industry workforces are comprised of illegal immigrants. This trend in hiring practices will have a significant impact as the industry braces for immigration reform.

\section{$\underline{2.2 \text { Legislation }}$}

In order to understand the status of immigration reform legislation, a review of the legislative process in the United States is necessary. Legislative power in the United States is granted to the U.S. Congress, made up of two bodies, the House of Representatives and the Senate. All laws must pass, in identical form, both the House and the Senate and be approved by the Executive Branch of the government, the 
President of the United States. If the President chooses to veto a bill, the Congress may still pass the bill by two-thirds vote in both the House and the Senate. The House of Representatives currently has 435 members elected from all districts of the 50 states. Its membership is based on the total population of each state. The Senate has 100 members - 2 elected officials from each state regardless of state population (Constitution of the United States, 1787).

The process of legislation, in basic terms, begins when bill is proposed in either the House or Senate by a member of Congress. The bill is passed to the requisite legislative committee for consideration. In the case of immigration reform, the Judiciary Committee has primary jurisdiction. The committee researches and compiles the views on both sides of the proposal with one of four conclusions: 1) report favorably to the whole House/Senate with or without amendments, 2) report adversely to the whole House/Senate, 3) report without recommendation to the whole House/Senate, or 4) "table" the proposal, preventing further action on the bill. Once out of committee, the proposal is considered, with amendments, and passed to either the House or Senate, depending on where the legislation originated. The alternate House of Congress passes the bill to the committee for comment and consideration and then back to the whole House/Senate for final action. Again, out of committee, the bill is considered, with amendments and passed back to the other House of Congress. If resolution between the Houses of Congress cannot be reached on the proposal, a conference in convened. The differences between the bills are reconciled in conference and then ratified by both houses before being presented to the President 
in final form. If signed, the proposal, finally, becomes the law of the land (Johnson, 2003).

A basic understanding of this process is essential in the discussion of immigration reform legislation in the United States. Few issues are as politically-charged and garner such widely diverse, intense opinions in the country as immigration. Immigration ranked in the top five issues considered in the 2006 elections by voters, preceded only by the war in Iraq, the economy, terrorism, and affordable health care. The debate in Congress in May of 2006 sparked rousing demonstrations by millions of immigrants nation-wide, including a call for a national "walk-off" by immigrant workers. The extent of participation and effectiveness of this protest were not convincing, but the possibility of the loss of this abundant labor resource made an impression on construction industry officials. The Construction Industry Roundtable (CIRT) established a formal position at their policy conference on May 1, 2006, which included support for a guest worker program and provisions for gaining legal status for the large number of illegal immigrants working in the United States today (Casso, 2006).

There are two basic philosophies on immigration reform that dominate in the United States, amnesty and enforcement. The House and the Senate have proposed differing versions of immigration reform, one favoring enforcement, another tending toward amnesty, and most recently, a compromise including both provisions. Currently, there are three versions of immigration reform legislation: one bill proposed and passed in the U.S. House of Representatives, one bill proposed and passed in the U.S. Senate, and the most recent bill proposed in the Senate but failed to pass. 
The first bill introduced in the House of Representatives on December 6, 2005, HR 4437, is titled The Border Protection, Anti-terrorism, and Illegal Immigration Control Act of 2005. Technically, once passed by either House of Congress, a bill becomes an 'act,' but not yet law. This bill passed the House on December 16, 2005, with amendments. It was forwarded to the Senate on December 17, 2005. The Senate referred the bill to its Judiciary Committee on January 27, 2006, where it was "tabled," and no further action was taken. The major provisions of the House bill of particular interest to the construction industry include:

- Requirement for construction of 700 miles of fencing along the border with Mexico in conjunction with deployment of surveillance technology in order to detect and prevent illegal border crossings. This fence is estimated to cost almost \$4 million per mile. The construction cost of seven hundred miles of fence would amount to almost $\$ 3$ billion. This indicates a tremendous opportunity for construction companies working in the border area.

- Mandated use of the Employment Eligibility Verification System by employers. The legislation requires that the Department of Homeland Security (DHS) establish and administer an employment eligibility status database through which an employer can verify the eligibility for employment of potential employees. This system is to be administered in consultation with the Commissioner of Social Security. The system is to be phased in over several years for previously hired individuals. There is also a provision that establishes a responsibility of DHS to investigate possible fraudulent use of 
Social Security numbers when identical numbers are submitted by multiple employers.

Over twenty years ago, the Immigration Reform and Control Act of 1986 made it unlawful for employers to hire illegal aliens and required employers to verify eligibility by a review of an employee's documents. Prevalent document fraud has nullified the effect of this law. It is estimated that almost one-third of immigrant documentation is fraudulent (Camarota, 2005). The Illegal Immigration Reform and Immigrant Responsibility Act of 1996 established three pilot programs of the Employment Eligibility Verification System, whereby Social Security numbers and alien identification numbers of new hires are checked against Social Security Administration (SSA) and DHS records in order to verify the validity of an employee's documents.

Under The Border Protection, Anti-terrorism, and Illegal Immigration Control Act of 2005, this pilot program would be extended and immediately enforced for all new hires. Employers would be required to check the eligibility status of all new hires within two years of enactment. On a voluntary basis, employers could check the eligibility of previously hired employees two years following enactment. By three years following enactment, all employers of immigrants working for federal, state, and local governments or in government buildings, on military bases, nuclear energy sites, weapons sites, airports, and other critical infrastructure sites must have verified the eligibility of employees through this system. Six years following enactment, all employers must have completed this verification for all immigrant employees. This requirement applies to day-labor 
sites and hiring halls as well. If the estimates are accurate, this requirement by itself could reduce the immigrant workforce by one-third over six years.

- Elimination of the Diversity Immigrant Visa ("Green Card Lottery") program. This is another measure that potentially reduces the size and availability of the immigrant workforce.

- Prohibiting grants to state and local governments that harbor illegal aliens through a sanctuary policy. It also requires the federal government to take custody of illegal immigrants apprehended by local officials. Sanctuary policies are usually adopted by local governments, i.e. cities or counties rather than states. No state, yet, has broadly adopted a sanctuary policy. Sanctuary policies basically direct local officials not to notify the federal government of illegal immigrants living in their cities. The federal government has jurisdiction over all matters relating to immigration. Some sanctuary policies also eliminate the distinction between illegal and legal immigrants, which allows illegal immigrants to benefit from state services. This provision in the House bill will, in the simplest of terms, make it harder for illegal aliens to live and prosper in the United States. Sanctuaries allow illegal immigrants to live without fear of being caught and deported. With the requirement of local officials to notify the federal government of their knowledge of the presence of illegal immigrants in their localities, this freedom of existence is diminished. The requirement to notify federal officials would of course extend to health and human services officials as well as law enforcement officials. So, not only are criminals affected, those seeking assistance or 
medical treatment will be scrutinized as well. The House bill also makes it illegal to give aid to illegal immigrants, prohibiting charities from giving aid to illegal immigrants without notification to the federal government of their presence. This is another provision discouraging the presence of illegal immigrants.

- Increase in penalties for production and use of fraudulent documents and establishment of a Fraudulent Documents Center within DHS to better track the sources of fraudulent documents. This requirement would also reduce the ability of illegal immigrants to procure documents for employment, thereby reducing the ability of illegal immigrants to gain employment.

- Increase in penalties for employing undocumented workers to $\$ 7,500$ for first offense, $\$ 15,000$ for second offenses, and $\$ 40,000$ for subsequent offenses.

In essence, the House bill makes it harder for employers to plead ignorance in hiring illegal immigrants and makes it fiscally prohibitive to get caught doing so. One of the more politically volatile aspects of the bill is its lack of inclusion of any type of guest worker program or provisions for legalization for the 11 million illegal immigrants currently residing in the United States. The House bill focuses primarily on enforcement and discouragement of illegal immigration. The enactment of this bill would reduce the immigrant workforces available within the construction industry, creating labor shortages in certain disciplines. There is no relief available in this bill for such shortages.

The second bill, introduced in the Senate on April 7, 2006, S 2611, is titled Comprehensive Immigration Reform Act of 2006. The bill passed the Senate on May 
25, 2006, with amendments. Rather than extensively modify the House bill, the Senate chose to establish its version of immigration reform and proposed this alternative bill. The major provisions of the Senate bill of particular interest to the construction industry include:

- Requirement for reinforcement of several miles of fencing along the Mexico border and construction of 370 miles of additional fencing. At an estimate of \$4 million per mile, the total cost of construction would amount to almost $\$ 1.5$ billion of construction.

- Mandated expanded use of the Employment Eligibility Verification System. The system must be in use by all employers for new hires 18 months after the necessary appropriations are made to fund the system, an estimated $\$ 400$ million. The bill is silent on employment verification for existing employees.

Overall, enforcement is not the essence of the Senate bill. The two key provisions in the Senate bill that would drastically impact the construction industry are amnesty for illegal immigrants and the guest worker visa program.

- Amnesty: Illegal immigrants present in the United States for more than 5 years could apply for citizenship. A modest penalty and back taxes would apply. Illegal immigrants present in the U.S. for two to five years would be allowed to remain in the U.S. without fear of deportation and apply for citizenship in three years at one of sixteen ports of entry. Illegal immigrants present for less than two years would be required to return to their nations of origin. Amnesty, therefore, would be available to approximately $85 \%$ of 
illegal immigrants. This would significantly reduce the labor shortages expected in the construction industry (Rector, 2006).

- Guest Worker Program: The Senate bill establishes the H-2C visa or "blue card." Companies would be allowed to recruit foreign workers for positions where there are a shortage of U.S. workers available. The employer would be allowed to petition the Department of Labor (DOL) for permission to hire foreign workers after they have shown reasonable effort to recruit U.S. workers. All foreign workers under this program would be paid prevailing wages. Workers would be allowed to work under this program for three years with one three-year extension. After returning to their home countries for one year, they could reapply.

Prevailing wages in this bill would be determined by the DOL wage determinations, also known as Davis-Bacon wages. Davis-Bacon wages were established by the Davis-Bacon Act of 1931. There is considerable controversy within the industry over the validity of the prevailing wage determinations made by the DOL. DOL collects data from employers in order to determine the prevailing wage. Many feel that labor unions, who offer their wage data more freely than private industry, skew the numbers toward higher union rates, and therefore, the resulting prevailing wage determination is not an accurate reflection of true prevailing wages in the region. This provision alleviates the labor shortages experienced in some construction disciplines, but makes the cost of recruiting and hiring foreign workers prohibitive. Critics predict that the prevailing wage provision in this bill would effectively promote the hiring of immigrants illegally according to market wages instead of 
inflated Davis-Bacon wages. This would counter the desired effect of the legislation to protect immigrant workers and to identify immigrants living in the U.S. for national security purposes (Sherk, 2006).

This Senate bill takes a much more lenient stance on enforcement and allows provisions for amnesty and guest workers, which would alleviate the strain on current labor resources within the construction industry.

The third bill, has taken several forms in the Senate, the first of which was introduced in the Senate on May 9, 2007; S.1348 is titled Comprehensive Immigration Reform Act of 2007. This bill failed cloture, the vote to close debate, on June 7, 2007. However, a revision of the bill was introduced on June 18, 2007, S.1639, titled Secure Borders, Economic Opportunity, and Immigration Reform Act of 2007. This bill failed cloture on June 28, 2007. The major provisions of the latest revision of the bill of particular interest to the construction industry include:

- Nominal requirement for reinforcement and the construction of fencing along the Mexican border.

- Mandated expanded use of the Employment Eligibility Verification System. The Secretary of the Department of Homeland Security (DHS) is authorized to immediately require employers working on that which the Secretary deems critical infrastructure to participate in the Employment Eligibility Verification System. The system must be in use by all employers for new hires 18 months after the date of enactment. Within three years, all employees must be verified through the system. 
- Elimination of the Diversity Visa Program.

- Amnesty: Illegal immigrants present in the United States on January 1, 2007 would be eligible to apply for a $\mathrm{Z}$ non-immigrant visa. The applicant must be able to show continuous residence since January 1, 2007 and proof of employment. A penalty would be levied for unlawful entry into the country. These immigrants would then be required to return to their consular abroad in order to submit an application for adjustment to immigrant status eligible for legal permanent residence (LPR).

- Guest Worker Program: This bill establishes the Y visa for guest workers. Companies would be allowed to recruit foreign workers for positions where there are a shortage of U.S. workers available. The employer would be allowed to petition the Department of Labor (DOL) for permission to hire foreign workers after they had shown reasonable but failed effort to recruit U.S. workers. Workers would be allowed to work under this program for 2 years with two 2-year extensions provided they were not accompanied by their families. Workers accompanied by their family members would be eligible for only one 2-year extension. After returning to their home countries for 12 months, they could reapply. Employers would be required to pay workers prevailing wages. In this bill, prevailing wages are designated as: 1) the wage governed by the collective bargaining agreement on union jobs, 2) the wage governed by Davis-Bacon wage determination on those jobs covered by the Davis-Bacon Act, or 3) prevailing wage determined by Bureau of Labor Statistics (BLS) publications. 
In contrast to DOL wage data, BLS data comes from annual surveys of employees. BLS data is the median for wages paid for the detailed occupation category. In most cases, the BLS wage is lower than the DOL wage. The following table, Table 2.3, is a comparison of BLS and DOL data for Montgomery County, Maryland, an area included in the Washington, D.C. metropolitan region. In all cases except construction laborers and construction helpers, the DOL wage is higher than the BLS wage.

Table 2.3: Comparison of Hourly Wage Data from BLS and DOL

\begin{tabular}{lll}
\hline \hline Detailed Occupation & $\begin{array}{l}\text { Davis } \\
\text { Bacon } \\
\text { Wage }\end{array}$ & $\begin{array}{l}\text { BLS } \\
\text { Wage }\end{array}$ \\
\hline Insulation workers & $\$ 30.58$ & $\$ 20.11$ \\
Roofers & $\$ 29.56$ & $\$ 16.25$ \\
Drywall installers, ceiling tile installers, and tapers & $\$ 17.44$ & $\$ 15.84$ \\
Construction helpers & $\$ 11.48$ & $\$ 11.65$ \\
Construction laborers & $\$ 11.74$ & $\$ 12.69$ \\
Brick masons, block masons, and stone masons & $\$ 22.69$ & $\$ 19.88$ \\
$\begin{array}{l}\text { Painters } \\
\text { Cement masons, concrete finishers, and terrazzo } \\
\text { workers } \\
\text { Carpet, floor, and tile installers and finishers }\end{array}$ & $\$ 29.37$ & $\$ 16.80$ \\
& $\$ 17.44$ & $\$ 16.15$ \\
& $\$ 20.76$ & $\$ 18.59$ \\
\hline
\end{tabular}

This Senate bill is even more lenient on illegal immigration than the previous bill. Under this bill, almost all illegal immigrants would be granted legal status and would be allowed continued employment.

Except for the original House bill, the immigration reform proposed by Congress will not substantially decrease the supply of immigrant labor in the United States. Employment of illegal immigrants, however, is likely to decrease as a result of 
increased scrutiny during the hiring process, mainly in the form of implementation of the Employment Eligibility Verification System. However, both of the bills proposed in the Senate convert most of the illegal immigrants currently residing in the U.S. to legal status. The prevailing wage provision mandating the use of DOL wage determinations in the Comprehensive Immigration Reform Act of 2006 was replaced with language mandating guest workers be paid prevailing wages as determined by the Bureau of Labor Statistics (BLS) or comparable data in the Secure Borders, Economic Opportunity, and Immigration Reform Act of 2007. This eliminated the artificial inflation of wages due to legislation in isolation of market demands. While the inclusion of any prevailing wage language in the legislation lends itself to interpretation and could increase wages artificially and thus induce industry inflation, this is not the intent of the legislation. While the anticipation of such inflationary effects is speculation, the critics of the legislation highlight this potential impact in order to discourage industry support of the bill (Sherk, 2006, 2007).

All three bills failed to pass into legislation. However, the national immigration debate is not over. It is an important topic in the political arena and still ranks among the top interests for voters in the 2008 elections. The construction industry is watching this political process very closely.

\subsection{Impact of Immigration on Native-Born Wages}

Fundamentally, immigration increases the supply of labor. Basic economic theory supposes that this increase in supply will adversely affect those workers for whom immigrants are direct substitutes. Many immigrants, particularly those working in the

construction industry, are unskilled laborers. Therefore, following the above 
assumption, these immigrants compete directly with native-born unskilled labor. Conversely, increased immigration has a positive impact on the complements, or other factors for which immigrants are not substitutes. For instance, the more unskilled laborers there are, the more skilled supervisors required for oversight. Therefore, assuming that most immigrant labor is unskilled, immigrant labor would complement supervisory labor, increasing the demand and the price. So, in theory, an influx of unskilled immigrant labor would decrease the wages of the unskilled nativeborn workers for which this immigrant labor is a direct substitute (The National Research Council, 1997). The question becomes by how much does the wage decrease.

Figure 2.1 is a labor market model to illustrate this concept. There are several assumptions made in order to simplify the model: 1) immigrants are perfect substitutes for unskilled native-born labor, 2) there is only one product under consideration, construction, 3) the number of native-born unskilled workers is fixed. $\mathrm{CF}$ is the demand curve for unskilled native-born workers. S represents the number of unskilled native-born workers paid wage $\mathrm{W}_{\mathrm{o}}$, the wage where supply equals demand. The rectangle OBDG is the amount that unskilled native-born workers are paid, $\mathrm{S}$ times $\mathrm{W}_{\mathrm{o}}$. Now, assume an influx of unskilled immigrant workers, I. The labor supply increases to $\mathrm{S}+\mathrm{I}$. So, the wage where supply equals demand falls to $\mathrm{W}_{\mathrm{o}}{ }^{1}$. Under the assumption that the number of unskilled native-born workers is constant, their income reduces to the area of rectangle OAKG, $\mathrm{S}$ times $\mathrm{W}_{\mathrm{o}}{ }^{1}$. Also assuming that unskilled immigrants are paid the same wage as their unskilled native-born counterparts, perfect substitutes, then the income for immigrants is represented by 
rectangle GKEH. Clearly, unskilled native-born workers are worse off due to an influx of unskilled immigrant labor for which they are perfect substitutes. By how much, then, is the difference between $\mathrm{W}_{\mathrm{o}}$ and $\mathrm{W}_{\mathrm{o}}{ }^{1}$. The slope of the demand curve will be a factor in how much the wage of the unskilled native-born worker decreases. A steep slope will decrease the wages of unskilled native-born workers more than a gradual slope.

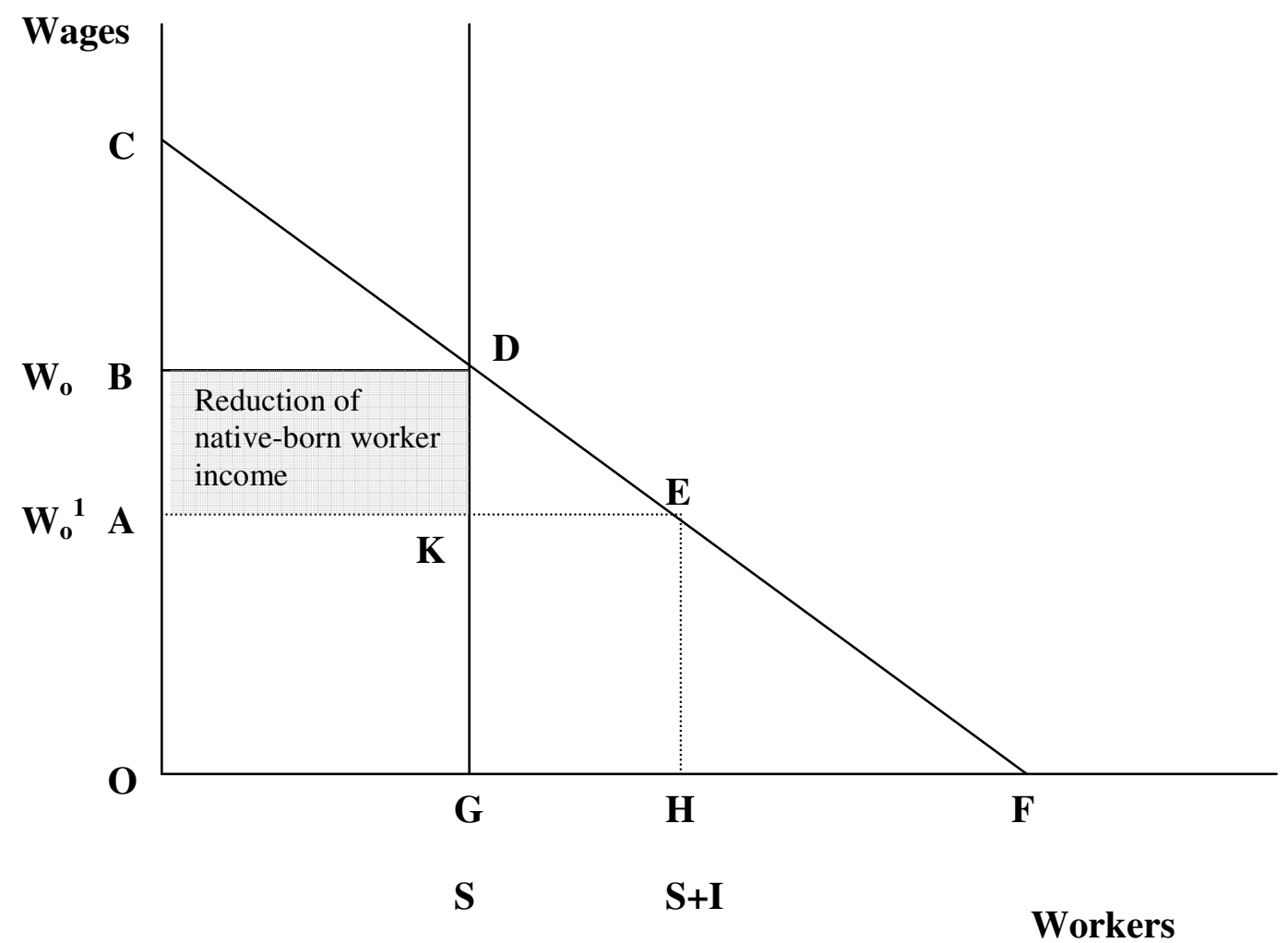

Figure 2.1 Labor Market Model (The National Research Council, 1997)

There are numerous studies that attempt to quantify this delta. The most basic study relates two elasticities, supply and demand. According to Hamermesh, the outputconstant elasticity of labor demand is approximately -0.3 (1986). Hence, a $10 \%$ increase in labor supply would reduce wages by $3 \%$. This assumes that the marginal 
cost of production is not changed by this reduction in wages. Between 1980 and 2000 immigration increased the labor supply by $11 \%$, corresponding to a $3.3 \%$ reduction in wages for native-born substitutes (Borjas, 2003). This simplified model ignores two important factors. First, the output price is not likely constant. A reduction in wages leads to a reduced cost of the output, in turn inducing another reduction in wages. Second, the $11 \%$ increase in the labor supply is a national estimate across all occupations. Since most immigrants are unskilled labor, the impact to unskilled native-born workers in low-skilled occupations such as construction will be impacted more acutely (The National Research Council, 1997).

Several studies address the impact of immigration on the wages of the native-born from the perspective of local labor markets. Immigrants tend to cluster geographically. Thus, it is supposed that the native-born workers living in areas with large influxes of immigrants will suffer a reduction in wages compared to their native-born counterparts living in regions with little immigrant-penetration. In a 1994 study, The Economics of Immigration, a comparison of the literature applying these spatial concepts is presented. The elasticity of native-born wages with respect to the number of immigrants within a geographic region in these studies tends to cluster around zero, approximately -0.01 to -0.02 . This indicates that a $10 \%$ influx of immigrants into one region as compared to another reduces the wages of the nativeborn workers in that area by about $0.2 \%$ (Borjas, 1994). Several studies relating the elasticity of native-born employment to the number of immigrants in a region also shows little impact of immigration. The elasticity of native employment also tends toward zero, ranging from -0.062 to +0.01 , indicating that a $10 \%$ increase in the 
number of immigrants in an area compared to another may reduce the employment of natives by as much as $0.6 \%$ or increase native employment up to $0.1 \%$ (Borjas, 1994). Tables 2.4 and 2.5 are summaries of this literature as presented by Borjas (1994).

Table 2.4: Elasticity of Native Wages With Respect to the Number of Immigrants Within a Region

\begin{tabular}{|c|c|c|c|}
\hline Study & $\begin{array}{c}\text { Impact of } \\
\text { Immigration } \\
\text { on: }\end{array}$ & $\begin{array}{c}\text { Dependent } \\
\text { Variable }\end{array}$ & $\begin{array}{l}\text { Elasticity } \\
\text { Estimate }\end{array}$ \\
\hline $\begin{array}{l}\text { Altonji and Card } \\
(1991, \text { p. 220) }\end{array}$ & $\begin{array}{l}\text { Less Skilled } \\
\text { Natives } \\
\text { Native } \\
\text { Mexican }\end{array}$ & $\begin{array}{l}\text { Weekly } \\
\text { Wages } \\
\text { Annual }\end{array}$ & +0.01 \\
\hline \multirow{3}{*}{$\begin{array}{l}\text { Bean, Lowell, and } \\
\text { Taylor (1988, p. } \\
\text { 44) }\end{array}$} & Men & Earnings & -0.005 to +0.05 \\
\hline & Black Men & $\begin{array}{l}\text { Annual } \\
\text { Earnings }\end{array}$ & -0.003 to +0.06 \\
\hline & $\begin{array}{l}\text { White Native } \\
\text { Men }\end{array}$ & $\begin{array}{l}\text { Annual } \\
\text { Earnings }\end{array}$ & -0.01 \\
\hline $\begin{array}{l}\text { Borjas (1990, p. } \\
87)\end{array}$ & $\begin{array}{l}\text { Black Native } \\
\text { Men }\end{array}$ & $\begin{array}{l}\text { Annual } \\
\text { Earnings }\end{array}$ & -0.02 \\
\hline \multirow[t]{2}{*}{$\begin{array}{l}\text { Grossman }(1982, \\
\text { p.600) }\end{array}$} & All Natives & $\begin{array}{l}\text { Factor share } \\
\text { of native } \\
\text { workers }\end{array}$ & -0.02 \\
\hline & $\begin{array}{l}\text { Young Black } \\
\text { Natives }\end{array}$ & $\begin{array}{l}\text { Annual } \\
\text { Earnings }\end{array}$ & -0.06 \\
\hline $\begin{array}{l}\text { LaLonde and } \\
\text { Topel (1991, } \\
\text { p.186) }\end{array}$ & $\begin{array}{l}\text { Young } \\
\text { Hispanic } \\
\text { Natives }\end{array}$ & $\begin{array}{l}\text { Annual } \\
\text { Earnings }\end{array}$ & -0.01 \\
\hline
\end{tabular}

Source: (Borjas, 1994) 
Table 2.5: Elasticity of Native Employment With Respect to the Number of Immigrants Within a Region

\begin{tabular}{|c|c|c|c|}
\hline Study & $\begin{array}{c}\text { Impact of } \\
\text { Immigration } \\
\text { on: }\end{array}$ & Dependent Variable & $\begin{array}{l}\text { Elasticity } \\
\text { Estimate }\end{array}$ \\
\hline \multirow{3}{*}{$\begin{array}{l}\text { Altonji and Card } \\
(1991, \text { p. 220) }\end{array}$} & & $\begin{array}{l}\text { Employment-population } \\
\text { ratio }\end{array}$ & -0.038 \\
\hline & $\begin{array}{l}\text { Less Skilled } \\
\text { Natives }\end{array}$ & Weeks Worked & -0.062 \\
\hline & $\begin{array}{l}\text { White Native } \\
\text { Men }\end{array}$ & $\begin{array}{l}\text { Labor force participation } \\
\text { rate }\end{array}$ & -0.01 \\
\hline $\begin{array}{l}\text { Borjas }(1990, \mathrm{p} . \\
92)\end{array}$ & $\begin{array}{l}\text { Black Native } \\
\text { Men }\end{array}$ & $\begin{array}{l}\text { Labor force participation } \\
\text { rate }\end{array}$ & +0.04 \\
\hline $\begin{array}{l}\text { Muller and } \\
\text { Espenshade (1985, } \\
\text { p. 100) }\end{array}$ & $\begin{array}{l}\text { Black } \\
\text { Natives }\end{array}$ & Unemployment rate & -0.01 \\
\hline \multirow[t]{2}{*}{$\begin{array}{l}\text { Simon, Moore, and } \\
\text { Sullivan (1993) }\end{array}$} & Natives & Unemployment rate & +0.001 \\
\hline & $\begin{array}{l}\text { Young White } \\
\text { Natives }\end{array}$ & Unemployment rate & +0.01 \\
\hline $\begin{array}{l}\text { Winegarden and } \\
\text { Khor }(1991, \mathrm{p} \text {. } \\
109)\end{array}$ & $\begin{array}{l}\text { Young Black } \\
\text { Natives }\end{array}$ & Unemployment rate & -0.003 \\
\hline
\end{tabular}

Source: (Borjas, 1994)

In particular, the Card study, The Impact of the Mariel Boatlift on the Miami Labor Market, found that the $7 \%$ increase in the immigrant population as a result of the Mariel Boatlift from Cuba had negligible impact on the labor market performance of native-born workers. The Mariel Boatlift refers to the mass immigration of over 125,000 Cubans from the port of Mariel, Cuba to Miami and other Florida ports between April and October 1980. On the urging of Cuban dictator Fidel Castro and because of deteriorating economic and political conditions in Cuba, thousands of 
Cuban nationals left Cuba in boats chartered by Cuban-Americans who were attempting to rescue their Cuban relatives and friends. This mass exodus increased the immigrant population of Miami by almost 7\% in only a few months (Card, 1990).

An extensive study conducted by the National Research Council in 1997 showed only a weak correspondence between native-born worker wages and the supply of immigrants in a confined geographic area. However, the study did conclude that wages of high school dropouts decreased by about 5\% between 1980 and 1994 as a result of this portion of the population being in direct competition for employment with the majority of immigrants who also have low-educational attainment (The National Research Council, 1997).

Even research on international labor markets using spatially correlated methods concludes there is little impact on native-born worker wages. The report, The Impact of Immigration on Host Country Wages, Employment, and Growth found negligible impact on the Israeli labor market from mass immigration (Friedberg and Hunt, 1995).

There are noted problems with research that approaches the impact of immigration on native-born workers' employment and wages in terms of geography. Spatial approaches isolate high-immigrant, geographic areas as discrete, closed labor markets. They ignore other indicators within the economy that tend to equalize conditions across regions. There is also an assumption in spatially correlated research that the flow of immigrants into a region is exogenous. This methodology excludes effects of internal migration of immigrants and of native-born workers and also 
excludes the effects from decisions of immigrants and native-born workers not to migrate to immigrant-saturated regions (Camarota, 1997; Borjas, 2003, 2006).

The flow of labor, capital, and goods across geographic regions tends to equalize the wage rate. So, as long as native-born workers respond to influxes of immigrants into a region by moving to areas with better opportunities or by not moving into immigrant-saturated regions, then the impact of immigration on native-born wages is masked in these spatially correlated studies.

More recent research uses a factor-proportions approach. This approach purports that a national perspective rather than a geographically localized perspective is needed because the impact of immigration on native-born worker market opportunities operates in the aggregate economy rather than in an isolated locality. Additionally, these studies consider the concentration of immigrants within certain skill groups. Immigrants expand the supply of unskilled skill groups over skilled labor, thereby changing the factor proportions in the economy. These studies find that immigration tends to depress wages across the economy as a whole, impacting the low-skilled occupations more severely than skilled or professional occupations (The National Research Council, 1997).

In the study, Labor Market Effects of Immigration and Trade, researchers found that the increase in the low-skilled labor force due to immigration and trade accounted for over $40 \%$ of the decline in relative earnings of high school dropouts in the 1980's. The trade factor is related to the decline of low-skilled jobs available in the U.S. as a result of importing goods that directly compete with domestic low-skilled manufacturing jobs, thus impacting the demand of low-skilled native-born workers, 
(Borjas, et.al., 1993). This broader view of the impact of immigration on the labor market shows markedly increased impacts from previous spatial studies. Spatial studies also tend to obscure the impact of immigration on local economies because immigrants are attracted to geographic areas with economic growth. Both immigrant and native-born worker migration patterns are affected by economic conditions, thus creating a national economic equilibrium (Camarota, 1997).

The factor-proportions approach is also supported by research that shows immigration and economic factors influence migration patterns of native-born workers. As evidence, the Mariel Boatlift that increased the population of Miami by $7 \%$ in just a few months did not affect the growth rate of Miami as compared to the rest of Florida. This suggests that the migration rate of natives and other immigration into Miami slowed considerably in response to the boatlift and the decreased economic opportunity (Card, 1990). Frey also finds evidence that migration of natives is linked to immigration from abroad $(1994,1995)$. His research found that, with the exception of California, states that showed the highest immigration from abroad also showed very high rates of out-migration. Additionally, this out-migration is not limited to the well-educated, but to low-income and middle-income earners as well (Frey, 1994, 1995).

There are also several studies that contradict the assertion that immigration leads to out-migration of natives from a region. In the study, Immigration and Wages: Evidence from the 1980's, Butcher and Card find that immigration had no impact on native outflow. Using Census data from 1970, 1980, and 1990, Card and DiNardo also found negligible impact on out-migration of native-born workers in a particular 
skill-group compared to the inflow of immigrants with similar skills (2000). However, these studies do not account for the decision of immigrants and native-born workers not to migrate to immigrant-saturated regions. Additionally, this research ignores other economic factors relating to immigration decisions, like economic growth in a region which attracts immigrant and native-born workers.

The most recent study on the national impact of immigration on the wages of nativeborn workers shows a reduction in the weekly earnings of native-born workers of 4.9\% on average. This study finds a more substantial reduction for high school dropouts between 1980 and 2000. From our survey results, this population more closely resembles the construction workers, particularly those detailed occupations with high immigrant-labor penetration, as 75\% reported not finishing high school and $43 \%$ report an education level of $6^{\text {th }}$ grade or less (Borjas, 2003).

The study uses a linear regression model with the log of weekly earnings of nativeborn workers as the dependent variable and the percent immigration within a skill group as the independent variable. Skill groups are defined as a combination of education and working experience. The findings show that for high school dropouts, the reduction in wages range from a high of $12.7 \%$ to a low of $1.8 \%$, with an average of $7.4 \%$ reduction across all skill levels depending on work experience. The highest reductions are estimated for those with 11-20 years of experience. Decennial census data from 1960-2000 were used in this study (Borjas, 2004). A counterfactual model simulation predicting wage impact without immigration found a reduction in weekly earnings of high school dropouts of $0.2 \%$ for the same time period (Borjas, 2004). 
A previous study, The Effect of Immigrants on Low-Skilled Native Workers: Evidence from the 1991 Current Population Survey, found remarkably similar results using only education as a modifier for a particular group. This study also used a linear regression model in order to define the relationship between earned wages and percent immigrant penetration within an occupation. For low-skilled occupations, those requiring only a high school diploma or less, the study found a $0.7 \%$ reduction in weekly earnings of native-born workers for every $1 \%$ increase in immigration within the occupation. The dependent variable in this model was the log of the weekly earnings, and the independent variable was the percentage of immigrants within the occupation. With an estimate of immigrants in these low-skilled occupations between 15 and 19 percent, the estimate of wage reduction expected for native-born workers in these same occupations is between 10.5 and 13 percent. The data for this study were taken from the 1991 CPS (Camarota, 1997). The common factors among these reports were the national context of the research and the consideration of the proportions of immigrants by education and/or skill level (Camarota, 1997, Borjas, 2003).

Curtailing immigration will certainly cause an increase in wages from the currently depressed wages, but the market will not likely stand an increase on this order. Rather, a combination of wage increase and technology increase will likely make up this difference. There are several labor-saving processes and devices already on the global market that may be adopted within the U.S. construction industry.

Analysis of the Malaysian market offers interesting insight into the reaction of the construction industry to immigration over time. In the late 1970's and early 1980's, 
Malaysia experienced a boom in construction. Upward adjustment of wages and working conditions within the construction industry did not materialize correspondingly with the economic growth nationally. Natives were drawn to other markets. When the local labor market did not respond sufficiently, illegal immigrants were substituted. During the subsequent recession, native workers exited the local construction sector almost completely and migrated to East Asian countries with more healthy markets. Since then, immigrant workers have increased in the Malaysian construction sector, which now accounts for more than 70 percent. As a result of immigrant substitutions artificially depressing wages, construction wages have not kept pace with growing wages in other markets. The upward adjustment necessary to attract local workers is now out of reach of the industry. The Malaysian government responded repeatedly over the last decade to illegal immigration, through increased fines for hiring illegal immigrants, deportation of illegal immigrants, and mandatory wage equality between native workers and immigrants. Their efforts have not been sufficient to attract local workers back to the industry, and many Malaysian construction workers choose to work abroad illegally in Singapore, Japan, and Taiwan for higher wages and better working conditions (Narayanan and Lai, 2005).

\subsection{Literature Review Conclusions}

In summary, the literature on immigration is extensive. The illegal population residing in the U.S. is estimated to be approximately 11 million. There has been tremendous debate in Congress involving immigration and immigration policy reform. No new policy has been enacted, but there remains constant attention on the issue of immigration across the U.S. Legislation may spur a labor shortage in 
construction, but not likely as a result of mass deportation of illegal immigrants. It is more probable that labor shortages would erupt as a result of more stringent employment verification requirements that make it more difficult for illegal immigrants to gain employment using fraudulent documentation.

There is considerable research available on the impact of immigration on the wages of native-born workers. While some of it is conflicting, there is recent convergence on the notion that immigration has an impact nationally on wages, which is not drastically noticeable in local economies. This is largely a result of internal migration patterns of immigrants and native-born workers resulting in national economic equilibrium and the disproportionate number of immigrants in the low-skilled occupations. The national impact on wages is significant and on the order of a $4.9 \%$ decrease in average weekly earnings for native-born workers across all skill levels. This impact is more pronounced on low-skilled workers, approximately $11 \%$.

The literature is largely silent on the impact of immigration specifically focused on construction project costs, which is the aim of the proposed research. 


\section{Chapter 3: The Survey}

\subsection{The Survey Instrument}

In order to evaluate the impact on project costs, first, an estimate the number of illegal immigrant workers on the project is required. As mentioned previously, much of the data on foreign-born workers in the United States come from the decennial census or the annual Current Population Survey (CPS), both conducted by the Census Bureau. The CPS includes analysis on poverty, income, welfare use, health insurance coverage, educational attainment, and other social and economic factors. The March CPS includes a large sample of minorities and is relied upon heavily in national estimates of the immigrant population. Geographically localized estimates of the immigrant population are available in a broad sense, but lacking from the data are localized estimates by detailed occupation. The Census and CPS have produced data on immigrant workers by detailed occupation nationally. Consequently, these data minimize the impact of immigration and immigration reform in areas where immigrants tend to cluster, hereafter referred to as immigrant-saturated regions like the Washington, D.C. metropolitan area. Hence, the first stage of this research attempts to estimate the number of illegal construction workers in the Washington, D.C. metropolitan area. This information is crucial to the construction industry as national estimates can not be realistically relied upon in immigrant-saturated regions. This estimate is important to the cost of construction projects because it is this population of workers that will be affected by immigration reform legislation. Moreover, should employment verification be made more stringent either by 
legislation or enforcement of existing laws, employment availability of this vast supply of illegal workers will dissipate.

Initially, this research was sponsored by a major construction company in the Washington, D.C. metropolitan area. Their interest lay specifically with the effect of immigration reform on their labor supply and costs. The company was a large concrete subcontractor in the area, a subsidiary of a large general contractor operating nationally. In order to properly analyze the impact of immigration reform for this organization, a survey was created and implemented in order to estimate the number of illegal and legal immigrant workers employed on company project sites.

Few surveys have been undertaken to specifically isolate the illegal immigrant population. Most information on illegal immigrants in the workforce has been generated from Census Bureau data, as discussed above. A residual method of estimation is often used, whereby the number of known legal immigrants is subtracted from the total immigrant population, yielding an estimate of the number of illegal immigrants. Through this method, the estimate of illegal immigrants includes the "quasi-legal" immigrants as well as the undocumented, truly illegal immigrants. Since regional estimates are not broken down into detailed occupation groups due to inadequate regional sample sizes, these estimates are not reasonable for immigrantsaturated trades in immigrant-saturated regions. The estimate of illegal immigrants working in these trades in immigrant-saturated regions is expected to far exceed these national estimates.

Without relying on this type of residual method of estimation, a direct method of estimation would be most appropriate. However, illegal workers have a vested 
interest in lying or avoiding questions related to immigration status, making a direct survey method impossible. Thus, an indirect method of questioning is necessary in order to generate accurate estimates of illegal immigrant workers.

One method of indirectly identifying illegal immigrants through a survey is the "TwoCard Method," pioneered by the U.S. Government Accountability Office (GAO) in 1998 (Government Accountability Office, 1999). Using this survey method, respondents are shown one of the cards in Figure 3.1; a random half of the sample is shown card 1 , and the other half is shown card 2.

\section{CARD 1}

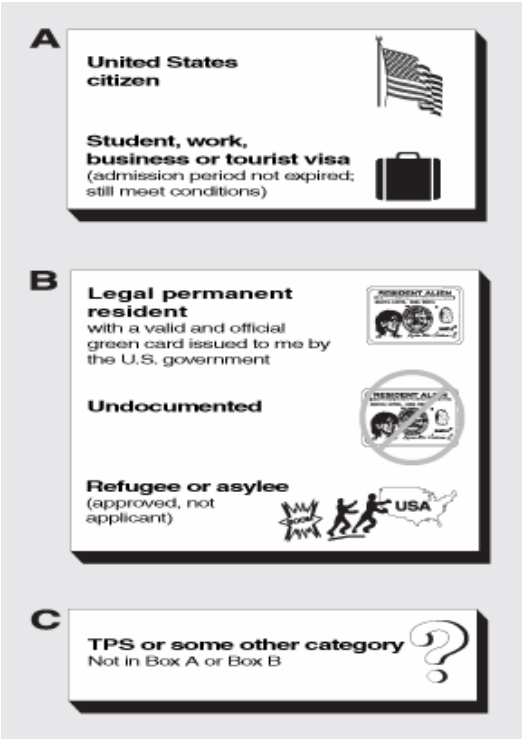

CARD 2

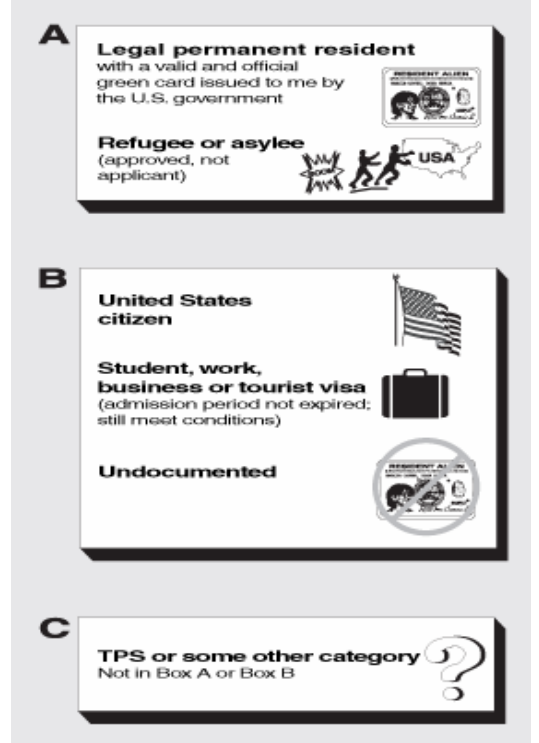

\section{Figure 3.1: Immigration Status Cards}

Respondents are asked to pick the box that includes their current immigration status. They are told not to pick specific categories within the box, just the letter A, B, or C corresponding to the box that contains their current immigration status. The percentage of illegal immigrants is calculated by subtracting the percentage that 
picked Box A from one card from the percentage that picked Box B from the other card and adding the percentage that picked box $\mathrm{C}$ from either card. This estimate includes the truly undocumented or illegal immigrants and those with "quasi-legal" status. Both categories are affected by immigration reform and therefore, both categories are relevant to this research. The number of truly undocumented or illegal immigrants can be calculated by subtracting Box A from Box B, without adding Box C.

The basic logic behind the "Two-Card Method" is as follows. The total sample is chosen such that half of the sample is sufficient in order to generate statistically sound estimates. Half of the sample is shown card 1, and the other half of the sample is shown card 2. The half of the sample that is shown card 1 is used to estimate those respondents that are United States citizens or are present in the U.S. on a valid student, work, business, or tourist visa, i.e. those that pick Box A from card 1. The half of the sample that is shown card 2 is used to estimate those respondents that are United States citizens, are present in the U.S. on a valid student, work, business, or tourist visa, or are undocumented immigrants, i.e. those that pick Box B. "Quasilegal" immigrants, those that are present in the U.S. through a Temporary Protected Status, those eligible for the Deferred Enforced Departure (DED) program, Nicaraguan and Central American Relief Act beneficiaries, asylum applicants, fiancé, spouse, or child visa applicants - known as adjustment applicants, and Legal Immigrant Family Equity Act (LIFE) section 245(i) beneficiaries are estimated from those that choose Box $\mathrm{C}$ from either card 1 or card 2. The percentage of illegal immigrants, then, is calculated by subtracting the estimate of United States citizens 
and those present in the U.S. on a valid student, work, business, or tourist visa, those that picked Box A from card 1, from the estimate of United States citizens, those present in the U.S. on a valid student, work, business, or tourist visa, and undocumented immigrants, those that picked Box B from card 2, plus the estimate of "quasi-legal" immigrants, those that picked box $\mathrm{C}$ from either card. The number of truly undocumented immigrants can be calculated by subtracting Box A -card 1 from Box B-card 2, without adding Box C-card 1 or card 2.

Alternatively, the half of the sample that is shown card 2 may also be used to estimate those respondents that are Legal Permanent Residents (LPRs) and those that are present in the U.S. under an approved refugee or asylee status, i.e. those that pick Box A from card 2. The half of the sample that is shown card 1 may be used to estimate those respondents that are Legal Permanent Residents (LPRs), those that are present in the U.S. under an approved refugee or asylee status, and those that are undocumented immigrants, i.e. those that pick Box B from card 1. Again, "quasilegal" immigrants may be estimated from those that choose Box C from either card 1 or card 2. Then, the percentage of illegal immigrants would be calculated by subtracting the estimate of Legal Permanent Residents (LPRs) and those that are present in the U.S. under an approved refugee or asylee status, those that picked Box A from card 2, from the estimate of Legal Permanent Residents (LPRs), those that are present in the U.S. under an approved refugee or asylee status, and those that are undocumented immigrants, those that picked Box B from card 1, plus the estimate of "quasi-legal" immigrants, those that picked box $\mathrm{C}$ from either card. The number of 
truly undocumented immigrants is still calculated by subtracting Box A - card 2 from Box B - card 1, without adding Box $\mathrm{C}-$ card 1 or card 2.

Because the total sample is sufficient for half of the sample to produce statistically relevant estimates, it will not matter whether the Box A estimate from card 1 is subtracted from the Box B estimate from card 2 or the Box A estimate from card 2 is subtracted from the Box B estimate from card 1. Both calculations should reveal similar results (Government Accountability Office, 1999).

GAO originally devised this method for the purpose of surveying the foreign-born regarding immigration status. There are five mutually exclusive, exhaustive categories for immigrants: legal permanent residents (LPR) with valid green card, refugees and asylees (persons granted asylum), persons admitted temporarily who stay legally for more than a year, naturalized U.S. citizens, and illegal or undocumented immigrants. Recall that this survey method requires two representative samples of the population of interest; one is shown card 1 and the other card 2. The sensitive category of undocumented is presented with two less sensitive categories in Box B. If respondents choose Box B, no further inquiry is made. If respondents choose Box A, which is composed of 2 less sensitive categories of immigration status, several follow-up questions are asked to be sure that the respondent has chosen Box A correctly. The follow-up questions include asking under which program they received their legal status, country of origin, year of entry, and year they acquired legal status. Box $\mathrm{C}$ is comprised of a less-sensitive and rare category among the sample. If respondents choose Box C, several follow-up questions are asked as well to ensure that respondents have chosen the correct 
category. The cards are arranged so that Box A from card 1 contains the same two less sensitive categories of immigration status appearing with the sensitive category of undocumented in Box B of card 2 (GAO, 1999, 2006).

Recent field studies conducted by GAO and evaluated independently proved the "Two-Card Method" an acceptable method for interviewing immigrants and found the results to be reliable. Limitations of this method include the necessity to conduct the survey via in-person interview and the large sample required to obtain accurate estimates. Approximately 2,000 respondents are needed for an estimate of the percentage undocumented with a $90 \%$ confidence interval of plus or minus 4 percentage points, assuming $50 \%$ of the respondents are undocumented. If the assumption is that only $30 \%$ of the population of interest is undocumented, then 2,500 survey respondents are required for the same confidence interval (GAO, 2006).

Another method used in direct survey of the foreign-born for the express purpose of determining immigration status is the Residency Status Assignment based on answers to a series of questions. This method was established by Dr. Enrico Marcelli of Harvard University (Figure 3.2). 


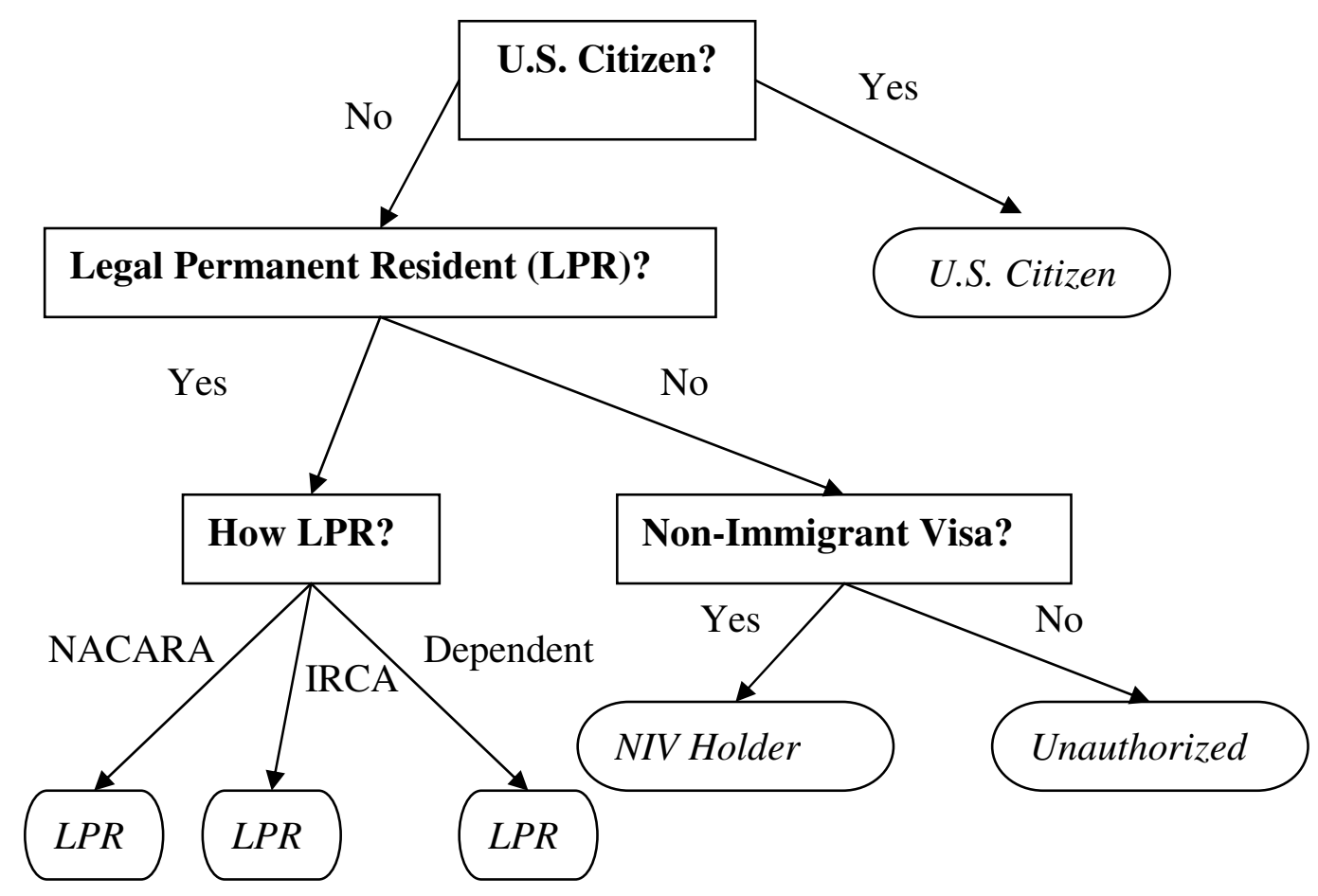

Figure 3.2: Residency Status Assignment (adapted from Marcelli and Lowell, 2005)

This methodology assigns a residency status to the respondent based on answers to a series of questions. While the question of being undocumented is never asked outright, the status of immigration is implied by the answers to these questions. IRCA Legalization refers to the Immigration Reform and Control Act of 1986. This act made it illegal to knowingly hire or recruit illegal immigrants for the first time. There was also an amnesty provision for illegal immigrants included in the act under two programs: Legally Authorized Worker (LAW) and Special Agricultural Worker (SAW). Under the LAW program, illegal immigrants who had lived in the U.S. since January, 1982 could become temporary legal residents and after 18 months could apply for LPR status provided they met certain criteria such as basic knowledge of the English language. Under the SAW program, illegal immigrants must have worked 
for at least 90 days in each of the three previous years or at least 90 days in the last year in order to qualify for temporary resident status. SAW applicants could apply for LPR status after one or two years. Over 3 million illegal immigrants were granted residency under these two programs (Orrenius and Zavodny, 2001). In order to identify those that may misrepresent their true immigration status in answering these questions, additional questions may be added to ensure the validity of the answers. For example, year of entry into the United States will determine eligibility for the IRCA program.

A survey was crafted using these 2 methods of estimation in order to determine the percentage of illegal immigrants employed by the company that initially sponsored this research, Appendix A. While the company insisted that all of their employees had been properly screened for employment by completing the government mandated Employment Eligibility Form, the I-9 form, research predicts that one-third of immigrant documentation is fraudulent (Camarota, 2005).

The I-9 form was implemented with the IRCA legislation in 1986, which required employers to verify employment eligibility by a review of authorized documentation provided by the prospective employee. Employers are required to complete and retain the I-9 form for every employee, regardless of citizenship or national origin. Section 1 of the form, Employee Information and Verification, must be completed by the employee at the time of employment. Employers are responsible for deficiencies in Section 1, but are not allowed to demand proof of the validity of that information. Information required in Section 1 includes name, address, date of birth, Social 
Security Number, and citizenship status. If a translator is used, the translator must also sign and certify Section 1 .

Section 2 of the form, Employer Review and Verification, must be completed by the close of business on the third day of employment. The employer must review and verify the original documentation presented by the employee in order to establish identity and work authorization. The employer must accept the document submitted if it is on the list of acceptable documents, the documentation reasonably appears genuine, and the documentation relates to the person presenting the documentation, i.e. the picture on the document is of the person presenting them. Employers may reject documents that appear fraudulent and ask for other documentation. Employers are not required to keep copies of documentation on file with the I-9 forms. Employees who can not produce documentation to satisfy Section 2 must be terminated. Section 3, Updating and Reverification, must be completed by the employer by the date that employment authorization expires.

Upon request, all I-9 forms must be made available to representatives of the Department of Homeland Security (DHS), Department of Labor (DOL), or the Office of Special Counsel for Unfair Immigration-Related Employment Practices of the Department of Justice (DOJ). Failing to comply with the I-9 requirements may result in penalties of not less than $\$ 110$ and not more than $\$ 1,100$ for each employee for whom the I-9 was not properly completed or retained. Penalties for knowingly hiring or continuing to employ unauthorized workers are not less than $\$ 275$ and not more than $\$ 2,200$ for each unauthorized employee for the first offense, not less than $\$ 2,200$ and not more than $\$ 5,500$ for each unauthorized employee for the second offense, and 
not less than $\$ 3,300$ and not more than $\$ 11,000$ for each unauthorized employee for the third offense (Buffett, 2007).

In developing the survey, the Residency Status Assignment method was adapted by adding such LPR options as Nicaraguan Adjustment and Central American Relief Act (NACARA), Dependent or Family Member, and work sponsor. NACARA benefits apply to Guatemalans, Nicaraguans, Cubans, Salvadorans, and nationals of former Soviet bloc countries and their dependents. Nicaraguans and Cubans may apply for LPR status under this program provided they show evidence of continual presence in the U.S. since December 1, 1995. Guatemalans must have been physically present in the U.S. since October 1, 1990 and file for asylum with U.S. Citizenship and Immigration Services (USCIS) on or before January 3, 1995. Salvadorans must have been physically present in the U.S. since September 19, 1990 and file for asylum with the USCIS on or before February 16, 1996. Nationals of former Soviet bloc countries must have entered the country on or before December 31, 1990 and filed for asylum on or before December 31, 1991 (www.uscis.gov). If the respondent to the survey affirmed LPR status, his eligibility was established by comparison of his immigration circumstances (country of birth and year of immigration) with the current law.

\subsection{Implementing the Survey}

The survey was administered to 896 construction workers on projects of the company sponsoring the research between the time period of September 2006 and February 2007. Sixty-six surveys were discarded due to incomplete information. All surveys were voluntary and anonymous; names, addresses, or other personal information were not collected. An advocate from the company was present and participated in the 
interview process in order to reassure the employees of the authenticity and anonymity of the survey. The data from the surveys were compiled and presented to the company on May 24, 2007 (Golden and Skibniewski, 2007a). The survey covered 11 projects in Washington, D.C., Montgomery and Prince Georges Counties, Maryland, and Loudoun and Fairfax Counties, Virginia (see Table 3.1).

\section{Table 3.1: Participating Projects}

\begin{tabular}{|c|c|c|c|}
\hline \multirow{2}{*}{$\begin{array}{l}\text { Project } \\
\text { Government Administrative }\end{array}$} & \multirow[t]{2}{*}{$\begin{array}{c}\text { Workers } \\
\text { Interviewed }\end{array}$} & \multicolumn{2}{|c|}{ Date } \\
\hline & & & \\
\hline Facility, White Oak, MD & 27 & 14-Sep-06 & \\
\hline High-rise Office Building, & & & \\
\hline Arlington, VA & 146 & 24-Oct-06 & 3-Nov-06 \\
\hline $\begin{array}{l}\text { High-rise Office Building, Rosslyn, } \\
\text { VA }\end{array}$ & 133 & 26-Oct-06 & 27-Oct-06 \\
\hline High-rise Office Building, New & & & \\
\hline $\begin{array}{l}\text { York Ave, Washington, D.C. } \\
\text { High-rise Office Building, }\end{array}$ & 148 & 01-Nov-06 & \\
\hline Arlington, VA & 77 & 15-Nov-06 & \\
\hline Stadium, Washington, D.C. & 95 & 16-Nov-07 & \\
\hline High-rise Office Building, & & & \\
\hline Manassass, VA & 31 & 12-Dec-06 & \\
\hline Mall, Washington, D.C. & 47 & 18-Jan-07 & \\
\hline High-rise Office Building, 3rd & & & \\
\hline Street, Washington, D.C. & 35 & 24-Jan-07 & \\
\hline Airport, Dulles, VA & 76 & 16-Feb-07 & \\
\hline Equipment Yard, Clinton, MD & 15 & 22-Feb-07 & \\
\hline
\end{tabular}

In consideration of work flow and in an effort to minimize disruption to ongoing construction activities, the surveys were conducted in the field. Conditions for administering the survey were arduous. The survey was administered using makeshift tables near the crews. Groups of 4-6 employees were interviewed at a time. The purpose of the survey was explained to be part of a construction industry labor resources research project at the University of Maryland in both English and Spanish 
languages. The participants were promised that the survey would remain anonymous. Employees were also notified that participation in the survey did not affect employment or immigration status. The primary purpose of this research was noted as educational and results were promised to remain confidential.

Due to the dismal literacy rate among employees, most of the surveys were administered personally to groups of 1-2 employees at a time. Illiteracy was not anticipated to be as prevalent as was discovered. This significantly slowed the survey progress, as generally no more than 50 employees could be interviewed in a day.

Although not anticipated, this is not a new issue among immigrants. The 1976 study The Characteristics and Role of Illegal Aliens in the U.S. Labor Market: An Exploratory Study by North and Houston reported similar difficulty in conducting surveys with immigrants. “[It] was our subjects' lack of education, informal as well as formal, which rendered the collection of useful data particularly difficult."

The non-response rate was particularly low. Very few workers refused the interview, less than 5 out of the almost 900 surveys. This is likely due to a variety of factors including 1) the survey seemed non-threatening, presenting from an educational authority and not from a government agency, 2) the advocate from the company and community helped gain the trust of the respondents, even those outside of the company, and 3) for employees of the company sponsoring the research, they may have felt they could not refuse the survey, even though the survey was presented as voluntary, anonymous, and having no bearing on immigration or employment status. However, some of the questions from the surveys were left blank. Some of them were probably omitted due to a lack of understanding of the question or a lack of 
literacy, and some were likely left blank out of refusal to answer the question. There were a few instances of respondents refusing to give their hourly wage because they did not want their counterparts knowing how much they made. Most of the respondents answered most of the questions. In cases where the residency status could not reasonably be determined based on the answers or lack of answers to the questions, the survey was discarded. In cases where residency status could be reasonably assigned based on the survey, but other information was left blank, the survey was included. However, for the compilation of the characteristics from the data, for instance average hourly wage, blanks were not included in the calculation. Some respondents admitted their illegal status willingly and even circled the undocumented category in box B from the "Two Card Method." A few respondents asked to consult their green card or work authorization card in order to answer basic demographic information, like date of birth. This hinted of an illegal status, which was in most cases confirmed by their answers to the Residency Assignment questions.

Table 3.2 shows the breakdown of occupations surveyed. 
Table 3.2: Participating Trades in On-Site

Survey

\begin{tabular}{lc}
\hline \hline Trade & $\begin{array}{c}\text { Workers } \\
\text { Interviewed }\end{array}$ \\
\hline Brick Masons & 12 \\
Carpenters & 377 \\
Concrete & \\
Masons/Finishers & 27 \\
Construction Laborers & 260 \\
Helpers & 12 \\
Steel Worker (Rebar) & 50 \\
Supervisors & 59 \\
Unknown & 33 \\
\hline Total & 830 \\
\hline
\end{tabular}

\subsection{Characteristics of the Workforce}

\subsubsection{Immigration Status}

The Residency Status Assignment Method revealed 55.4\% undocumented and "quasilegal" workers and approximately $22.41 \%$ truly undocumented workers. As was suspected, these numbers are far greater than national averages and compound the immigration effect on worker wages and subsequently, construction project costs in the region (Golden and Skibniewski, 2008c).

The sampling strategy employed does not produce a representative sample of the illegal immigrant population in the construction industry workforce and therefore, does not produce statistically sound results outside of the company ranks from which the survey was administered. However, the study and data are not irrelevant. Random selection of immigrant construction workers across the region is not possible. Immigrant workers were not cooperative without an advocate present to 
reassure the respondent that the survey was in fact anonymous. Additionally, many contractors were not interested in their workers participating in the survey. Data gathering first involved persuading the cooperation from the employer and then the cooperation of the employee, which precluded a random sample of immigrant workers.

Extrapolation of the quantitative survey results to the universe of construction workers in the Washington, D.C. metropolitan region requires judgment. The results are not valid for other regions because the concentration of immigrants varies geographically. However, the survey methodology is transferable and may be used outside of the Washington, D.C. metropolitan area for assessment of immigrant populations elsewhere.

The impossibility of statistically valid estimates has likely contributed to the lack of research in this area. This void of research has led to very broad speculation regarding the impact of immigration reform policy on the construction industry. So, even though not statistically relevant, this research is important in order to establish some basis for industry response to the research questions addressed in this research. It is the first such research within the construction industry to present empirical data on the impact of immigration on construction project costs.

Where similarities can be found between this company and other companies and between these projects and other commercial construction projects, inferences about the characteristics of the total immigrant workforce in construction in the Washington, D.C. metropolitan area may be drawn. The characteristics of this company's workforce are likely similar to other companies with similar hiring 
practices, working in commercial construction on similar-sized projects. This company's hiring practices are common across the construction industry. An advocate from the Hispanic community was hired to assist with recruiting and retention. This community liaison assists workers with I-9 forms, immigration issues such as worker authorization, tax forms and withholdings, and other such human resources functions. Several other companies contacted have similar procedures and positions in place. In order to ensure the availability of their cheaper immigrant workforce, companies assist workers with worker authorization, residency and worker authorization renewals, and other uniquely immigrant issues. The community liaison also assists the company in overcoming other cultural barriers such as language. Many of the connections for employment for these immigrant workers come from referrals of family or friends. This is common across immigrant communities and also affects immigrant migration patterns. Several studies document that social networks encourage immigration by mitigating the risk associated with immigration through decreased costs, contacts for employment, and transfer of information for things like housing (Gurak and Caces, 1992; Massey and España, 1987; Palloni, et. al., 2001).

The immigrant construction worker characteristics gleaned from this study are also likely similar to other construction workforces in low-skilled occupations, like those immigrant-saturated trades. Immigrant-saturated trades have been identified in this research as construction trades in which the illegal immigrant share of the trade population is greater than $20 \%$ according to national estimates. These trades include insulation, roofing, drywall, masonry, painting, concrete, and flooring (Passel, 2006). 
The data are statistically relevant for the company sponsoring the research. There were 719 viable surveys administered to company employees from a pool of 1,300 workers employed by the company for the time period of the survey. The other 111 viable surveys were administered with company permission on their construction projects to subcontractor employees. The same survey methods were used for both groups of employees (Golden and Skibniewski, 2007a).

Thus, for this research, in line with the results of the survey, an illegal immigrant population of $55 \%$ is assumed in the immigrant-saturated, low-skilled occupations listed above and identified in Table 2.1.

Before examining the impact of this group on construction projects costs, it is instructive to examine some basic demographic information.

\subsubsection{Country of Birth}

Approximately $70 \%$ of respondents were born in El Salvador. Only $4.83 \%$ reported being born in Mexico. Another $11.76 \%$ reported being born in another Latin American country, with Honduras ranking second to El Salvador. Table 3.3 shows the breakdown of respondents by country of birth. There were 808 respondents to this question. 


\begin{tabular}{lcc}
\hline \multicolumn{3}{c}{ Table 3.3: Country of Birth } \\
\hline \hline \multicolumn{1}{c}{ Country } & $\begin{array}{c}\text { Number of } \\
\text { Respondents }\end{array}$ & Percentage \\
\hline El Salvador & 572 & $70.79 \%$ \\
U.S. & 75 & $9.28 \%$ \\
Honduras & 70 & $8.66 \%$ \\
Mexico & 39 & $4.83 \%$ \\
Guatemala & 21 & $2.60 \%$ \\
Dominican & & \\
Republic & 7 & $0.87 \%$ \\
Bolivia & 5 & $0.62 \%$ \\
Jamaica & 4 & $0.50 \%$ \\
Nicaragua & 4 & $0.50 \%$ \\
Peru & 3 & $0.37 \%$ \\
Trinidad and & & \\
Tobago & 3 & $0.37 \%$ \\
Columbia & 2 & $0.25 \%$ \\
Burkina Faso & 1 & $0.12 \%$ \\
Ecuador & 1 & $0.12 \%$ \\
Ghana & 1 & $0.12 \%$ \\
\hline Total & $\mathbf{8 0 8}$ & \\
& & \\
\hline
\end{tabular}

The heavy concentration of Salvadorans was not surprising. The U.S. census reports more than 1,000,000 Salvadorans currently reside in the U.S., with 133,000 in the Washington, D.C. metropolitan area. Salvadorans are the largest immigrant group in this area. The Salvadoran Embassy reports that when U.S. born children of Salvadorans are counted, the population of Salvadorans living in the U.S. increases to $1,700,000$ with about 500,000 of those residing in the Washington, D.C. metropolitan area (Aizenman, 2007 and www.census.gov). Since this research does not focus on immigrants from one country or region, while interesting, this anomaly does not affect the outcomes of the research (Golden and Skibniewski, 2008c). 


\subsubsection{Age}

The average age of the respondents was 37 years; the average age of the illegal immigrant respondents was 34 years. Figure 3.3 shows the age distribution for workers.

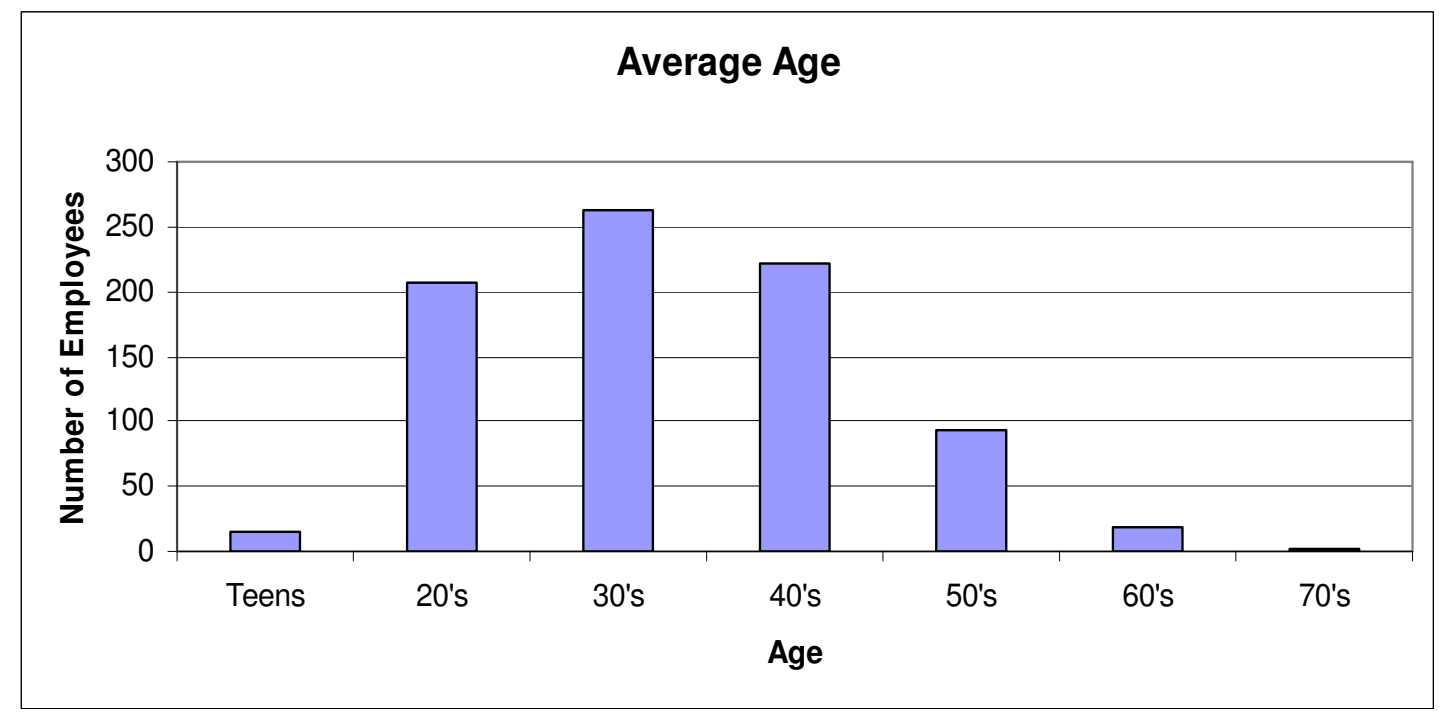

Figure 3.3: Average Age of Workers

The median age of the American worker is expected to reach 40.7 years in 2008 (McClellan and Holden, 2001; Bureau of Labor Statistics, 2008f). The ages ranged from 18 to 70, with the mode being 30. The average age of Salvadorans responding to the question was 37 years. The average age of Mexican respondents was 30 years. For those workers born in the U.S., the average age was 36 years, and Honduran workers reported an average age of 35 years. Age distribution by country of birth is shown in Figure 3.4. Numbers of workers are represented as a percentage of workers from that country (Golden and Skibniewski, 2008c). 


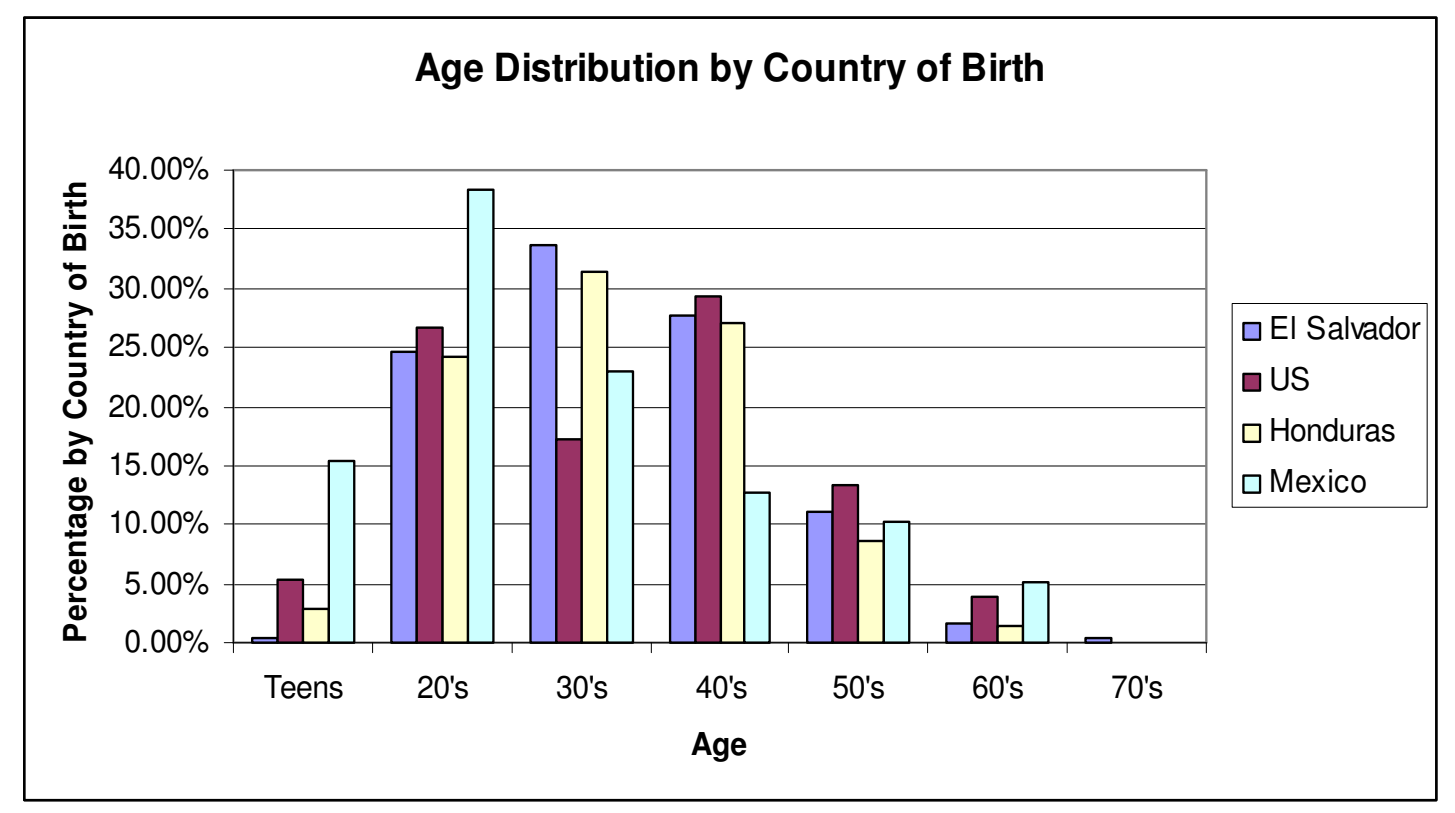

Figure 3.4: Age Distribution by Country of Birth

\subsubsection{Education}

Only $26 \%$ of respondents reported that they graduated from high school; $36 \%$ have a $6^{\text {th }}$ grade education or less. To put this number in perspective, $69 \%$ of adult immigrants nationally have graduated high school, and $91 \%$ of native-born individuals have graduated high school (Camarota, 2005). Figure 3.5 depicts the education distribution by country of birth. Again, numbers of workers are represented as a percentage of workers from that country. While zero respondents who were born in the U.S. reported receiving less than an $8^{\text {th }}$ grade education, $34 \%$ of respondents born in Mexico, more than $40 \%$ of respondents born in El Salvador, and more than $65 \%$ of respondents born in Honduras reported receiving a $6^{\text {th }}$ grade education or less. These numbers far exceed national average estimates for adult immigrants, and certainly contribute to the dismal literacy rate experienced in the field (Golden and Skibniewski, 2008c). 


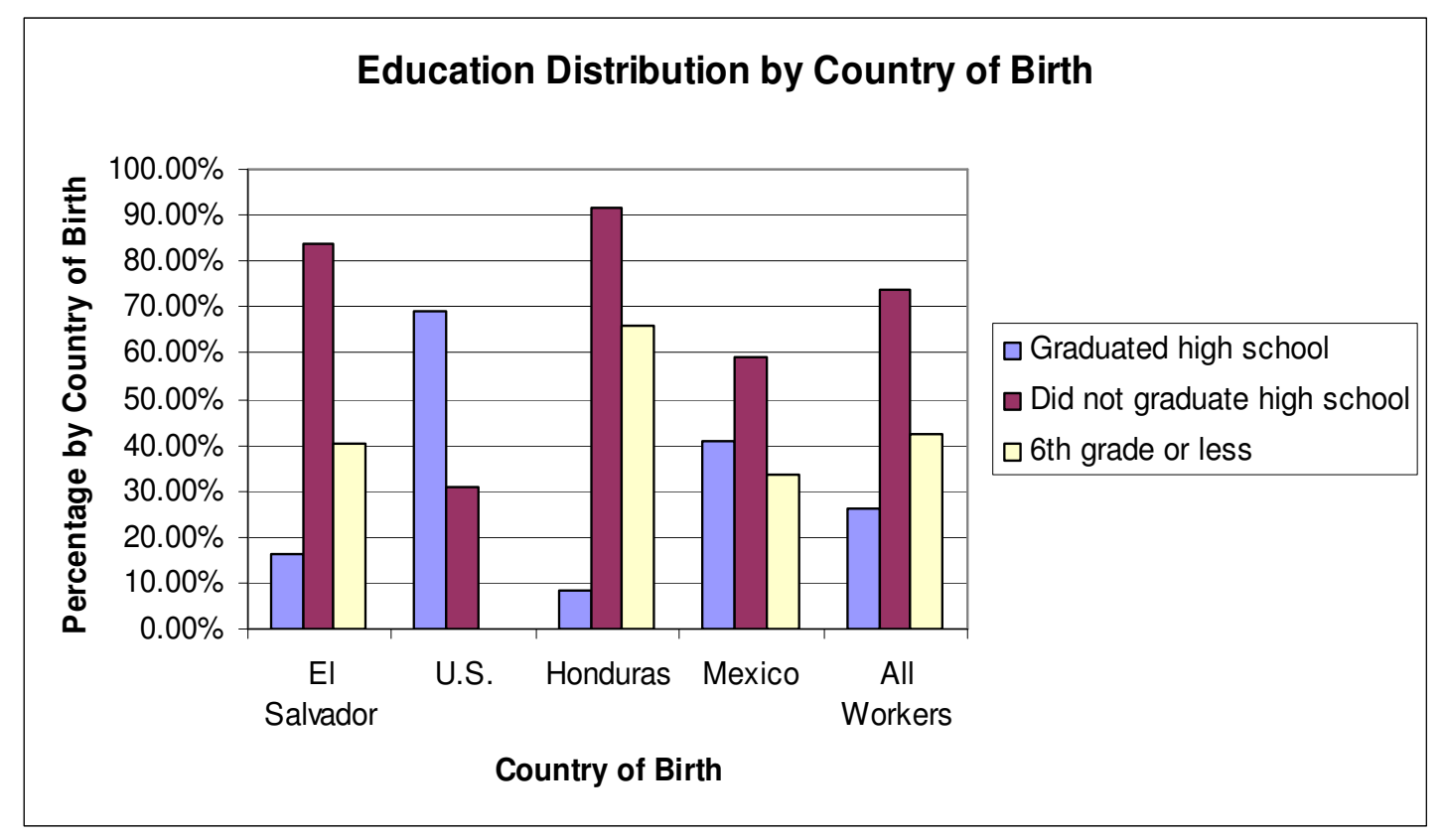

Figure 3.5: Education Distribution by Country of Birth

\subsubsection{Wages and Benefits}

Employee wages ranged between $\$ 10$ and $\$ 30$ per hour, with the average hourly earning of $\$ 17.54$ (see Figure 3.6). The average hourly wage for the undocumented workers was \$16.61. For "quasi-legal" workers, the average hourly wage was $\$ 17.66$. The average hourly wage for undocumented and "quasi-legal" workers was $\$ 17.25$. These are the workers affected most by immigration reform legislation and those that would be eligible for the prevailing wage provision in the Senate bill (Senate, 2006). For the legally authorized workers the average hourly wage was \$17.92: $\$ 18.25$ for citizens, and $\$ 17.74$ for legal permanent residents. Citizens earned on average $9 \%$ more than illegal immigrants. Citizens and legal immigrants earned on average $3.74 \%$ more than illegal or "quasi-legal" immigrants, and citizens 
earned on average $2.79 \%$ more than legal permanent residents (Golden and Skibniewski, 2008c).

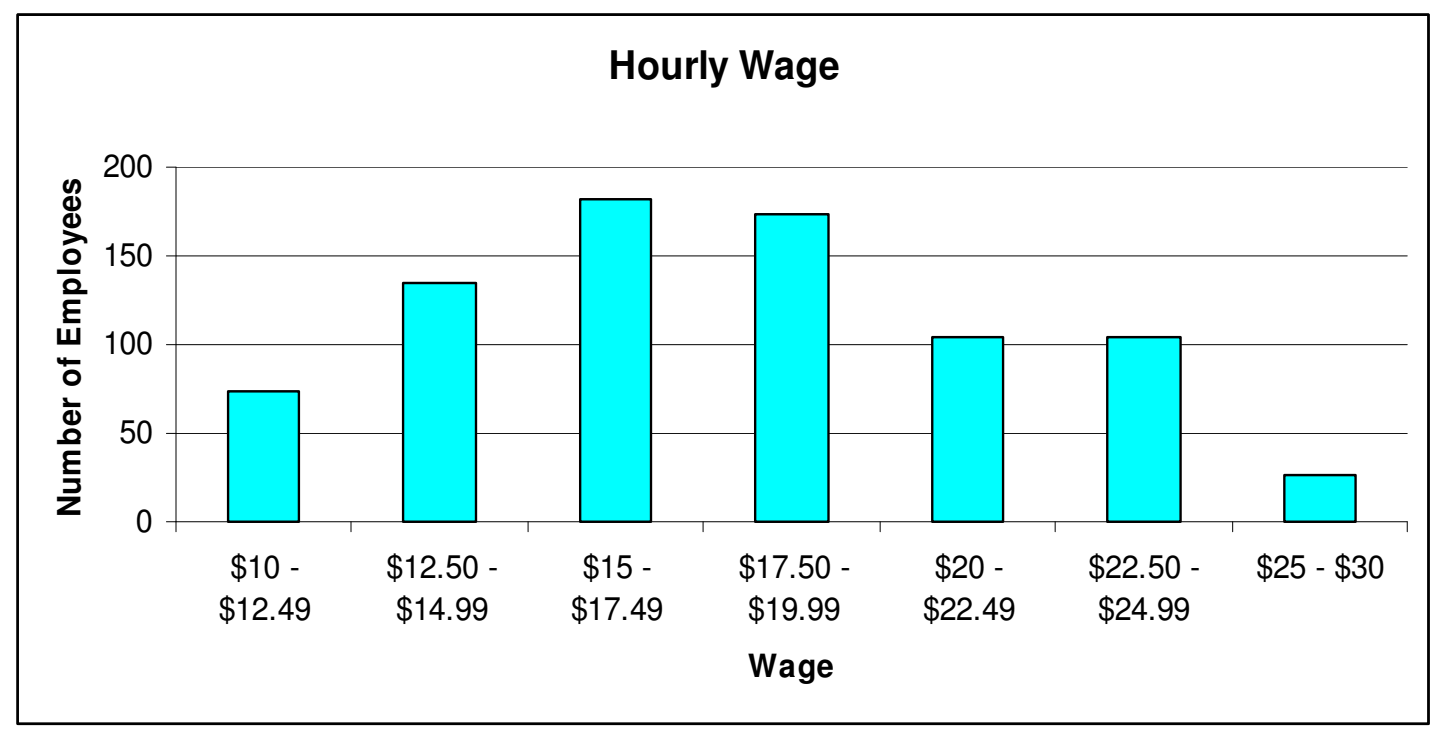

Figure 3.6: Average Wages for Workers

Most employees interviewed reported to work at least 40 hours per week. However, there were 88 employees that stated part-time or seasonal employment, which was $10.96 \%$ of respondents answering the question. However, $30.03 \%$ of respondents reported working less than 12 months in the previous year: $5.28 \%$ of citizens, $9.05 \%$ of LPRs, $6.78 \%$ of "quasi-legal" workers, and $9.3 \%$ of undocumented workers. Therefore, annual income was reported to be on average between $\$ 27,409$ and $\$ 33,241$. Figure 3.7 illustrates the annual income distribution for all of the workers interviewed (Golden and Skibniewski, 2008c). 


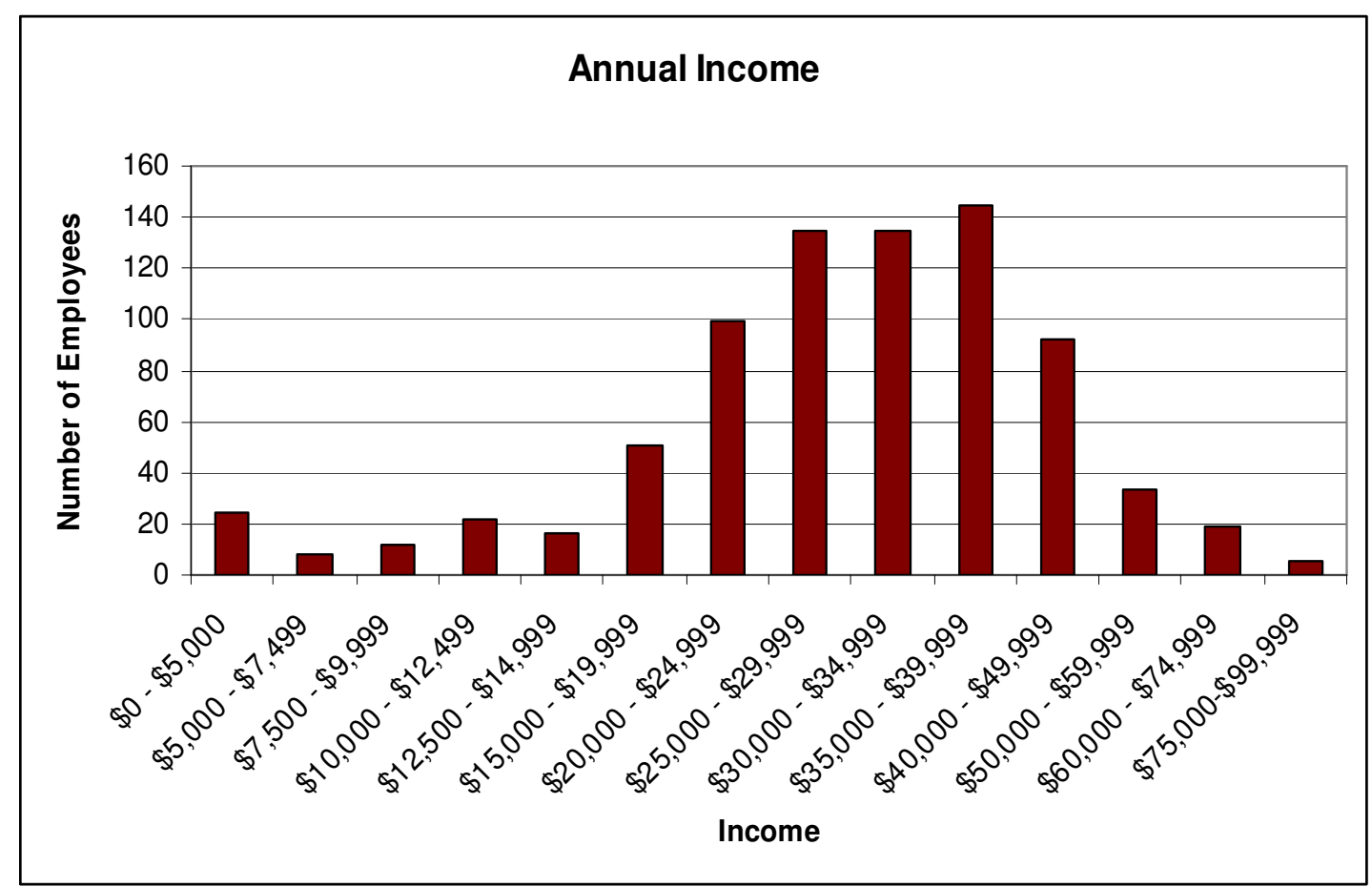

Figure 3.7: Annual Income Distribution for Workers

The annual income for citizens was between $\$ 31,091$ and $\$ 39,067$, for LPRs was between $\$ 29,431$ and $\$ 35,468$, for “quasi-legal" workers was between $\$ 28,509$ and $\$ 34,055$, for undocumented workers was between $\$ 25,185$ and $\$ 30,652$. The average annual income for legal workers was between $\$ 30,029$ and $\$ 36,763$, while the average annual income for illegal and "quasi-legal" workers was between $\$ 27,197$ and $\$ 32,712$. Figure 3.8 depicts the annual income of workers by immigration status. Immigration status had the most impact on worker earnings, over education or country of birth. For those workers who immigrated to the U.S. in or after the year 2000 , the average annual income was $\$ 25,167$, earning an average hourly wage of \$15.95 (Golden and Skibniewski, 2008c). 


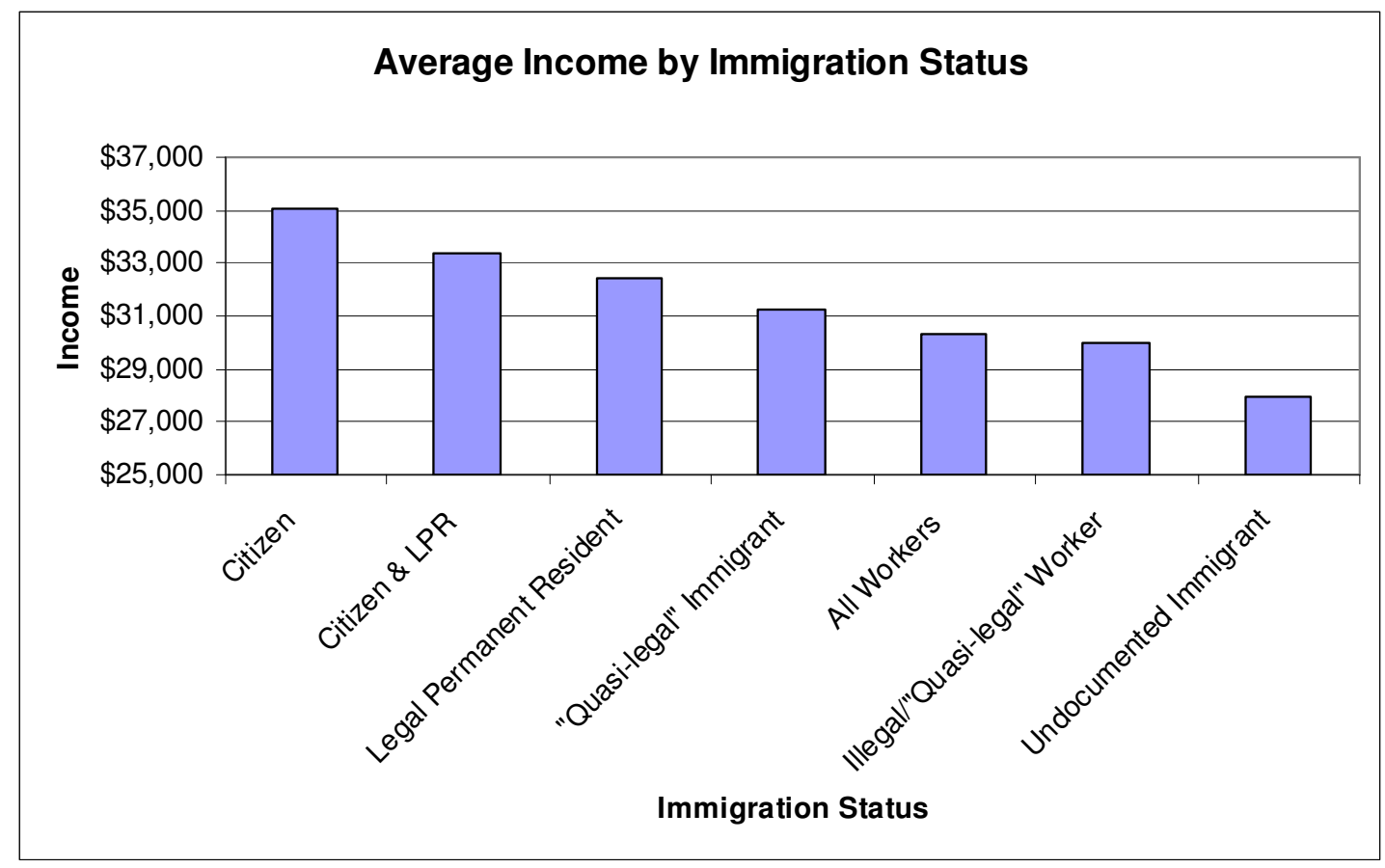

Figure 3.8: Annual Income Distribution by Immigration Status

Some research cites education is the best predictor of economic success for individual, regardless of immigration status (Camarota, 2004). This was not proven among the immigrant-saturated, low-skilled occupations in construction.

High school graduates earned on average \$29,038 annual income and \$16.47/hour. Workers with less than a high school education earned $\$ 30,777$ annually and $\$ 16.38 /$ hour. It is possible for the average hourly wage comparison to be more while the annual income comparison is less because some workers reported working fewer than 12 months. The average annual income for workers with a $6^{\text {th }}$ grade education or less was $\$ 30,591$ earning an average hourly wage of $\$ 17.07$. For workers with some college, the annual income was $\$ 30,416$ earning an average hourly wage of $\$ 15.70$ (Golden and Skibniewski, 2008c). Figure 3.9 depicts the average income of workers by educational attainment. 


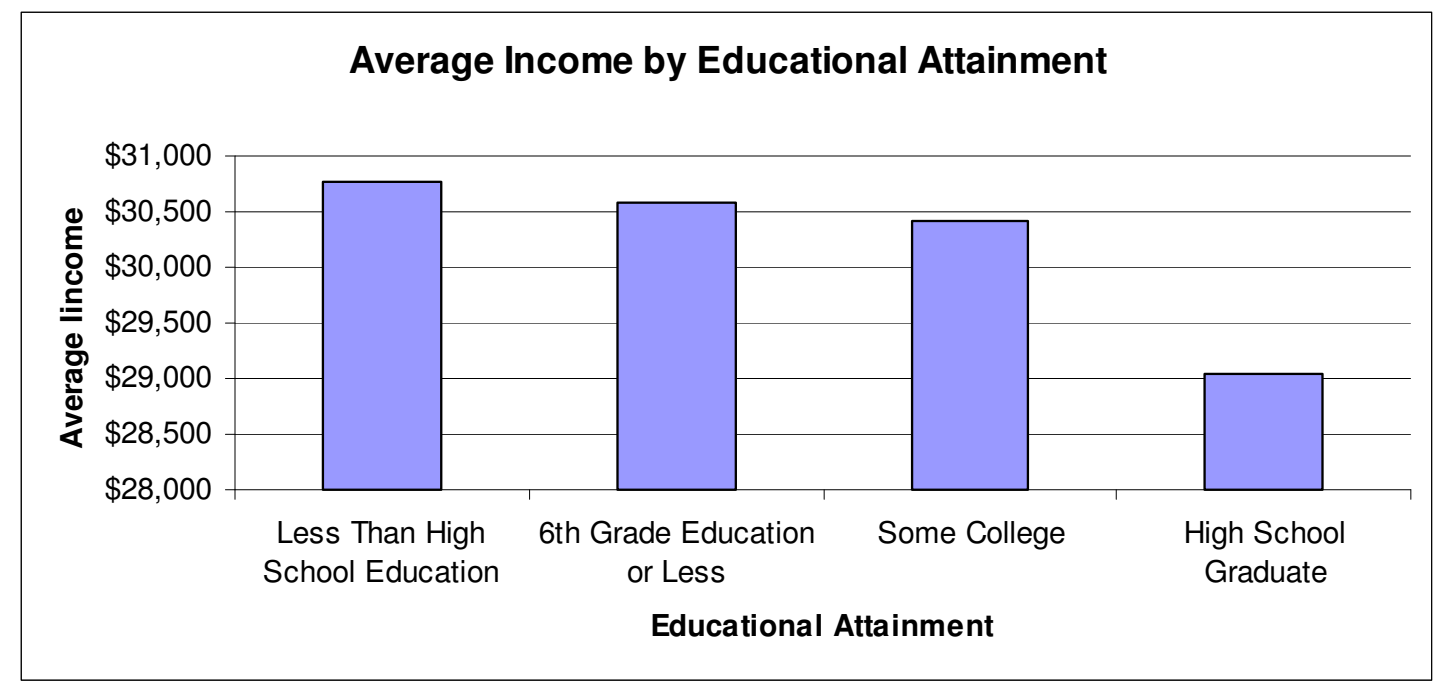

Figure 3.9: Average Income by Educational Attainment

Country of birth had little to do with earning potential as well. Figure 3.10 shows the wage distribution by country of birth. The average annual income was $\$ 27,985$ for workers born in the U.S., \$32,788 for workers born in El Salvador, \$27,720 for workers born in Honduras, and \$24,791 for workers born in Mexico. Workers born in the U.S. reported earning less than immigrant workers. The difference between the average earnings of Salvadoran workers on the high end and Mexican workers on the low end is likely a result of time in service. Mexican respondents were younger and had been in the U.S. fewer years on average than Salvadoran respondents (Golden and Skibniewski, 2008c). 


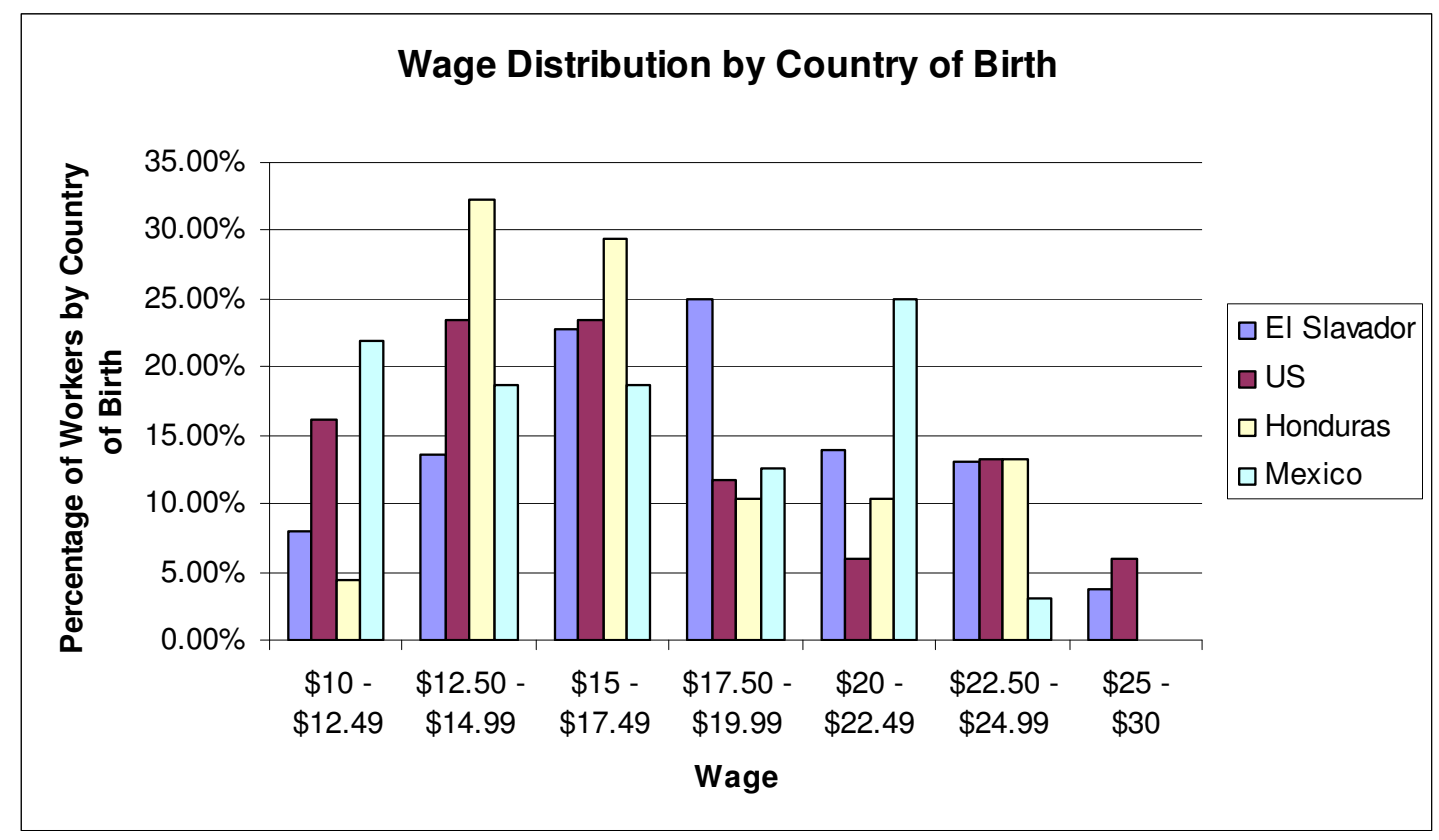

Figure 3.10: Wage Distribution by Country of Birth

Immigration status appears to have had the most impact on the earnings of workers, over education or country of birth. Length of service obviously weighs heavily in wage determination. This research found that $22 \%$ of respondents had immigrated to the U.S. in or after the year 2000; $19 \%$ of Salvadorans and 37\% of Mexicans. Almost $50 \%$ of undocumented immigrants reported having immigrated in or after the year 2000. So, one could argue that length of service had the most impact on earning potential, however, as shown here, immigration status has substantial bearing on length of service as well (Golden and Skibniewski, 2008c).

Only 55\% of respondents reported health insurance coverage; $37 \%$ of the undocumented population reported health insurance coverage. The average hourly wage reported for those who also choose to participate in a health insurance program was $\$ 18.03 /$ hour. The average hourly wage for those who do not participate in a health insurance program was $\$ 15.73 /$ hour. Vacation benefits were reported by $27 \%$ 
of employees; only $11 \%$ of the undocumented population reported receiving vacation benefits. This implies and confirms a large turnover of employees since vacation benefits are typically offered to those who employees who have been with a company a number of years. This qualification ranged from 1-3 years for companies contacted (Golden and Skibniewski, 2008c).

\section{$\underline{3.4 \text { Chapter Summary }}$}

The results of this research reveal approximately 55\% undocumented and "quasilegal" immigrant workers in construction in the Washington, D.C. metropolitan area, with an estimated $22 \%$ being truly undocumented. Again, because random sampling of the immigrant population of construction workers across the geographic region is not possible, a representative sample could not be drawn from this data. Extrapolation of the quantitative survey results to the universe of construction workers in the Washington, D.C. metropolitan area requires judgment. Thus, the conclusions drawn from the survey data are provisional; however, they are strongly supported by this and other research.

The sample for this research comes from a large concrete subcontractor in the Washington, D.C. metropolitan area, a subsidiary of a large general contractor operating nationally. Therefore, the strongest correlations between this data and data for the geographic region will be with companies working in commercial construction on similar-sized projects with similar hiring practices. Where these similarities exist, inferences about the characteristics of the immigrant workforce in construction may be drawn. 
While there were several similarities noted between these results and the results from national data, there were also notable differences. Nationally, $31 \%$ of immigrants reported less than a high school education; this survey revealed $74 \%$ of respondents without a high school education and $36 \%$ with less than a $6^{\text {th }}$ grade education (Camarota, 2005). Also, this research found that immigration status contributed the most to the earning potential of the workers, while nationally focused research cited educational attainment as the leading predictor of economic success (Camarota, 2004). The most compelling finding, however, was that illegal immigrants make up a far greater proportion of the construction workers in low-skilled trades than indicated by national averages, 55\% as compared to between 20 and 36\% nationally (Passel, 2006). This will increase the impact of immigration and immigration reform substantially for the Washington, D.C. metropolitan region. 


\section{Chapter 4: Impact of Immigration and Immigration Reform Legislation}

This research evaluates the impact of immigration and immigration reform legislation based on four factors: 1) prevailing wage provision in legislation, 2) forced tax compliance of the workforce, 3) market correction from currently depressed wages resulting from immigrant-penetration into the workforce, and 4) a labor shortage resulting from a depleted supply of immigrant labor.

\subsection{Prevailing Wage Provision}

The impact on construction project costs from a prevailing wage provision in legislation depends on the number of workers affected by the legislation and on the difference between the prevailing wage determination and the median wage for workers in a specific trade. Most often, prevailing wage terminology is used to refer to the so called Davis-Bacon wages under the Davis-Bacon Act of 1931, and this was the case proposed in the first bill that passed the U.S. Senate (2006). The expected increase in wages due to the proposed prevailing wage provision in the legislation $\left(\mathrm{I}_{\mathrm{pw}}\right)$ is given by equation (1).

$$
I_{p w}=0.55 x \times L C \times\left(\frac{P W}{M W}-1\right)
$$

where 0.55 is the estimate of illegal immigrant workers in the Washington, D.C. metropolitan region, $\mathrm{x}$ represents percentage of those illegal immigrant workers eligible for the prevailing wage provision determined by the legislation, MW is the 
median wage and PW is the prevailing wage and LC is the labor costs (Golden and Skibniewski, 2008a).

\subsection{Tax Compliance}

There are 2 studies in particular that have examined tax compliance by illegal immigrants (North and Houstoun, 1976; Rea and Parker, 1993). In The High Cost of Cheap Labor: Illegal Immigration and the Federal Budget, a tax compliance rate of $55 \%$ is used in order to examine the fiscal impact of illegal immigration on the federal budget. This assumption is based on the North and Houstoun and the Rea and Parker reports. In the report, Immigrants in New York: Their Legal Status, Incomes, and Taxes, an estimate of $60 \%$ tax compliance is purported based on the same two research studies (Passel and Clark, 1998).

On detailed review of these referenced reports, the rate of tax compliance among illegal immigrants used in these studies may be low. The earlier report referenced dealing with tax compliance, The Characteristics and Role of Illegal Aliens in the U.S. Labor Market: An Exploratory Study published in 1976, was the result of a survey administered to 793 apprehended illegal immigrants who had worked for wages in the United States for at least two weeks. The interviews were conducted in 19 geographic locations across the U.S.: Los Angeles, New York City, San Antonio, Chicago, Miami, San Francisco, Detroit, Seattle, and Washington, D.C. The statistical relevance of the data from the 1976 study The Characteristics and Role of Illegal Aliens in the U.S. Labor Market: An Exploratory Study is not purported. The authors admit the sampling strategy does not reveal statistically sound data. However, insomuch as the sample is representative of the illegal workers in the 
country at that time, the data has been used extensively to make assumptions about the illegal workforce.

This study found that $77.3 \%$ of illegal immigrants interviewed had Social Security taxes withheld. For those working in non-farm jobs, the compliance rate for Social Security taxes was even higher, $80.5 \%$. During the time of the research, there were instances that employers were obligated to pay Social Security taxes, but could forego withholding income taxes, particularly in the case of low income-earning employees. The report indicated that $73.2 \%$ of illegal immigrants interviewed had federal income taxes withheld (North and Houstoun, 1976). Currently, employers must withhold income taxes on all non-resident alien employees, and non-resident alien employees are only allowed to claim one exemption for withholding purposes.

The more recent study of tax compliance among illegal immigrants was conducted in San Diego County. The study, Illegal Immigration in San Diego County: An Analysis of Costs and Revenues, was commissioned by the California State Legislature as part of a broader study on the fiscal impact of illegal immigrants on public agencies in the state. The report is based on a survey conducted of 308 self-identified illegal immigrants from a variety of locations throughout the county: medical clinics, social service agencies, soup kitchens, detention facilities, street corners, migrant encampments, and local day-labor gather points. This report purported approximately 54\% tax compliance among illegal immigrants (Rea and Parker, 1993).

The 1976 study, The Characteristics and Role of Illegal Aliens in the U.S. Labor Market: An Exploratory Study, reported only $27.9 \%$ tax compliance in regions bordering Mexico (North and Houstoun, 1976). This compares to the 54\% reported 
in 1993 in the study, Illegal Immigration in San Diego County: An Analysis of Costs and Revenues (Rea and Parker, 1993). The noted increase is likely due to the change in legislation during that time period assessing penalties to employers who knowingly hire illegal immigrants and to changes in the tax legislation requiring withholding on all non-immigrant employees. The rate of deductions withheld on the East Coast was almost twice that of the Southwest.

While there is no way to be certain of the tax compliance rate among illegal workers, given the previous studies and the geographic location of this research, a tax compliance rate of $80 \%$ is assumed for this study. This seems a reasonable assumption based on prior research and on discussions with local employers during the administration of the survey. Most employers insist that they comply with immigration law and tax law. However, there were several who admitted knowingly hiring illegal immigrants and evading the tax laws.

For the reasons stated above, it is estimated that $20 \%$ of illegal immigrant workers are paid "off the books." If illegal immigrants makeup 55\% of construction workers, then $11 \%$ of the population of construction workers is estimated to be paid "off the books."

Labor burden was estimated to be $10.2 \%: 3.7 \%$ for workers' compensation insurance, $6.5 \%$ for unemployment insurance costs and for federal, state, and Social Security taxes. These are national averages for the construction industry based on BLS data (Bureau of Labor Statistics, 2007).

Therefore, the increase stemming from having to pay labor burden on all employees $\left(\mathrm{I}_{\mathrm{tx}}\right)$ is indicated in equation (2) (Golden and Skibniewski, 2008a). 
$I_{t x}=0.11 \times L C \times 0.102=0.01122 \times L C$,

where 0.11 represents the $11 \%$ of construction workers paid "off-the-books," LC is the labor costs for the project, and 0.102 is the labor burden estimate.

\subsection{Wage Depression}

There are two studies in particular that approach the impact of immigration on nativeborn worker wages without spatial restrictions. Spatial restrictions tend to mask the impact of immigration on local economies because immigrants are attracted to geographic areas with economic growth. Both immigrant and native-born migration patterns are affected by economic conditions, thus creating a national economic equilibrium (Camarota, 1997).

In the most recent study, The Labor Demand Curve is Downward Sloping: Reexamining the Impact of Immigration on the Labor Market, the national impact of immigration on the wages of native-born workers shows a reduction in the weekly earnings of native-born workers of $4.9 \%$ on average. This study finds a more substantial reduction, 8.9\%, for high school dropouts between 1980 and 2000 assuming an influx of immigrants of $11 \%$. From our survey results, this impact more closely resembles the construction workers, particularly those detailed occupations with high immigrant-labor penetration, as 75\% reported not finishing high school and $43 \%$ reported an education level of $6^{\text {th }}$ grade or less. 
The study uses a linear regression model with the log weekly earnings of native-born workers as the dependent variable and the percent immigration within a skill group as an independent variable. Skill groups are defined as a combination of education and working experience. The findings show that for high school dropouts, the reduction in wages range from a high of $12.7 \%$ to a low of $1.8 \%$, with an average of $7.4 \%$ reduction across all skill levels depending on work experience. The average reduction for high school dropouts with less than 20 years of work experience was 10.4\%. The highest reductions are estimated for those with 11-20 years of experience. This data is important because it is this population that most closely resembles the population of immigrant construction workers in the Washington, D.C. region. Decennial census data from 1960-2000 were used in this study (Borjas, 2003, 2004).

A previous study, The Effect of Immigrants on Low-Skilled Native Workers: Evidence from the 1991 Current Population Survey, found remarkably similar results using only education as an additional modifier for a particular group. This study also used a linear regression model in order to define the relationship between earned wages and percent immigrant penetration within an occupation. For low-skilled occupations, those requiring only a high school diploma or less, the study found a $0.7 \%$ reduction in weekly earnings of native-born workers for every $1 \%$ increase in immigrant labor within the occupation. The dependent variable in this model was the log of the weekly earnings, and an independent variable was the percentage of immigrants within the occupation. With an estimate of immigrants in these low-skilled occupations between 15 and 19 percent, the estimate of wage reduction expected for 
native-born workers in these same occupations is between 10.5 and 13 percent. The data for this study were taken from the 1991 CPS (Camarota, 1997).

For this research, a wage depression of $11 \%$ due to immigrant penetration into the low-skilled, immigrant-saturated construction occupations of concrete, masonry, drywall, painting, flooring, and roofing is assumed. Immigrant-saturated trades are defined as those in the construction industry where $20 \%$ or more of the workers are estimated to be illegal according to the study, The Size and Characteristics of the Unauthorized Migrant Population in the U.S.: Estimates Based on March 2005 Current Population Survey (Passel, 2006). This estimate is the average from the two studies, using only those with 20 years or less of experience from the Borjas study, as those most closely resemble the population of construction workers taken from the survey conducted as part of this research. This is a reasonable assumption based on the low-skilled nature of the work and the poorly educated population under consideration.

Should immigration become more restrictive, the supply of immigrant labor dissipate, and native-born workers be substituted for their immigrant counterparts, given the findings of this research, a corresponding market correction could be anticipated. Using an average effect of $11 \%$ depression of wages for low-skilled workers, like those working in the immigrant-saturated construction trades, the increase in labor costs from this market correction of currently depressed worker wages $\left(\mathrm{I}_{\mathrm{d}}\right)$ is defined by equation (3).

$I_{d}=0.11 \times T L C$, 
where TLC is the total labor costs for the project (Golden and Skibniewski, 2008a).

\subsection{Labor Shortage}

An additional impact suspected from immigration reform would be a labor shortage in the immigrant-saturated trades in construction. Stricter enforcement of current laws would increase the risk of employing illegal immigrants, as would enactment of harsher penalties in new legislation. Broader implementation of the Electronic Employment Eligibility Verification System would also make document fraud more difficult to successfully perpetrate. Therefore, it is likely that the industry would experience a labor shortage in the immigrant-saturated trades.

Basically, a labor shortage can be defined as a situation where the demand for labor in a particular market exceeds the supply. There are several indicators of supply and demand forces in the economy. Unemployment rate, number of workers unemployed, and job openings reported within an industry may be used to gauge supply forces within a labor market, while gross domestic product, number of workers employed in the labor market within an industry, and spending within and industry may be used to assess the demand forces. Examination of these forces over time allows for an evaluation of the supply and demand and the associated impact on worker wages within the labor market studied (Veneri, 1999).

Regression analysis was chosen as the technique to predict the impact of a labor shortage on construction worker wages, as prediction of a dependent variable based on response of an independent variable is a primary purpose of this type of evaluation. Data for this analysis are national estimates taken from the Bureau of 
Labor Statistics (2008a, 2008b, 2008c, 2008d). Construction worker wages was assigned as the dependent variable, $\mathrm{y}_{\mathrm{t}}$. The time interval for this model was monthly. The regression analysis used the least-squares method of fitting the data to model. The multiple linear regression model with three independent variables is expressed as

$y_{t}=\beta_{0}+\beta_{1} x_{1 t}+\beta_{2} x_{2 t}+\beta_{3} x_{3 t}+\varepsilon_{t}$,

where

$\mathrm{y}_{\mathrm{t}}=$ dependent variable,

$\beta_{0}=\mathrm{y}$-intercept,

$\beta_{1}=$ slope of $\mathrm{y}$ with variable $\mathrm{x}_{1}$ holding variables $\mathrm{x}_{2}$ and $\mathrm{x}_{3}$ constant,

$\beta_{2}=$ slope of $\mathrm{y}$ with variable $\mathrm{x}_{2}$ holding variables $\mathrm{x}_{1}$ and $\mathrm{x}_{3}$ constant,

$\beta_{3}=$ slope of $\mathrm{y}$ with variable $\mathrm{x}_{3}$ holding variables $\mathrm{x}_{1}$ and $\mathrm{x}_{2}$ constant, and

$\varepsilon_{\mathrm{t}}=$ random error in $\mathrm{y}$ for observation $\mathrm{t}$.

A forward selection process was used to select the independent variables for the regression model. Job openings reported in the construction industry was selected first as a predictor of labor shortage, which will be the variable used to assess the likely impact on construction worker wages should the illegal immigrant population dissipate. Job openings data were obtained from the Bureau of Labor Statistics Job Openings and Labor Turnover Survey (JOLTS) (2008c). JOLTS data have been collected only since December 2000. The survey began as a response to the need from industry for data on job openings, hires, and separations. The data are used in 
national economic policy development, economic research analysis, and industry studies on retention, education, and training necessities. JOLTS data serve as indicators of labor shortages at the national level and are collected per industry. Prior to JOLTS, there was no survey instrument available to assess labor shortages and other economic indicators were inadequate in assessing the unmet demand for labor. Data for JOLTS are collected from a sample of 16,000 non-agricultural industries in the 50 states and Washington, D.C. (www.bls.gov).

The number of construction workers employed was selected as a second criterion to assess the demand in the market. This variable was selected in order to evaluate the impact of demand on worker wages in the construction market. The number of construction workers in production was obtained from Current Employment Statistics (CES) program, (Bureau of Labor Statistics, 2008d). Each month the CES program surveys approximately 150,000 businesses and government agencies, which represent around 390,000 individual worksites. These data are used to provide industry information on employment, hours, and earnings of workers on non-farm payrolls (www.bls.gov).

The regression analysis was first conducted with only these supply and demand variables as the predictor variables with the following results (Table 4.1). 


\section{Table 4.1: Multiple Linear Regression Estimate of Construction Worker Wages Based on Job Openings and Construction Workers Employed}

\begin{tabular}{lrlrl} 
Variable & $\begin{array}{l}\text { Regression } \\
\text { Coefficient }\end{array}$ & $\begin{array}{l}\text { Standard } \\
\text { Error }\end{array}$ & \multicolumn{1}{c}{ t-Stat } & P-value \\
\hline $\begin{array}{l}\text { Intercept } \\
\text { Job }\end{array}$ & 4.2928554 & 1.23932057 & 3.46387811 & 0.000849174 \\
$\begin{array}{l}\text { Openings } \\
\text { Construction }\end{array}$ & -0.007576 & 0.00247363 & -3.06281555 & 0.002965693 \\
Workers & 0.0029091 & 0.0002584 & 11.2580746 & $2.57597 \mathrm{E}-18$ \\
\hline
\end{tabular}

Regression equation characteristics

Multiple $\mathrm{R}=0.810012709 \quad \mathrm{DW}=0.175277234$

Adjusted R Square $=0.647733287$

$\mathrm{N}=85$

The results of this analysis are respectable considering the multitude of additional economic factors that affect worker wages. From the t-Stat and the P-values, it is determined that a significant relationship between the variables exist. The coefficient of multiple determination is 0.81 , indicating that approximately $81 \%$ of the response in the dependent variable, construction worker wages, is determined by the variation of the independent variables, job openings in construction and number of construction workers employed. When adjusted for the number of explanatory variables in the model and the sample size, the adjusted coefficient of determination becomes 0.66 , which is less reliable, but still notable considering the limitations of the data.

The final variable, the average hourly earnings of all production workers for the same time period, was used to account for other forces on construction worker wages such as inflation, economic growth, etc (Bureau of Labor Statistics, 2008b). Identification 
of these economic factors individually was not necessary, as this research is focused on the impact of a labor shortage identified by the job openings data and not on identifying all of the factors affecting worker wages. Common data for all of the predictor variables were available for the time period from December 2000 to December 2007 (see Table B.1, Appendix B).

The results for the fitted model are shown in Table 4.2.

Table 4.2: Multiple Linear Regression Estimate of Construction Worker Wages Based on Job Openings, Construction Workers Employed, and Average Wage of All Workers

\begin{tabular}{lrlll} 
Variable & $\begin{array}{l}\text { Regression } \\
\text { Coefficient }\end{array}$ & $\begin{array}{l}\text { Standard } \\
\text { Error }\end{array}$ & t-Stat & P-value \\
\hline Intercept & 5.117253 & 0.17731615 & 28.8594865 & $2.20713 \mathrm{E}-44$ \\
Job Openings & 0.0007445 & 0.00037698 & 1.97497358 & 0.051677876 \\
$\begin{array}{l}\text { Construction } \\
\text { Workers }\end{array}$ & -0.000653 & $6.7633 \mathrm{E}-05$ & -9.65425257 & $4.05939 \mathrm{E}-15$ \\
Avg Wage & & & & \\
All Workers & 1.1146042 & 0.01774178 & 62.8236942 & $1.73373 \mathrm{E}-70$ \\
\hline
\end{tabular}

Regression equation characteristics

Multiple $\mathrm{R}=0.996536268 \quad \mathrm{DW}=0.68000068$

Adjusted R Square $=0.992828405$

$\mathrm{N}=85$

The addition of the final predictor variable improves significantly the results of the analysis. From the t-Stat and the P-values, a significant relationship between the variables is found. The coefficient of multiple determination is 0.99 , indicating that approximately $99 \%$ of the response in the dependent variable, construction worker wages, is determined by the variation of the independent variables, job openings in construction and number of construction workers employed. When adjusted for the 
number of explanatory variables in the model and the sample size, the adjusted coefficient of determination is still 0.99 .

From equation (4), the model, therefore, becomes,

$y_{t}=5.117+0.00074 x_{1 t}-0.00065 x_{2 t}+1.115 x_{3 t}$.

The model shows significant autocorrelation among the residuals as evident by the Durbin-Watson Statistic, DW $=0.68$. In order to correct for the correlated errors, the Cochrane-Orcutt method was applied (Cochrane and Orcutt, 1949; Chatterjee and Hadi, 2006). The autocorrelation parameter, $\rho$, was estimated by equation (6).

$$
\hat{\rho}=\frac{\sum_{t-2}^{n} e_{t} e_{t-1}}{\sum_{t}^{n} e_{t}^{2}}
$$

For the model above, the autocorrelation parameter was estimated to be 0.6542 .

The regression model in equation (4) may be expressed as,

$$
\begin{aligned}
& \varepsilon_{t}=y_{t}-\beta_{0}-\beta_{1} x_{1 t}-\beta_{2} x_{2 t}-\beta_{3} x_{3 t} \\
& \varepsilon_{t-1}=y_{t-1}-\beta_{0}-\beta_{1} x_{1 t-1}-\beta_{2} x_{2 t-1}-\beta_{3} x_{3 t-1} .
\end{aligned}
$$

Assuming successive errors are correlated,

$$
\varepsilon_{t}=\rho \varepsilon_{t-1}+\omega_{t} \quad|\rho|<1,
$$


where $\omega_{\mathrm{t}}$ is the normally independently distributed error with zero mean and constant variance.

Combining these equations, our model becomes,

$y_{t}-\beta_{0}-\beta_{1} x_{1 t}-\beta_{2} x_{2 t}-\beta_{3} x_{3 t}=\rho\left(y_{t-1}-\beta_{0}-\beta_{1} x_{1 t-1}-\beta_{2} x_{2 t-1}-\beta_{3} x_{3 t-1}\right)+\omega_{t}$.

Rearranging terms in the equation (10) yields,

$y_{t}-\rho y_{t-1}=\beta_{0}(1-\rho)+\beta_{1}\left(x_{1 t}-\rho x_{1 t-1}\right)+\beta_{2}\left(x_{2 t}-\rho x_{2 t-1}\right)+\beta_{3}\left(x_{3 t}-\rho x_{3 t-1}\right)+\omega_{t}$.

Substitution yields,

$y_{t}^{*}=\beta_{0}^{*}+\beta_{1}^{*} x_{1 t}^{*}+\beta_{2}^{*} x_{2 t}^{*}+\beta_{3}^{*} x_{3 t}^{*}+\omega_{t}$

where

$$
\begin{aligned}
& y_{t}^{*}=y_{t}-\rho y_{t-1}, \\
& x_{1 t}^{*}=x_{1 t}-\rho x_{1 t-1}, \\
& x_{2 t}^{*}=x_{2 t}-\rho x_{2 t-1}, \\
& x_{3 t}^{*}=x_{3 t}-\rho x_{3 t-1}, \\
& \beta_{0}^{*}=\beta_{0}(1-\rho),
\end{aligned}
$$


$\beta_{1}^{*}=\beta_{1}$,

$\beta_{2}^{*}=\beta_{2}$,

$\beta_{3}^{*}=\beta_{3}$.

Since the $\omega$ 's are uncorrelated, equation (12) represents a linear model with uncorrelated errors. So, running the regression again with the transformed variables yields the results found in Table 4.3.

Table 4.3: Multiple Linear Regression Estimate Using Transformed Variables

\begin{tabular}{lcrrr} 
Variable & $\begin{array}{l}\text { Regression } \\
\text { Coefficient }\end{array}$ & $\begin{array}{l}\text { Standard } \\
\text { Error }\end{array}$ & \multicolumn{1}{l}{ t-Stat } & \multicolumn{1}{l}{ P-value } \\
\hline Intercept & 1.6208257 & 0.10775827 & 15.04131072 & $4.94305 \mathrm{E}-25$ \\
Job Openings & -0.000301 & 0.000276 & -1.090593451 & 0.27872577 \\
Construction & & & & \\
Workers & -0.000491 & $9.8322 \mathrm{E}-05$ & -4.989701317 & $3.45753 \mathrm{E}-06$ \\
Avg Wage & & & & \\
All Workers & 1.0937207 & 0.03160511 & 34.6058184 & $6.777 \mathrm{E}-50$ \\
\cline { 2 - 5 }
\end{tabular}

Regression equation characteristics

Multiple $\mathrm{R}=0.986770203 \quad \mathrm{DW}=1.902393278$

Adjusted R Square $=0.972729763$

$\mathrm{N}=85$

The estimates of the parameters in the transformed model are

$\hat{\beta}_{0}=\frac{\hat{\beta}_{0}^{*}}{1-\hat{\rho}}$,

$\hat{\beta}_{1}=\hat{\beta}_{1}^{*}$, 


$$
\begin{aligned}
& \hat{\beta}_{2}=\hat{\beta}_{2}^{*}, \\
& \hat{\beta}_{3}=\hat{\beta}_{3}^{*} .
\end{aligned}
$$

Using the estimates for the parameters, the model becomes,

$$
y_{t}=4.6877-0.000301 x_{1 t}-0.000491 x_{2 t}+1.0937 x_{3 t} .
$$

The Durbin-Watson Statistic of 1.9024 indicates the success of the transformation in adjusting for the autocorrelation. The residual plots for the regression analysis are shown in Appendix $\mathrm{C}$ and demonstrate the adequacy of the model.

From this model, if the demand for construction workers in production remains at $5,850,000$ and the economy remains such that average worker wages remain at $\$ 17.50$ per hour, then a change in the number of job openings by 50,000 equates to a $0.1 \%$ change in the wages. In other words, if job openings increase by 50,000 , the construction worker wages increase by $0.1 \%$.

Illegal immigrants account for $14 \%$ of the construction worker population. The total construction worker population is approximately 7 million, so illegal immigrants make up about 1 million of the construction workers. If the illegal immigrants were eliminated from the workforce immediately, the industry might expect a $2 \%$ increase in wages in order to close the gap on the job openings created by the elimination of the illegal immigrant workers (Golden and Skibniewski, 2008b).

Therefore, the increase in worker wages due to a labor shortage may be expressed as $I_{s}$, equation (15). 


$$
I_{s}=\frac{\frac{J O}{50,000} \times 0.1}{100} \times T L C=2 \times 10^{-8} \mathrm{JO} \times T L C,
$$

where $\mathrm{JO}$ is the number of job openings reported in construction.

So, the total increase in labor costs $\left(\mathrm{I}_{\mathrm{T}}\right)$ from a prevailing wage provision in legislation, forced tax compliance as a result of mandatory employment verification,

an increase in wages from the currently depressed wages due to immigrant penetration in the labor market, and a resulting labor shortage from legislation or enforcement of current law becomes equation (16).

$I_{T}=I_{p w}+I_{p r}+I_{d}+I_{s}$

The percent increase in total project costs due to these impacts is then $\mathrm{I}_{\mathrm{T}}$ / total project costs.

\subsection{Chapter Summary}

In this chapter, there have been four factors identified that impact construction project costs related to immigration and immigration reform: 1) prevailing wage provision in legislation, 2) forced tax compliance of the workforce, 3) market correction from currently depressed wages resulting from immigrant-penetration into the workforce, and 4) a labor shortage resulting from a depleted supply of immigrant labor. Several equations were presented that quantify the impact of these factors. A model was presented, as well, that assesses the impact of a labor shortage on worker wages. 
The results of the model revealed that, holding the demand for construction workers in production and other economic factors constant, an increase of 50,000 in job openings reported in the construction industry results in an increase of $0.1 \%$ in construction worker wages. This is not a significant increase in worker wages.

In the next chapter, the methodology and assumptions identified and justified here will be used to quantify the impact on several construction projects in the Washington, D.C. metropolitan region. 


\section{Chapter 5: Quantifying the Impact}

To quantify the impact of this makeup of the construction workforces in the immigrant-saturated trades, a detailed analysis was conducted on cost data for five construction projects: three high-rise office buildings, one high-rise condominium, and one institutional construction project (see Table 3.1). The projects ranged in cost from $\$ 55$ million to $\$ 800$ million. The projects were all from Washington D.C. metropolitan region. The cost data analyzed in this chapter may be found in Appendix D, Table D.1.

\subsection{Impact of Prevailing Wage Provision}

It is estimated that $25 \%$ of the total population of illegal immigrants currently residing in the U.S. would be eligible for Deferred Mandatory Departure (DMD) as defined in the Senate Bill, S.2611, and thus eligible for the guest worker provision in the proposed legislation and the prevailing wages promised in the bill (Rector, 2006). If it is assumed that $55 \%$ of the construction workforces are illegal immigrants and $25 \%$ of that population is eligible to participate in this program, then $14 \%$ of the total population of construction workers would be eligible for the prevailing wage provision. These estimates are based on the parameters of the Comprehensive Immigration Reform Act of 2006 passed in the U.S. Senate (2006).

Application of equation (1), the impact to construction project costs from a prevailing wage provision in legislation would be up to an $8.92 \%$ increase in trade labor costs, a $2.34 \%$ increase in total labor costs, and slightly over a $1.5 \%$ increase in total project 
costs. The summary of this impact is shown in Table 5.1 (Golden and Skibniewski, 2008a).

Table 5.1: Impact on Project Costs Due to Prevailing Wage Provision Applied Only to Illegal Immigrant Labor

\begin{tabular}{lcccccc}
\hline \hline & Project & Project & Project & Project & Project & \\
& $\mathbf{1}$ & $\mathbf{2}$ & $\mathbf{3}$ & $\mathbf{4}$ & $\mathbf{5}$ & Average \\
\hline Concrete & $8.92 \%$ & $6.91 \%$ & $8.92 \%$ & $4.21 \%$ & $8.92 \%$ & $7.58 \%$ \\
Masonry & $1.21 \%$ & $1.07 \%$ & $1.21 \%$ & $-0.81 \%$ & $1.21 \%$ & $0.78 \%$ \\
Drywall & $7.78 \%$ & $7.19 \%$ & $7.78 \%$ & $6.34 \%$ & $7.78 \%$ & $7.37 \%$ \\
Terrazzo & $8.98 \%$ & $6.91 \%$ & $8.19 \%$ & $5.46 \%$ & $8.19 \%$ & $7.55 \%$ \\
Painting & $8.19 \%$ & $5.66 \%$ & $3.13 \%$ & $5.90 \%$ & $3.13 \%$ & $5.20 \%$ \\
Flooring & $3.13 \%$ & $0.88 \%$ & $6.19 \%$ & $1.63 \%$ & $6.19 \%$ & $3.61 \%$ \\
Roofing & & $6.19 \%$ & & & & \\
Project Labor & $1.24 \%$ & $1.78 \%$ & $3.51 \%$ & $1.66 \%$ & $3.48 \%$ & $2.34 \%$ \\
Project Total & $0.81 \%$ & $1.16 \%$ & $2.28 \%$ & $1.08 \%$ & $2.26 \%$ & $1.52 \%$ \\
\hline
\end{tabular}

This is assuming that employers are able to pay only those that are affected by the legislation the prevailing wage rate. This is not likely the case. Citizen and legal permanent resident workers are not likely to work for less than this prevailing wage rate along side temporary guest workers making the prevailing wage for the same work. So, assuming that the prevailing wage applies to $100 \%$ of the labor costs for the immigrant-saturated trades in these projects, trade labor costs increased up to $65 \%$, the total labor costs increase almost $17 \%$ and the total project costs increase 11.04\%. A summary of these findings is shown in Table 5.2 (Golden and Skibniewski, 2008a). 


\begin{tabular}{lcccccc}
\hline $\begin{array}{c}\text { Table 5.2: Increase in Project Costs Due to Prevailing Wage Provision } \\
\text { Applied to All Labor for }\end{array}$ & Immigrant-Saturated Trades \\
\hline \hline & Project & Project & Project & Project & Project \\
& $\mathbf{1}$ & $\mathbf{2}$ & $\mathbf{3}$ & $\mathbf{4}$ & $\mathbf{5}$ & Average \\
\hline Concrete & $64.89 \%$ & $50.27 \%$ & $64.89 \%$ & $30.64 \%$ & $64.89 \%$ & $55.12 \%$ \\
Masonry & $8.77 \%$ & $7.77 \%$ & $8.77 \%$ & $-5.89 \%$ & $8.77 \%$ & $5.64 \%$ \\
Drywall & $56.55 \%$ & $52.33 \%$ & $56.55 \%$ & $46.11 \%$ & $56.55 \%$ & $53.62 \%$ \\
Terrazzo & $65.31 \%$ & $50.27 \%$ & $59.56 \%$ & $39.69 \%$ & $59.56 \%$ & $54.88 \%$ \\
Painting & $59.56 \%$ & $41.15 \%$ & $22.78 \%$ & $42.93 \%$ & $22.78 \%$ & $37.84 \%$ \\
Flooring & $22.78 \%$ & $6.42 \%$ & $45.05 \%$ & $11.82 \%$ & $45.05 \%$ & $26.22 \%$ \\
Roofing & & $45.05 \%$ & & & & \\
Project Labor & $9.04 \%$ & $12.97 \%$ & $25.56 \%$ & $12.06 \%$ & $25.33 \%$ & $16.99 \%$ \\
Project Total & $5.87 \%$ & $8.43 \%$ & $16.61 \%$ & $7.84 \%$ & $16.46 \%$ & $11.04 \%$ \\
\hline
\end{tabular}

\subsection{Impact of Forced Tax Compliance}

A tax compliance rate of $80 \%$, as stated in chapter 4 , is assumed. So, it is estimated that $20 \%$ of illegal immigrant workers are paid "off the books." Assuming $55 \%$ of the employees working in the immigrant-saturated trades are illegal immigrants means $11 \%$ of the population of construction workers is likely to be paid "off the books."

Labor burden is estimated to be $10.2 \%: 3.7 \%$ for workers' compensation insurance, $6.5 \%$ for unemployment insurance costs and for federal, state, and Social Security taxes. These are national averages for the construction industry based on BLS data (Bureau of Labor Statistics, 2007).

Application of the labor burden to those estimated to be paid "off the books," equation (2) from chapter 4 , amounts to a $1.12 \%$ increase in trade labor costs. When applied to those immigrant-saturated trades, the average increase across the five 
projects was a $0.39 \%$ increase in total labor costs and a $0.26 \%$ increase in total project costs. Table 5.3 shows a summary of these impacts (Golden and Skibniewski, 2008a).

Table 5.3: Impact on Project Costs Due to Forced Tax Compliance for All Employees

\begin{tabular}{lcccccc}
\hline \hline & Project & Project & Project & Project & Project & \\
& $\mathbf{1}$ & $\mathbf{2}$ & $\mathbf{3}$ & $\mathbf{4}$ & $\mathbf{5}$ & Average \\
\hline Project Labor & $0.17 \%$ & $0.37 \%$ & $0.54 \%$ & $0.43 \%$ & $0.46 \%$ & $0.39 \%$ \\
Project Total & $0.11 \%$ & $0.24 \%$ & $0.35 \%$ & $0.28 \%$ & $0.30 \%$ & $0.26 \%$ \\
\hline
\end{tabular}

\subsection{Impact of Market Correction from Currently Depressed Wages}

Recall from the previous chapter, a wage depression of $11 \%$ due to immigrant penetration into the low-skilled construction occupations of concrete, masonry, drywall, painting, flooring, and roofing is assumed. Should immigration become more restrictive, the supply of immigrant labor dissipate, and native-born workers be substituted for their immigrant counterparts, given the findings of this research, a corresponding market correction could be anticipated. Application of equation (3) from chapter 4 accounts for almost a $4 \%$ increase in total labor costs and almost a 2.5\% increase in total project costs. A summary of these impacts is shown in Table 5.4 (Golden and Skibniewski, 2008a).

Table 5.4: Impact on Project Costs Due to Increase in Wages Resulting From Market Correction From Currently Depressed Wage Estimates

\begin{tabular}{lcccccc}
\hline \hline & Project & Project & Project & Project & Project & \\
& $\mathbf{1}$ & $\mathbf{2}$ & $\mathbf{3}$ & $\mathbf{4}$ & $\mathbf{5}$ & Average \\
\hline Project Labor & $1.66 \%$ & $3.64 \%$ & $5.31 \%$ & $4.19 \%$ & $4.51 \%$ & $3.86 \%$ \\
Project Total & $1.08 \%$ & $2.36 \%$ & $3.45 \%$ & $2.72 \%$ & $2.93 \%$ & $2.51 \%$ \\
\hline
\end{tabular}




\subsection{Impact of Labor Shortage}

From the regression model introduced in chapter 4 , if the demand for construction workers remains at 5,850,000 and the economy remains such that average worker wages remain at $\$ 17.50$ per hour, then a change in the number of job openings by 50,000 equates to a $0.1 \%$ change in the wages. In other words, if job openings increase by 50,000 , the construction worker wages increase by $0.1 \%$.

Illegal immigrants account for $14 \%$ of the construction worker population. The total construction worker population is approximately 7 million, so illegal immigrants make up about 1 million of the construction workers. If the illegal immigrants were eliminated from the workforce immediately, the industry might expect a $2 \%$ increase in wages in order to close the gap on the job openings created by the elimination of the illegal immigrant workers. Application of equation (15) to this case amounts to an increase in total labor costs of $0.7 \%$ and an increase in total project costs of $0.46 \%$. The summary of these impacts is shown in Table 5.5 (Golden and Skibniewski, 2008b).

\begin{tabular}{lcccccc}
\hline Table 5.5: Impact on Project Costs Due to Predicted Labor Shortage \\
\hline \hline & Project & Project & Project & Project & Project & \\
& $\mathbf{1}$ & $\mathbf{2}$ & $\mathbf{3}$ & $\mathbf{4}$ & $\mathbf{5}$ & Average \\
\hline Project Labor & $0.30 \%$ & $0.66 \%$ & $0.97 \%$ & $0.76 \%$ & $0.82 \%$ & $0.70 \%$ \\
Project Total & $0.20 \%$ & $0.43 \%$ & $0.63 \%$ & $0.49 \%$ & $0.53 \%$ & $0.46 \%$ \\
\hline
\end{tabular}

\subsection{The Combined Effect}

The combination of these effects will be affected by the legislation that eventually passes. There are 3 scenarios that are possible: 1) all illegal and "quasi-legal" immigrants are allowed to stay in the United States and continue working, 2) all 
illegal and "quasi-legal" immigrants eliminated from the workforce, or 3) somewhere in between. Scenarios 1 and 2 are the extreme cases, while scenario 3 is the most likely case. This evaluation will provide a view of the spectrum of possible impacts to the construction industry.

\subsubsection{Scenario 1 - All Illegal Immigrants Are Allowed to Stay}

In scenario 1, if all existing workers were allowed to continue, regardless of legal immigration status, the prevailing wage effect and the tax effect would apply. How many workers would be affected by the prevailing wage provision would depend on how many were given guest worker status as compared to legal permanent resident status. This assumption is based on the Comprehensive Immigration Reform Act of 2006, S.2611. Of the three bills discussed in this research, this bill is the most comprehensive, containing the prevailing wage, amnesty, and guest worker provisions most likely to affect the construction industry.

Recall that approximately $25 \%$ of the total population of illegal immigrants currently residing in the U.S. would be eligible for Deferred Mandatory Departure (DMD) as defined in the Senate Bill, S.2611, and thus eligible for the guest worker provision in the proposed legislation and the prevailing wages promised in the bill. Another $60 \%$ would be given LPR or citizenship status, leaving $15 \%$ undocumented immigrants without coverage under this legislation (Rector, 2006). So, if all of the illegal immigrants were allowed to stay, this would add an additional $15 \%$ to the $25 \%$ eligible for DMD status and thus eligible for the guest worker provision under this legislation. This assumes that all those eligible for LPR or citizenship status would apply and be granted this status. It follows then that, assuming 55\% of the 
construction workers in the immigrant-saturated trades are illegal immigrants means $22 \%$ of the total population of construction workers would be eligible for the prevailing wage provision.

Also recall that a tax compliance rate of $80 \%$ is assumed. So, it is estimated that $20 \%$ of illegal immigrant workers are paid "off the books." Assuming 55\% of the employees working in the immigrant-saturated trades are illegal immigrants means $11 \%$ of the population of construction workers is likely to be paid "off the books." Labor burden is estimated to be 10.2\%: $3.7 \%$ for workers' compensation insurance, $6.5 \%$ for unemployment insurance costs and for federal, state, and Social Security taxes. These are national averages for the construction industry based on BLS data (Bureau of Labor Statistics, 2007).

The combination of the prevailing wage provision in legislation and the requirement to pay labor burden on $100 \%$ of employees, given that they would all assume some sort of legal status would be up to a $15.5 \%$ increase in trade labor costs, a $4.13 \%$ increase in total labor costs and $2.69 \%$ increase in total project costs (see Table 5.6).

\begin{tabular}{|c|c|c|c|c|c|c|}
\hline & $\begin{array}{c}\text { Project } \\
1\end{array}$ & $\begin{array}{c}\text { Project } \\
2 \\
\end{array}$ & $\begin{array}{c}\text { Project } \\
\mathbf{3}\end{array}$ & $\begin{array}{c}\text { Project } \\
4\end{array}$ & $\begin{array}{c}\text { Project } \\
5\end{array}$ & Average \\
\hline Concrete & $15.40 \%$ & $12.18 \%$ & $15.40 \%$ & $7.86 \%$ & $15.40 \%$ & $13.25 \%$ \\
\hline Masonry & $3.05 \%$ & $2.83 \%$ & $3.05 \%$ & $-0.17 \%$ & $3.05 \%$ & $2.36 \%$ \\
\hline Drywall & $13.56 \%$ & $12.63 \%$ & $13.56 \%$ & $11.27 \%$ & $13.56 \%$ & $12.92 \%$ \\
\hline Terrazzo & $15.49 \%$ & $12.18 \%$ & $14.23 \%$ & $9.85 \%$ & $14.23 \%$ & $13.20 \%$ \\
\hline Painting & $14.23 \%$ & $10.18 \%$ & $6.13 \%$ & $10.57 \%$ & $6.13 \%$ & $9.45 \%$ \\
\hline Flooring & $6.13 \%$ & $2.53 \%$ & $11.03 \%$ & $3.72 \%$ & $11.03 \%$ & $6.89 \%$ \\
\hline Roofing & & $11.03 \%$ & & & & \\
\hline Project Labor & $2.16 \%$ & $3.22 \%$ & $6.16 \%$ & $3.08 \%$ & $6.03 \%$ & $4.13 \%$ \\
\hline Project Total & $1.40 \%$ & $2.10 \%$ & $4.01 \%$ & $2.00 \%$ & $3.92 \%$ & $2.69 \%$ \\
\hline
\end{tabular}


Again, this is assuming that employers are able to pay only those that are affected by the legislation the prevailing wage rate. If the prevailing wage applies to $100 \%$ of the labor costs for the immigrant-saturated trades in these projects, the increase in trade labor costs will be up to $66 \%$, the increase in total labor costs will be $17.38 \%$ and the increase in total project costs will be $11.3 \%$ (see Table 5.7).

\begin{tabular}{|c|c|c|c|c|c|c|}
\hline & $\begin{array}{l}\text { Project } \\
\quad 1\end{array}$ & $\begin{array}{c}\text { Project } \\
2\end{array}$ & $\begin{array}{c}\text { Project } \\
\mathbf{3}\end{array}$ & $\begin{array}{c}\text { Project } \\
4\end{array}$ & $\begin{array}{c}\text { Project } \\
5\end{array}$ & Average \\
\hline Concrete & $66.01 \%$ & $51.39 \%$ & $66.01 \%$ & $31.77 \%$ & $66.01 \%$ & $56.24 \%$ \\
\hline Masonry & $9.89 \%$ & $8.90 \%$ & $9.89 \%$ & $-4.77 \%$ & $9.89 \%$ & $6.76 \%$ \\
\hline Drywall & $57.67 \%$ & $53.45 \%$ & $57.67 \%$ & $47.23 \%$ & $57.67 \%$ & $54.74 \%$ \\
\hline Terrazzo & $66.44 \%$ & $51.39 \%$ & $60.69 \%$ & $40.81 \%$ & $60.69 \%$ & $56.00 \%$ \\
\hline Painting & $60.69 \%$ & $42.27 \%$ & $23.90 \%$ & $44.05 \%$ & $23.90 \%$ & $38.96 \%$ \\
\hline Flooring & $23.90 \%$ & $7.54 \%$ & $46.17 \%$ & $12.94 \%$ & $46.17 \%$ & $27.35 \%$ \\
\hline Roofing & & $46.17 \%$ & & & & \\
\hline Project Labor & $9.20 \%$ & $13.34 \%$ & $26.10 \%$ & $12.49 \%$ & $25.79 \%$ & $17.38 \%$ \\
\hline Project Total & $5.98 \%$ & $8.67 \%$ & $16.97 \%$ & $8.12 \%$ & $16.76 \%$ & $11.30 \%$ \\
\hline
\end{tabular}

\subsubsection{Scenario 2 - All Illegal Immigrants Are Forced from the Workforce}

In scenario 2, if by enforcement of current immigration laws or implementation of new laws, all illegal immigrant workers were deported or forced out of the workforce, the tax effect, market correction effect from currently depressed wages due to immigrant penetration into the workforce, and the labor shortage effect would apply. The tax compliance rate would theoretically be $100 \%$ since it is far less likely that legal immigrants or native-born workers would be paid "off-the-books." While tax fraud will always exist under our current system of laws, total tax compliance is assumed for this scenario. If new legislation restricts further immigration, then the 
market correction effect from currently depressed wages due to immigrant penetration into the workforce would apply from having to replace formerly immigrant labor with native-born workers. Recall that because immigrant penetration into the low-skilled construction occupations of concrete, masonry, drywall, painting, flooring, and roofing there is an estimated $11 \%$ reduction in wages for these trades.

Additionally, in this scenario, we would expect a labor shortage as illegal immigrant workers are replaced with legal immigrant or native-born workers. Illegal immigrants account for $14 \%$ of the construction worker population. The total construction worker population is approximately 7 million, so illegal immigrants make up about 1 million of the construction workers. If the illegal immigrants were eliminated from the workforce immediately, the industry might expect a $2 \%$ increase in wages in order to close the gap on the job openings created by the elimination of the illegal immigrant workers. This estimate is from the multiple regression analysis executed in the previous chapter.

The combination of these effects on construction project costs becomes a $14.12 \%$ increase in trade labor costs, a 5\% increase in total labor costs, and a 3.22\% increase in total project costs (see Table 5.8).

Table 5.8: Scenario 2 Impact on Project Costs

\begin{tabular}{lcccccc}
\hline \hline & Project & Project & Project & Project & Project & \\
& $\mathbf{1}$ & $\mathbf{2}$ & $\mathbf{3}$ & $\mathbf{4}$ & $\mathbf{5}$ & Average \\
\hline Project Labor & $2.13 \%$ & $4.67 \%$ & $6.81 \%$ & $5.38 \%$ & $5.79 \%$ & $4.96 \%$ \\
Project Total & $1.38 \%$ & $3.04 \%$ & $4.43 \%$ & $3.49 \%$ & $3.76 \%$ & $3.22 \%$ \\
\hline
\end{tabular}




\subsubsection{Scenario 3 - Somewhere in Between}

In scenario 3, some version of immigration reform legislation would pass, and some combination of impacts would affect construction project costs. For this evaluation, the Senate bill, Comprehensive Immigration Reform Act of 2006, S.2611 is assumed. Of the three bills discussed in this research, this bill is the most comprehensive, containing the prevailing wage, amnesty, and guest worker provisions most likely to affect the construction industry.

As a result of this legislation, approximately $25 \%$ of the total population of illegal immigrants currently residing in the U.S. would be eligible for Deferred Mandatory Departure (DMD) as defined in the Senate Bill, S.2611, and thus eligible for the guest worker provision in the proposed legislation and the prevailing wages promised in the bill (Rector, 2006). In this case, assuming 55\% of the construction workers in the immigrant-saturated trades are illegal immigrants, then $14 \%$ of the total population of construction workers would be eligible for the prevailing wage provision.

Also recall that a tax compliance rate of $80 \%$ is assumed. So, it is estimated that $20 \%$ of illegal immigrant workers are paid "off the books." Assuming 55\% of the employees working in the immigrant-saturated trades are illegal immigrants means $11 \%$ of the population of construction workers is likely to be paid "off the books." Labor burden is estimated to be $10.2 \%: 3.7 \%$ for workers' compensation insurance, $6.5 \%$ for unemployment insurance costs and for federal, state, and Social Security taxes. These are national averages for the construction industry based on BLS data (Bureau of Labor Statistics, 2007). 
Illegal immigrants account for $14 \%$ of the construction worker population. The total construction worker population is approximately 7 million, so illegal immigrants make up about 1 million of the construction workers. Under the Senate bill, Comprehensive Immigration Reform Act of 2006, S.2611, approximately 60\% of illegal immigrants would be eligible for amnesty and citizenship (Rector, 2006). Taking into account the other $25 \%$ eligible for DMD, only $15 \%$ of illegal immigrants would be forced from the workforce. This equals approximately 400,000 workers. Using the model from the previous chapter, 400,000 job openings correlates to a $0.8 \%$ increase in worker wages in immigrant-saturated trades.

Thus, the combination of these effects on construction project costs results in up to an $11 \%$ increase in trade labor costs, a $3 \%$ increase in total labor costs, and a $2 \%$ increase in total project costs (see Table 5.9).

Table 5.9: Scenario 3 Impact on Project Costs with Prevailing Wage Provision Applied Only to Illegal Immigrant Labor

\begin{tabular}{lcccccc}
\hline \hline & Project & Project & Project & Project & Project & \\
& $\mathbf{1}$ & $\mathbf{2}$ & $\mathbf{3}$ & $\mathbf{4}$ & $\mathbf{5}$ & Average \\
\hline Concrete & $10.84 \%$ & $8.83 \%$ & $10.84 \%$ & $6.14 \%$ & $10.84 \%$ & $9.50 \%$ \\
Masonry & $3.13 \%$ & $2.99 \%$ & $3.13 \%$ & $1.11 \%$ & $3.13 \%$ & $2.70 \%$ \\
Drywall & $9.70 \%$ & $9.12 \%$ & $9.70 \%$ & $8.26 \%$ & $9.70 \%$ & $9.29 \%$ \\
Terrazzo & $10.90 \%$ & $8.83 \%$ & $10.11 \%$ & $7.38 \%$ & $10.11 \%$ & $9.47 \%$ \\
Painting & $10.11 \%$ & $7.58 \%$ & $5.05 \%$ & $7.82 \%$ & $5.05 \%$ & $7.13 \%$ \\
Flooring & $5.05 \%$ & $2.80 \%$ & $8.12 \%$ & $3.55 \%$ & $8.12 \%$ & $5.53 \%$ \\
Roofing & & $8.12 \%$ & & & & \\
Project Labor & $1.53 \%$ & $2.42 \%$ & $4.44 \%$ & $2.39 \%$ & $4.27 \%$ & $3.01 \%$ \\
Project Total & $1.00 \%$ & $1.57 \%$ & $2.89 \%$ & $1.55 \%$ & $2.78 \%$ & $1.96 \%$ \\
\hline
\end{tabular}

Again, this is assuming that employers are able to pay the prevailing wage rate only to those that are affected by the legislation. If the prevailing wage applies to $100 \%$ of the labor costs for the immigrant-saturated trades in these projects, the trade labor 
costs increase up to $67 \%$, the total labor costs increase $17.67 \%$, and the total projects costs increase $11.48 \%$ (see Table 5.10).

Table 5.10: Scenario 3 Impact on Project Costs with Prevailing Wage Provision Applied to All Labor for Immigrant-Saturated Trades

\begin{tabular}{lcccccc} 
& Project & Project & Project & Project & Project & \\
& $\mathbf{1}$ & $\mathbf{2}$ & $\mathbf{3}$ & $\mathbf{4}$ & $\mathbf{5}$ & Average \\
\hline Concrete & $66.81 \%$ & $52.19 \%$ & $66.81 \%$ & $32.57 \%$ & $66.81 \%$ & $57.04 \%$ \\
Masonry & $10.69 \%$ & $9.70 \%$ & $10.69 \%$ & $-3.97 \%$ & $10.69 \%$ & $7.56 \%$ \\
Drywall & $58.47 \%$ & $54.25 \%$ & $58.47 \%$ & $48.03 \%$ & $58.47 \%$ & $55.54 \%$ \\
Terrazzo & $67.24 \%$ & $52.19 \%$ & $61.49 \%$ & $41.61 \%$ & $61.49 \%$ & $56.80 \%$ \\
Painting & $61.49 \%$ & $43.07 \%$ & $24.70 \%$ & $44.85 \%$ & $24.70 \%$ & $39.76 \%$ \\
Flooring & $24.70 \%$ & $8.34 \%$ & $46.97 \%$ & $13.74 \%$ & $46.97 \%$ & $28.15 \%$ \\
Roofing & & $46.97 \%$ & & & & \\
Project Labor & $9.32 \%$ & $13.60 \%$ & $26.49 \%$ & $12.79 \%$ & $26.12 \%$ & $17.67 \%$ \\
Project Total & $6.06 \%$ & $8.84 \%$ & $17.22 \%$ & $8.32 \%$ & $16.98 \%$ & $11.48 \%$ \\
\hline
\end{tabular}

Table 5.11 shows the impact of legislation similar to the Senate bill, Comprehensive Immigration Reform Act of 2006, S.2611, without the prevailing wage provision. In this final scenario, only the tax effect and labor shortage effect are considered.

Table 5.11: Scenario 3 Impact on Project Costs without Prevailing Wage Provision

\begin{tabular}{lcccccc}
\hline \hline & Project & Project & Project & Project & Project & \\
& $\mathbf{1}$ & $\mathbf{2}$ & $\mathbf{3}$ & $\mathbf{4}$ & $\mathbf{5}$ & Average \\
\hline Project Labor & $0.29 \%$ & $0.64 \%$ & $0.93 \%$ & $0.73 \%$ & $0.79 \%$ & $0.67 \%$ \\
Project Total & $0.19 \%$ & $0.41 \%$ & $0.60 \%$ & $0.48 \%$ & $0.51 \%$ & $0.44 \%$ \\
\hline
\end{tabular}

The assumption used in the above estimates was that labor costs equal approximately $65 \%$ of total project costs. This assumption is typical for construction projects in the Washington, D.C. area. However, if the methodologies presented here are to be transferred to another geographic region, this assumption should be reexamined. 
Differing economic conditions will impact the proportion of labor costs to total project costs.

\subsection{Chapter Summary}

Chapter 5 has presented a practical application of the methodologies from Chapter 4 . A detailed analysis was conducted on cost data for five construction projects: three high-rise office buildings, one high-rise condominium, and one institutional construction project (see Table 3.1). The projects ranged in cost from $\$ 55$ million to $\$ 800$ million. The projects were all from Washington D.C. metropolitan area. There were four factors evaluated that would influence construction project costs in the wake of immigration reform: 1) prevailing wage provision, 2) forced tax compliance, 3) market correction from currently depressed wages resulting from immigrantpenetration into the workforce, and 4) a labor shortage resulting from a depleted supply of immigrant labor.

Table 5.12 presents a summary of these impacts. 


\begin{tabular}{|c|c|c|c|}
\hline Factor & $\begin{array}{l}\text { Impact to } \\
\text { Trade } \\
\text { Labor Costs }\end{array}$ & $\begin{array}{l}\text { Impact to } \\
\text { Total } \\
\text { Labor } \\
\text { Costs }\end{array}$ & $\begin{array}{l}\text { Impact to } \\
\text { Total } \\
\text { Project } \\
\text { Costs }\end{array}$ \\
\hline $\begin{array}{l}\text { Prevailing Wage - Provision Applied to } \\
\text { Illegal Immigrants Only }\end{array}$ & $9 \%$ & $2.34 \%$ & $1.52 \%$ \\
\hline $\begin{array}{l}\text { Prevailing Wage - Provision Applied to } \\
\text { All Workers in Immigrant-Saturated } \\
\text { Trades }\end{array}$ & $65 \%$ & $17 \%$ & $11 \%$ \\
\hline Forced Tax Compliance & $1.12 \%$ & $0.39 \%$ & $0.26 \%$ \\
\hline $\begin{array}{l}\text { Market Correction from Currently } \\
\text { Depressed Wages }\end{array}$ & $11 \%$ & $3.86 \%$ & $2.51 \%$ \\
\hline Labor Shortage & $2 \%$ & $0.70 \%$ & $0.46 \%$ \\
\hline $\begin{array}{l}\text { Scenario 1, Alternative } 1 \text { - All Illegal } \\
\text { Immigrants are Allowed to Stay; } \\
\text { Prevailing Wage Provision Applied to } \\
\text { Illegal Immigrants Only }\end{array}$ & $15.49 \%$ & $4.13 \%$ & $2.69 \%$ \\
\hline $\begin{array}{l}\text { Scenario 1, Alternative } 2 \text { - All Illegal } \\
\text { Immigrants are Allowed to Stay; } \\
\text { Prevailing Wage Provision Applied to All } \\
\text { Workers in Immigrant-Saturated Trades }\end{array}$ & $66 \%$ & $17.38 \%$ & $11.3 \%$ \\
\hline $\begin{array}{l}\text { Scenario } 2 \text { - All Illegal Immigrants are } \\
\text { Eliminated from the Workforce }\end{array}$ & $14.12 \%$ & $5 \%$ & $3.22 \%$ \\
\hline $\begin{array}{l}\text { Scenario 3, Alternative } 1 \text { - Immigration } \\
\text { Reform Bill Passed Similar to } \\
\text { Comprehensive Immigration Reform Act } \\
\text { of 2006; Prevailing Wage Provision } \\
\text { Applied to Illegal Immigrants Only }\end{array}$ & $11 \%$ & $3 \%$ & $2 \%$ \\
\hline $\begin{array}{l}\text { Scenario 3, Alternative } 2 \text { - Immigration } \\
\text { Reform Bill Passed Similar to } \\
\text { Comprehensive Immigration Reform Act } \\
\text { of 2006; Prevailing Wage Provision } \\
\text { Applied to All Workers in Immigrant- } \\
\text { Saturated Trades }\end{array}$ & $67 \%$ & $17.67 \%$ & $11.48 \%$ \\
\hline $\begin{array}{l}\text { Scenario 3, Alternative } 3 \text { - Immigration } \\
\text { Reform Bill Passed Similar to } \\
\text { Comprehensive Immigration Reform Act } \\
\text { of 2006; No Prevailing Wage Provision }\end{array}$ & $1.92 \%$ & $0.67 \%$ & $0.44 \%$ \\
\hline
\end{tabular}


Of the three scenarios analyzed, the third scenario is probably the most realistic. Some version of immigration reform is likely to pass eventually. Even in the absence of immigration reform legislation, the immigrant supply of labor is likely to decrease to some extent based on increased enforcement of existing laws. So, some combination of the four factors analyzed in this research will influence construction project costs in the wake of immigration reform. While a large general contractor may be able to absorb the increase in total costs for its projects, it is unlikely that trade subcontractors could absorb a 11-67\% increase in labor costs. Therefore, trade subcontractors would be most adversely affected by immigration reform legislation or increased enforcement of existing immigration laws.

If a prevailing wage provision is not included in the legislation, then only a $2 \%$ increase in trade labor, a $1 \%$ increase in total project labor costs, and a $0.5 \%$ increase in total project costs could be expected. This appears sustainable for the large commercial construction industry.

When the impacts are isolated, the prevailing wage provision and the market correction effect from currently depressed wages due to immigrant penetration into the workforce effect from immigrant penetration into the workforce are seen to have the most influence on project costs.

The model constructed in the previous chapter attempts to relate the job openings reported in the construction industry, an indicator of a labor shortage, to the wage paid to the construction workers. There does not seem to be a strong correlation. This seems to indicate that the industry does not respond to an apparent shortage by raising wages to attract workers. It may also be that the industry has an adequate 
supply of workers, which is supported by the unemployment rate for the construction industry being consistently higher than the national unemployment rate average. In these low-skilled occupations, there is a high substitutability for labor. Thus, a true shortage would be difficult to induce. Adding resources is not the only way to make up for an apparent labor shortage. The industry may also respond by extending the project durations or by replacing labor with technology. Additional research is required in this area to examine how industry responds to labor shortages. At any rate, the labor shortage effect analyzed here has little impact on construction project costs.

It is unlikely that all illegal immigrants will be entirely forced from the workforce. However, if enforcement of immigration laws continues to increase, the industry may experience some of the impact described in scenario 2 . While a $3 \%$ increase in project costs may be sustainable from the general contractor's perspective, a $14 \%$ increase in trade labor costs would be detrimental for the subcontractors. In the final chapter, conclusions from this data will be drawn and recommendations made in order to mitigate these effects. 


\section{Chapter 6: Conclusions and Recommendations}

Immigration has been a topic of legislation since the founding of the United States of America, the first of which was the U.S. Constitution, followed shortly after by The Naturalization Act of 1790. The debate is not over. Immigration reform was at the forefront of the election issues in 2006 and will continue to be a controversial and intense topic of discussion across America. Regardless of the scope of the final immigration reform bill passed in Congress and even in absence of such legislation, the construction industry is experiencing and will continue to experience stricter enforcement of existing immigration laws that prohibit employment of illegal immigrants. This is certain to impact the labor supply of the construction industry, where an estimated 14\% of the workforces are illegal immigrants (Passel, 2006).

The legislation that finally materializes is likely to include both enforcement and amnesty provisions. The elements of pending legislation that will have the most significant impact on the construction industry will include the mandated use of the Employment Eligibility Verification System, more stringent enforcement and harsher penalties for document fraud and employment of illegal immigrants, amnesty for many illegal immigrants currently residing in the U.S., and the guest worker provision.

The construction industry is heavily dependent on immigrant labor, legal and illegal, for production. The threat of reduction in that supply has generated broad speculation on the impact of immigration reform legislation by industry executives. This research was in direct response to these industry concerns. 


\subsection{Contributions of the Research}

The literature on immigration and impacts of immigration on the economy is vast but broad. Most of the literature addresses these influences on the national level across all industries. There has been speculation on the impact of immigration reform legislation, but no empirical methods have been established in order to quantify these impacts. This research proposes a methodology to estimate the impacts of immigration reform legislation specifically on construction project costs for a defined geographic region. In particular, it addresses two voids in existing literature: the estimate of illegal immigrants working on commercial construction projects in the Washington, D.C. area and the impact of immigration reform legislation on construction project costs in the same area.

In response to research questions: how many illegal immigrants are employed in construction within this specific geographic area and how does this differ from national estimates, a survey instrument was modified from existing research and implemented across the Washington, D.C. metropolitan region. This was the first such research conducted in this area in order to discern the proportion of illegal immigrant to legal immigrant and native-born workers in construction. The results of the research revealed approximately 55\% of construction workers in this region are illegal immigrants.

Next, there were four impacts of immigration and immigration reform legislation on worker wages and construction project costs identified and evaluated: 1) prevailing wage provision in legislation, 2) forced tax compliance of the workforce, 3) market correction from currently depressed wages resulting from immigrant penetration into 
the workforce, and 4) a labor shortage resulting from a depleted supply of immigrant labor. The first three factors were addressed using algebraic models defined in Chapter 4. The labor shortage impact was modeled with a multiple linear regression model, also in Chapter 4.

Also in response to the research questions and aligned with the objectives of this research, impacts 1 and 2 answered the question of how guest worker provisions and prevailing wage determinations would affect construction project costs. Impact 3, market correction from currently depressed wages resulting from immigrant penetration into the workforce addressed the differential between native-born worker and illegal immigrant wages and evaluated the increase in wages should illegal immigrant workers be replaced by native-born workers. Impact 4 addressed the impact on wages resulting from a decreased supply of immigrant workers.

Finally, the impacts described in Chapter 4 were examined across five construction projects from the Washington, D.C. metropolitan area in order to demonstrate the application and to give reasonable estimates of these impacts for this geographic region.

The methods developed in this research provide an important tool for industry to evaluate the impact of immigration and immigration reform legislation in particular on construction project costs. This information is widely sought in the construction management field. While there is much research on the impact of immigration on society and the economy, this is the first such work strictly related to the construction project management field. 


\subsection{Limitations of the Research}

The results of this research reveal approximately 55\% undocumented and "quasilegal" immigrant workers in construction in the Washington, D.C. metropolitan area, with an estimated $22 \%$ being truly undocumented. Because random sampling of the immigrant population of construction workers across the geographic region is not possible, a representative sample could not be drawn from this data. Extrapolation of the quantitative survey results to the universe of construction workers in the Washington, D.C. metropolitan area requires judgment. Thus, the conclusions drawn from the survey data are provisional; however, they are strongly supported by this and other research.

The sample for this research comes from a large concrete subcontractor in the Washington, D.C. metropolitan area, a subsidiary of a large general contractor operating nationally. Therefore, the strongest correlations between this data and data for the geographic region will be with companies working in commercial construction on similar-sized projects with similar hiring practices. Where these similarities exist, inferences about the characteristics of the immigrant workforce in construction may be drawn.

Contributing to the problem of random sampling was the apprehension of employers to allow their employees to participate in the survey. Many trade contractors in the area refused participation likely from a fear of being caught employing known illegal immigrants or a fear of losing illegal workers through legal action. It proved much more difficult to persuade company participation than to persuade individual participation once access to the workforce has been accomplished. 
Literacy among the respondents was also a major factor in the implementation of this survey. Due to the dismal literacy rate among employees, most of the surveys were administered personally to groups of 1-2 employees at a time. Illiteracy was not anticipated to be as prevalent as was discovered. This significantly slowed the survey progress, as generally no more than 50 employees could be interviewed in a day.

Additionally, changing immigration reform proposals made it difficult to compose timely, relevant measures of the impacts. Timing is a critical factor in the purpose of this research; later studies will be an evaluation and not a prediction of the impacts proposed here.

The predictive nature of the study demanded several critical assumptions be made. The first was the form of the legislation that will be passed. In order to compensate for this lack of information, three possible scenarios were evaluated; two extreme cases and one more moderate example. Another assumption was the proportion of labor cost to total project costs. The assumption appropriate for this geographic region may not transfer to other areas with differing economic conditions. Should the study methodologies be transferred to a different geographic area, then these assumptions should be reexamined before applying them to differing circumstances.

\subsection{Implications for the Construction Industry}

The construction industry has been apprehensive of immigration reform evidenced by the interest in this research and their strong lobbying effort in Congress. From an industry perspective, it is advantageous to increase the current flow of immigrant labor, as long as the prevailing wage provision is never passed into legislation. 
If industry is successful in keeping a prevailing wage provision out of legislation, then only a $2 \%$ increase in trade labor costs, a $0.67 \%$ increase in total project labor costs, and a $0.44 \%$ increase in total project costs could be expected. This appears sustainable for the large commercial construction industry.

When the impacts are isolated, the prevailing wage provision and the market correction from currently depressed wages due to immigrant penetration into the workforce are seen to have the most influence on project costs. The prevailing wage provision is overcome by preventing the legislation. The market correction effect is eliminated by maintaining the supply of immigrant labor. If immigrant labor stays a strong force in the labor market, then native-born substitute labor will not be required and the market correction will be staved off.

The labor shortages feared by the industry will not have the impact anticipated. The unemployment rate for the construction industry is consistently higher than the national unemployment rate average. This would indicate an availability of workers. Additionally, in these low-skilled occupations, there is a high substitutability for labor. Thus, a true shortage would be difficult to induce. This is further supported by this research and the labor shortage model presented in Chapter 4.

It is unlikely that all illegal immigrants will be forced from the workforce. However, if enforcement of immigration laws continues to increase, the industry may experience some of the impact described in scenario 2. While a $3 \%$ increase in project costs may be sustainable from the general contractor's perspective, a $14 \%$ increase in trade labor costs would be detrimental for the subcontractors. In order to avoid increases from this influence, it would be beneficial for trade contractors that 
employ large populations of immigrants to begin exploring technology investments that save in labor effort. These types of innovative methods in automation would eliminate the industry's dependence to some extent on immigrant labor. It is surprising to note that there have been few advances in construction processes and production in the last 30 years. Technological advancements like those that have historically revamped the manufacturing industry have failed to take shape within the construction industry. However, Japan and Europe have several construction automation technologies that would be easily transferred to the U.S. Several robotic developments have been made in concrete placement and finishing that save in labor requirements and increase the safety and productivity of the workers.

\subsection{Further Research}

There are several aspects of immigration and its impact on the construction industry revealed in this research that warrant further study.

- While the direct impacts of the prevailing wage provision were included here, inflationary impacts on construction projects and costs were not addressed. This subject has been examined previously, but in light of the possible extension of the Davis-Bacon Act by immigration reform legislation, additional study is warranted.

- This research relied on previous studies for information on expected tax compliance among illegal immigrants. The tax laws have changed since the most recent published study. The effect of these changes on compliance rates may also be a topic of future research. 
- There is likely some impact on illegal immigrant wages associated with the risk the employer faces in hiring unauthorized workers. How this risk affect the decision to hire unauthorized workers, the effect on worker wages, and implications on the decision of the illegal immigrant to immigrate to the U.S. may be analyzed further.

- This research held all other economic factors that affect wages and construction project costs constant and directed the study at the impact of immigration and immigration reform legislation. Additional research is required to address these other influences in conjunction with this study. 


\section{Appendix A: Survey Instrument \\ Construction Industry Labor Resources Survey}

This survey is part of a construction industry labor resources research project at the University of Maryland. Participants in this survey will remain anonymous. This survey does not affect employment or immigration status in any way. The primary purpose of this research is education and results will remain confidential.

1. Detailed Occupation: Pick the category that best fits your type of work.

a. First line supervisor/managers of construction trades

b. Brick masons, block masons, and stone masons

c. Carpenters

d. Carpet, floor, and tile installers and finishers

e. Cement masons, concrete finishers, and terrazzo workers

f. Construction laborers

g. Construction equipment operators

h. Drywall installers, ceiling tile installers and finishers

i. Electricians

j. Painters

k. Pipe layers, plumbers, pipe fitters, and steam fitters

I. Roofers

m. Sheet metal workers

n. Structural iron and steel workers

o. Helpers

p. Inspectors

q. Glaziers

r. Waterproofers

s. Field Engineer

2. Sex: $\mathbf{M} \mathbf{F}$

3. Date of birth:

4. Are you a U.S. Citizen? If yes, go to question 7 . 
5. Are you a legal permanent resident (LPR) with a valid green card?

If no, go to question 6 .

\section{$\mathbf{Y} \quad \mathbf{N}$}

a. How did you receive your legal permanent residence? Which program?

1. Immigration Reform and Control Act of 1986 (IRCA)

a. LAW (Legally Authorized Worker)

b. SAW (Special Agricultural Worker)

2. Nicaraguan Adjustment and Central American Relief Act of 1997 (NACARA)

3. Dependent/Family Member

4. Work Sponsor

5. Other program

6. Are you a non-immigrant visa holder (NIV)?

$\mathbf{Y} \quad \mathbf{N}$

7. Country of birth:

If you were born in the United States, go to question 9.

8. What year did you arrive in the United States?

9. Highest education level:
a. Did not graduate high school
b. High school graduate or equivalent
c. College

10. Do you receive any of the following government benefits: $\mathbf{Y}$

$\mathbf{N}$

If so, which ones?

d. Social Security Benefits

e. Temporary Assistance to Needy Families (TANF)

f. Supplemental Security Benefits

g. Medicaid

11. Are you a veteran of the armed forces of the United States? $\mathbf{Y}$

$\mathbf{N}$

If so, do you receive veteran's benefits?

$\mathbf{Y} \quad \mathbf{N}$ 
12. Which of the following categories represents your total income for the last 12 months?

\begin{tabular}{|l|l|}
\hline a. Less than $\$ 5,000$ & i. $\$ 30,000$ to 34,999 \\
\hline b. $\$ 5,000$ to 7,499 & j. $\$ 35,000$ to 39,999 \\
\hline c. $\$ 7,500$ to 9,999 & k. $\$ 40,000$ to 49,999 \\
\hline d. $\$ 10,000$ to 12,499 & I. $\$ 50,000$ to 59,999 \\
\hline e. $\$ 12,500$ to 14,999 & m. $\$ 60,000$ to 74,999 \\
\hline f. $\$ 15,000$ to 19,999 & n. $\$ 75,000$ to 99,999 \\
\hline g. $\$ 20,000$ to 24,999 & o. $\$ 100,000$ to 149,000 \\
\hline h. $\$ 25,000$ to 29,999 & p. $\$ 150,000$ or more \\
\hline
\end{tabular}

13. Did you do any temporary, part-time, or seasonal work even for a few days during the last 12 months?

$\mathbf{Y} \quad \mathbf{N}$

14. How many months did you work in the last 12 months?

15. How many hours do you usually work in a week?

a. If less than 40 hours per week, what is the main reason?

1. Could not find full time job

2. Wanted to work part time or only able to work part time

3. Slack work or material shortage or weather

4. Other reason:

16. What is your hourly wage?

17. Are you eligible to participate in your company's or union's health insurance program? Y N

b. Do you participate?

Y $\quad \mathbf{N}$

18. Are you eligible to participate in your company's 401 (K), union, or other retirement program?

$\mathbf{Y} \quad \mathbf{N}$

c. Do you participate?

Y N 
19. Do you receive paid vacation benefits?

Y N

If so, how much per year?

20. Do you receive sick pay benefits?

$\mathbf{Y} \quad \mathbf{N}$

If so, how much per year?

21. Did you receive assistance in reading or writing for this survey?

Y N 
The card below shows different categories of immigration status. Choose the letter of the ONE BOX that best describes your current status. Do not pick a single category from a box. Circle the letter of the box that best describes your current status.

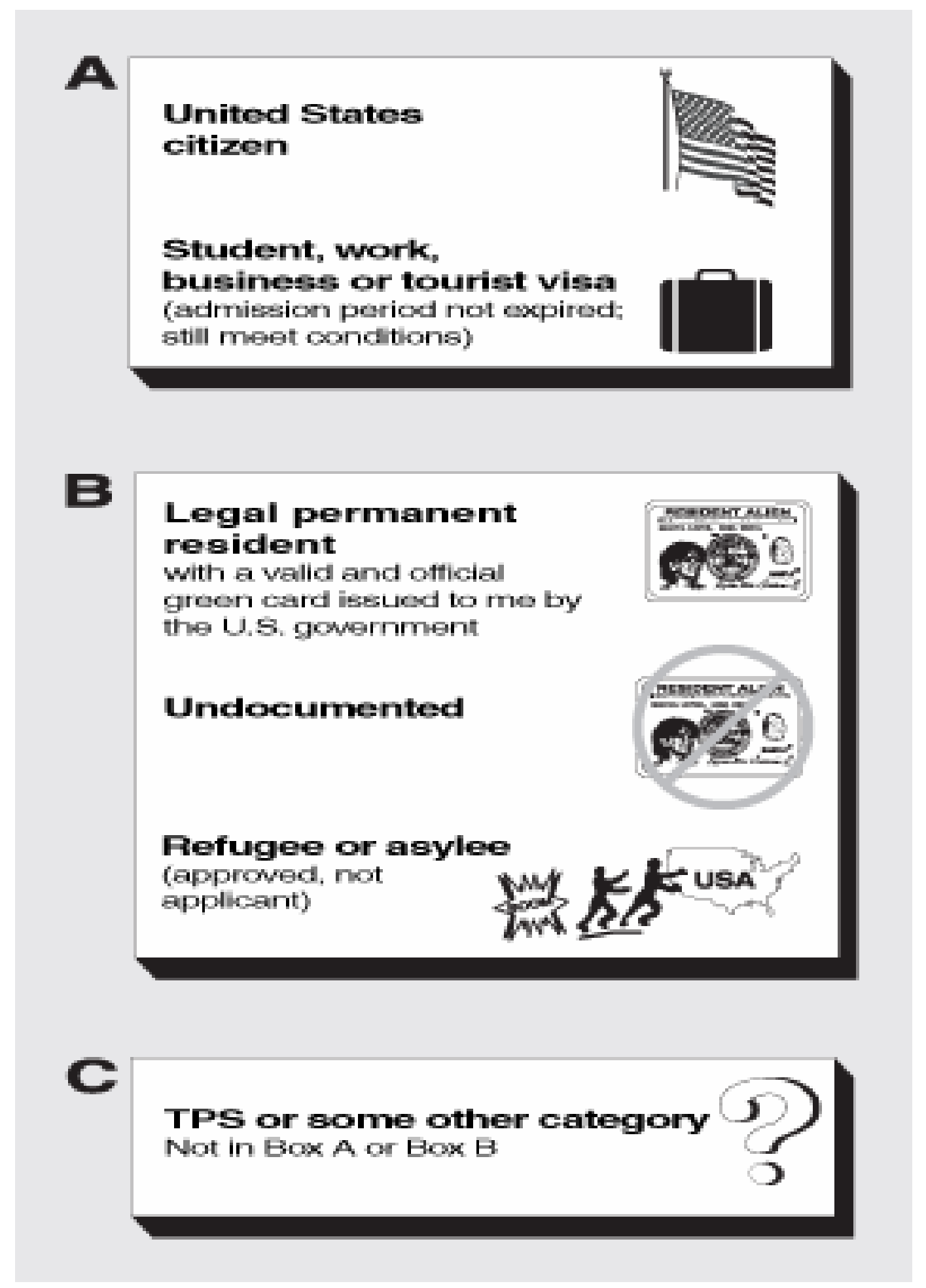




\section{Encuesta de los Recursos Laborales en la Industria de la Construcción}

Esta encuesta es parte de un proyecto de la industria laboral de la construcción conducido por la Universidad de Maryland. Los participantes en este censo permanecerán anónimos. Este cuestionario no afecta su empleo o estado migratorio. El propósito primario de este proyecto es educativo y los resultados permanecerán confidenciales.

1. Ocupación: Elija una opción que mejor describa su tipo de trabajo.

a. Supervisor/gerente de construcción

b. Albañiles, albañiles de bloques, y albañiles de piedra

c. Carpinteros

d. Instaladores de alfombra, piso, e instaladores de cerámica y terminadores

e. Trabajadores de cemento, afinadores de concreto, y trabajadores en terrazo o mármol

f. Peónes de construcción

g. Operadores de equipo pesado de construcción

h. Instaladores de drywall, techo y terminadores

i. Electricistas

j. Pintores

k. Instaladores de tuberías, plomeros, fontaneros, montador de calderas a vapor

I. Trabajadores de techo

m. Hojalateros

n. Trabajadores de hierro estructural y Herreros

o. Ayudantes

p. Inspectores

q. Vidriero

r. Impermeabilizar

s. Ingenieros de obra

2. Su sexo: $\mathbf{M} \mathbf{F}$

3. Fecha de nacimiento:

4. ¿Es usted un ciudadano de los Estados Unidos?

Si

No Si la respuesta a la pregunta anterior fue $\mathrm{Si}$, vaya a la pregunta 7. 
5. ¿Es usted un extranjero residente legal con una tarjeta válida y oficial? También le llaman "green card."

Si

No

Si la respuesta a la pregunta anterior fue No, vaya a la pregunta 6 .

a. ¿Cómo recibió su residencia legal? ¿Cuál programa?

1. Ley de Reforma de Inmigración y Control de 1986 (IRCA)

a. SAW (Trabajador especial de agricultura)

b. LAW ( Trabajador legalmente autorizado)

2. Nicaraguan Adjustment and Central American Relief Act of 1997 (NACARA)

3. Dependiente/Familiar

4. Por trabajo

5. Otro programa

6. ¿Tiene visado de non-inmigrante (NIV)?

Si

No

7. Lugar de nacimiento (el pais):

Si nació en los Estados Unidos, vaya a la pregunta 9.

8. ¿En que año llegó a los Estados Unidos?

9. Máximo nivel de educación:

a. No graduado de enseñanza secundaria

b. Enseñanza secundaria graduado o equivalente

c. Colegio

10. ¿Recibe algún beneficio del gobierno: Si No

¿Si la requesta a la pregunta anterior fue Si, cuál programas?

d. Beneficio de Seguro Social

e. Ayuda Provisional para Familias Necesitadas (TANF)

f. Beneficios Suplementales del Seguro Social

g. Medicaid

11. ¿Es un veterano de las fuerzas armadas de los Estados Unidos?

Si No

¿Recibe beneficios de veteranos? Si No 
12. ¿Cuál categoría representa sus ingresos totales por los últimos 12 meses?

\begin{tabular}{|l|l|}
\hline a. Menos de $\$ 5,000$ & i. $\$ 30,000$ a 34,999 \\
\hline b. $\$ 5,000$ a 7,499 & j. $\$ 35,000$ a 39,999 \\
\hline c. $\$ 7,500$ a 9,999 & k. $\$ 40,000$ a 49,999 \\
\hline d. $\$ 10,000$ a 12,499 & l. $\$ 50,000$ a 59,999 \\
\hline e. $\$ 12,500$ a 14,999 & m. $\$ 60,000$ a 74,999 \\
\hline f. $\$ 15,000$ a 19,999 & n. $\$ 75,000$ a 99,999 \\
\hline g. $\$ 20,000$ a 24,999 & o. $\$ 100,000$ a 149,000 \\
\hline h. $\$ 25,000$ a 29,999 & p. $\$ 150,000$ o más \\
\hline
\end{tabular}

13. ¿Hizo algún trabajo provisional, de medio-tiempo, o trabajo temporal por pocos días en los últimos 12 meses?

Si No

14. ¿Cuántos meses trabajó por los últimos12 meses?

15. ¿Cuántas horas por semana trabaja normalmente?

d. ¿Si menos de 40 horas por semana, cual es la causa principal?

1. No encuentra trabajo a tiempo completo

2. Quiere trabajar medio-tiempo o solamente es capaz trabajar medio-tiempo

3. No hay mucho trabajo, falta de materiales o mal tiempo

4. Otra razón:

16. ¿Cual es su salario por hora?

17. ¿Es elegible para participar en el programa de seguro médico de su compañía o sindicato?

\section{Si No}
e. ¿Participa?
Si No

18. ¿Es elegible para participar en el programa de retiro o plan de $401(\mathrm{~K})$ de su compañía o sindicato?

\section{Si No}
f. ¿Participa?
Si No 
19. ¿Recibe beneficios de vacación?

Si No ¿Si la respuesta a la pregunta anterior fue $\mathrm{Si}$, cuánto por año?

20. ¿Recibe beneficios por enfermedad?

Si No ¿Si la respuesta a la pregunta anterior fue $\mathrm{Si}$, cuánto por año?

21. ¿Recibió ayuda para leer o escribir esta encuesta?

Si No 
La tarjeta de abajo describe categorias de estado de inmigración diferente. Elige UNA LETRA que describe mejor su presente estado migratorio. No elige una sola catagoria de la casilla. Haga un círculo en la letra de la casilla describa mejor su estado presente.

Extranjero residente legal

con una tarjeta válida y official (tambien le llaman "green card" expedida a mi por el gobierno de los Estados Unidos

Refugiado o asilado Sin "green card"

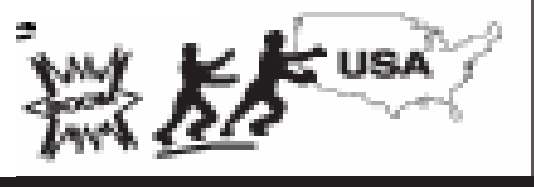

\section{Unidos}

B Ciudadano de los Estados

Visa de estudiante, de trabajo, 0 de turista (período de admission no vencido)
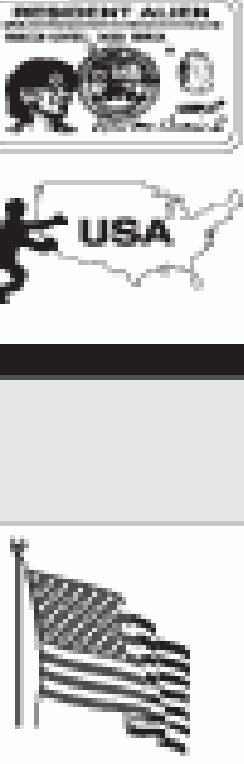

$$
\text { (periodo de admission no vencido) }
$$

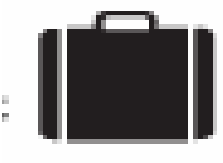

Indocumentado

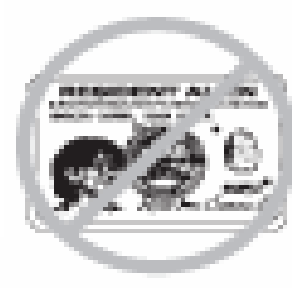

Programa de protección temporal (TPS) u otra categoría Que no se encuentra en A o B (especifique) 
Appendix B: Data for Regression Analysis

\begin{tabular}{|c|c|c|c|c|}
\hline \multicolumn{5}{|c|}{ Table B.1: Data for Regression Analysis } \\
\hline Month/Year & $\begin{array}{c}\text { Construction } \\
\text { Worker } \\
\text { Wage } \\
\end{array}$ & $\begin{array}{c}\text { Job } \\
\text { Openings } \\
(000)\end{array}$ & $\begin{array}{c}\text { Construction } \\
\text { Workers } \\
\text { Employed } \\
(\mathbf{0 0 0 )} \\
\end{array}$ & $\begin{array}{c}\text { Average } \\
\text { Wage } \\
\text { All } \\
\text { Workers }\end{array}$ \\
\hline Dec-00 & $\$ 17.78$ & 186 & 5,289 & $\$ 14.28$ \\
\hline Jan-01 & $\$ 17.87$ & 163 & 5,312 & $\$ 14.29$ \\
\hline Feb-01 & $\$ 17.89$ & 173 & 5,325 & $\$ 14.38$ \\
\hline Mar-01 & $\$ 17.92$ & 156 & 5,376 & $\$ 14.42$ \\
\hline Apr-01 & $\$ 17.80$ & 169 & 5,347 & $\$ 14.45$ \\
\hline May-01 & $\$ 17.93$ & 151 & 5,358 & $\$ 14.50$ \\
\hline Jun-01 & $\$ 17.99$ & 142 & 5,354 & $\$ 14.55$ \\
\hline Jul-01 & $\$ 17.98$ & 146 & 5,358 & $\$ 14.56$ \\
\hline Aug-01 & $\$ 18.04$ & 106 & 5,334 & $\$ 14.60$ \\
\hline Sep-01 & $\$ 17.99$ & 120 & 5,314 & $\$ 14.64$ \\
\hline Oct-01 & $\$ 18.06$ & 110 & 5,309 & $\$ 14.66$ \\
\hline Nov-01 & $\$ 18.13$ & 113 & 5,282 & $\$ 14.72$ \\
\hline Dec-01 & $\$ 18.24$ & 95 & 5,302 & $\$ 14.75$ \\
\hline Jan-02 & $\$ 18.27$ & 98 & 5,297 & $\$ 14.76$ \\
\hline Feb-02 & $\$ 18.30$ & 94 & 5,285 & $\$ 14.79$ \\
\hline Mar-02 & $\$ 18.36$ & 108 & 5,257 & $\$ 14.82$ \\
\hline Apr-02 & $\$ 18.41$ & 88 & 5,210 & $\$ 14.83$ \\
\hline May-02 & $\$ 18.41$ & 98 & 5,173 & $\$ 14.88$ \\
\hline Jun-02 & $\$ 18.45$ & 100 & 5,179 & $\$ 14.95$ \\
\hline Jul-02 & $\$ 18.57$ & 80 & 5,161 & $\$ 14.98$ \\
\hline Aug-02 & $\$ 18.56$ & 82 & 5,164 & $\$ 15.02$ \\
\hline Sep-02 & $\$ 18.64$ & 145 & 5,155 & $\$ 15.07$ \\
\hline Oct-02 & $\$ 18.65$ & 118 & 5,147 & $\$ 15.12$ \\
\hline Nov-02 & $\$ 18.68$ & 89 & 5,168 & $\$ 15.15$ \\
\hline Dec-02 & $\$ 18.84$ & 92 & 5,141 & $\$ 15.21$ \\
\hline Jan-03 & $\$ 18.77$ & 92 & 5,121 & $\$ 15.22$ \\
\hline Feb-03 & $\$ 18.82$ & 82 & 5,103 & $\$ 15.29$ \\
\hline Mar-03 & $\$ 18.85$ & 69 & 5,063 & $\$ 15.29$ \\
\hline Apr-03 & $\$ 18.90$ & 116 & 5,090 & $\$ 15.28$ \\
\hline May-03 & $\$ 18.96$ & 89 & 5,093 & $\$ 15.34$ \\
\hline Jun-03 & $\$ 18.99$ & 96 & 5,112 & $\$ 15.36$ \\
\hline Jul-03 & $\$ 18.96$ & 101 & 5,118 & $\$ 15.40$ \\
\hline
\end{tabular}




\begin{tabular}{|c|c|c|c|c|}
\hline \multicolumn{5}{|c|}{ Table B.1: Data for Regression Analysis (Continued) } \\
\hline Month/Year & $\begin{array}{c}\text { Construction } \\
\text { Worker } \\
\text { Wage } \\
\end{array}$ & $\begin{array}{c}\text { Job } \\
\text { Openings } \\
(000) \\
\end{array}$ & $\begin{array}{c}\text { Construction } \\
\text { Workers } \\
\text { Employed } \\
(\mathbf{0 0 0 )} \\
\end{array}$ & $\begin{array}{c}\text { Average } \\
\text { Wage } \\
\text { All } \\
\text { Workers }\end{array}$ \\
\hline Aug-03 & $\$ 18.99$ & 97 & 5,137 & $\$ 15.42$ \\
\hline Sep-03 & $\$ 19.02$ & 56 & 5,154 & $\$ 15.42$ \\
\hline Oct-03 & $\$ 19.00$ & 76 & 5,154 & $\$ 15.43$ \\
\hline Nov-03 & $\$ 19.03$ & 88 & 5,161 & $\$ 15.47$ \\
\hline Dec-03 & $\$ 19.02$ & 93 & 5,180 & $\$ 15.48$ \\
\hline Jan-04 & $\$ 19.10$ & 142 & 5,197 & $\$ 15.51$ \\
\hline Feb-04 & $\$ 19.18$ & 116 & 5,204 & $\$ 15.54$ \\
\hline Mar-04 & $\$ 19.18$ & 102 & 5,232 & $\$ 15.57$ \\
\hline Apr-04 & $\$ 19.20$ & 112 & 5,250 & $\$ 15.60$ \\
\hline May-04 & $\$ 19.22$ & 116 & 5,280 & $\$ 15.64$ \\
\hline Jun-04 & $\$ 19.20$ & 100 & 5,292 & $\$ 15.67$ \\
\hline Jul-04 & $\$ 19.19$ & 94 & 5,313 & $\$ 15.71$ \\
\hline Aug-04 & $\$ 19.22$ & 113 & 5,331 & $\$ 15.75$ \\
\hline Sep-04 & $\$ 19.24$ & 103 & 5,358 & $\$ 15.79$ \\
\hline Oct-04 & $\$ 19.29$ & 116 & 5,400 & $\$ 15.82$ \\
\hline Nov-04 & $\$ 19.30$ & 124 & 5,413 & $\$ 15.85$ \\
\hline Dec-04 & $\$ 19.26$ & 138 & 5,447 & $\$ 15.87$ \\
\hline Jan-05 & $\$ 19.23$ & 129 & 5,417 & $\$ 15.91$ \\
\hline Feb-05 & $\$ 19.31$ & 131 & 5,482 & $\$ 15.93$ \\
\hline Mar-05 & $\$ 19.37$ & 151 & 5,484 & $\$ 15.98$ \\
\hline Apr-05 & $\$ 19.39$ & 120 & 5,557 & $\$ 16.02$ \\
\hline May-05 & $\$ 19.37$ & 114 & 5,575 & $\$ 16.05$ \\
\hline Jun-05 & $\$ 19.41$ & 111 & 5,606 & $\$ 16.08$ \\
\hline Jul-05 & $\$ 19.50$ & 129 & 5,620 & $\$ 16.15$ \\
\hline Aug-05 & $\$ 19.48$ & 133 & 5,647 & $\$ 16.18$ \\
\hline Sep-05 & $\$ 19.50$ & 148 & 5,680 & $\$ 16.20$ \\
\hline Oct-05 & $\$ 19.55$ & 152 & 5,723 & $\$ 16.30$ \\
\hline Nov-05 & $\$ 19.55$ & 165 & 5,793 & $\$ 16.31$ \\
\hline Dec-05 & $\$ 19.63$ & 186 & 5,789 & $\$ 16.37$ \\
\hline Jan-06 & $\$ 19.63$ & 121 & 5,858 & $\$ 16.43$ \\
\hline Feb-06 & $\$ 19.67$ & 130 & 5,886 & $\$ 16.49$ \\
\hline Mar-06 & $\$ 19.67$ & 155 & 5,910 & $\$ 16.55$ \\
\hline Apr-06 & $\$ 19.71$ & 145 & 5,925 & $\$ 16.66$ \\
\hline May-06 & $\$ 19.87$ & 138 & 5,928 & $\$ 16.66$ \\
\hline Jun-06 & $\$ 20.03$ & 168 & 5,919 & $\$ 16.72$ \\
\hline
\end{tabular}




\begin{tabular}{|c|c|c|c|c|}
\hline \multicolumn{5}{|c|}{ Table B.1: Data for Regression Analysis (Continued) } \\
\hline Month/Year & $\begin{array}{c}\text { Construction } \\
\text { Worker } \\
\text { Wage } \\
\end{array}$ & $\begin{array}{c}\text { Job } \\
\text { Openings } \\
(000) \\
\end{array}$ & $\begin{array}{c}\text { Construction } \\
\text { Workers } \\
\text { Employed } \\
(000) \\
\end{array}$ & $\begin{array}{c}\text { Average } \\
\text { Wage } \\
\text { All } \\
\text { Workers }\end{array}$ \\
\hline Jul-06 & $\$ 20.06$ & 153 & 5,919 & $\$ 16.79$ \\
\hline Aug-06 & $\$ 20.11$ & 185 & 5,933 & $\$ 16.83$ \\
\hline Sep-06 & $\$ 20.17$ & 148 & 5,916 & $\$ 16.88$ \\
\hline Oct-06 & $\$ 20.24$ & 137 & 5,881 & $\$ 16.95$ \\
\hline Nov-06 & $\$ 20.37$ & 106 & 5,876 & $\$ 16.99$ \\
\hline Dec-06 & $\$ 20.44$ & 107 & 5,868 & $\$ 17.07$ \\
\hline Jan-07 & $\$ 20.55$ & 142 & 5,916 & $\$ 17.12$ \\
\hline Feb-07 & $\$ 20.57$ & 229 & 5,819 & $\$ 17.17$ \\
\hline Mar-07 & $\$ 20.68$ & 152 & 5,900 & $\$ 17.24$ \\
\hline Apr-07 & $\$ 20.73$ & 154 & 5,878 & $\$ 17.29$ \\
\hline May-07 & $\$ 20.91$ & 157 & 5,890 & $\$ 17.34$ \\
\hline Jun-07 & $\$ 20.92$ & 139 & 5,917 & $\$ 17.41$ \\
\hline Jul-07 & $\$ 20.94$ & 167 & 5,912 & $\$ 17.47$ \\
\hline Aug-07 & $\$ 20.99$ & 149 & 5,886 & $\$ 17.51$ \\
\hline Sep-07 & $\$ 21.10$ & 138 & 5,867 & $\$ 17.57$ \\
\hline Oct-07 & $\$ 21.05$ & 155 & 5,855 & $\$ 17.59$ \\
\hline Nov-07 & $\$ 21.20$ & 144 & 5,818 & $\$ 17.64$ \\
\hline Dec-07 & $\$ 21.25$ & 160 & 5,774 & $\$ 17.71$ \\
\hline
\end{tabular}

(Source: Bureau of Labor Statistics, 2008a, 2008b, 2008c, and 2008d) 


\section{Appendix C: Residual Plots for Multiple Regression Analysis}

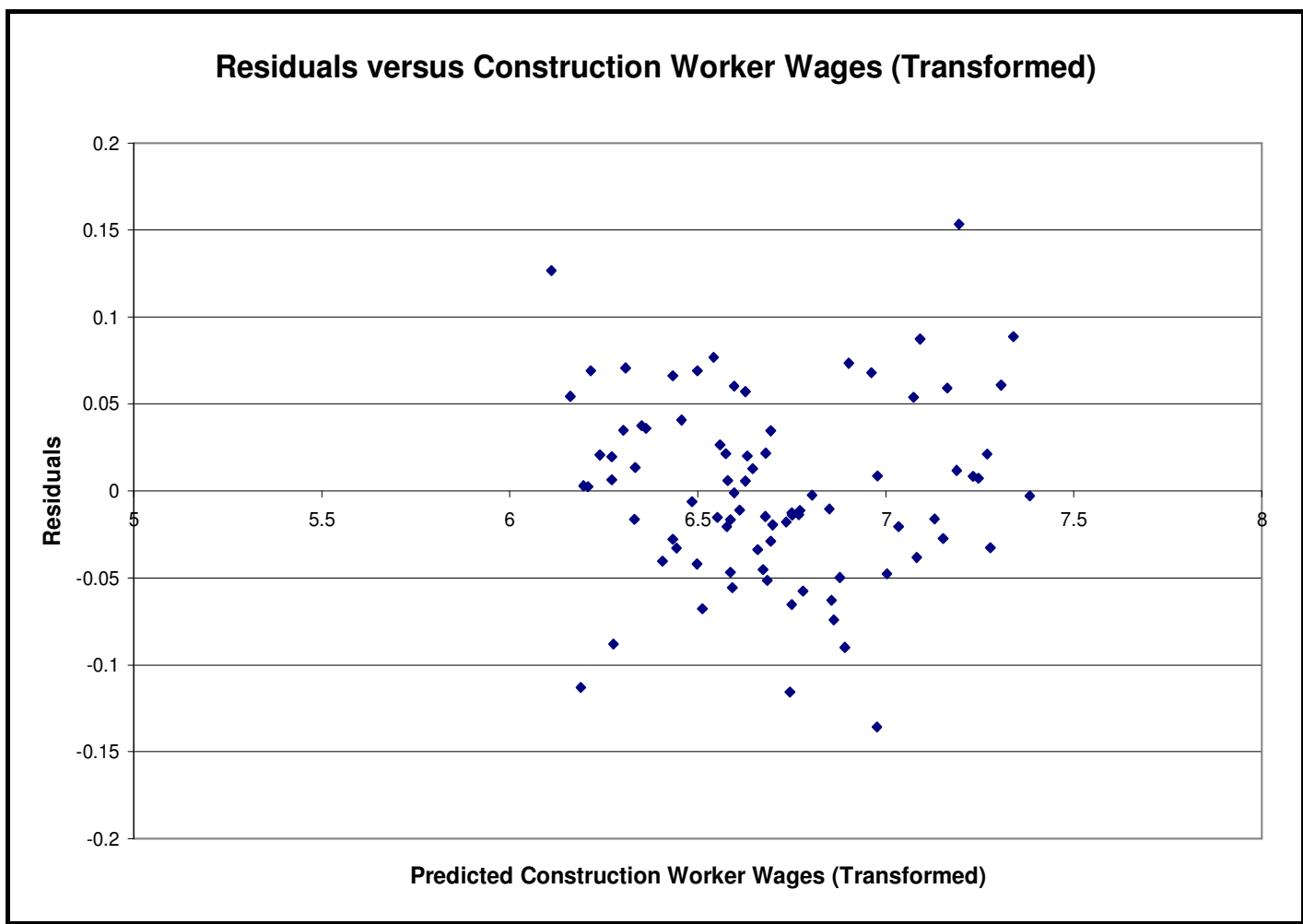

Figure C.1: Residuals versus Construction Worker Wages (Transformed)

The first residual plot examines the pattern of residuals for the predicted values of $\mathrm{y}_{\mathrm{t}}$.

The lack of apparent pattern in the residuals indicates the aptness of the fit of the regression model. 


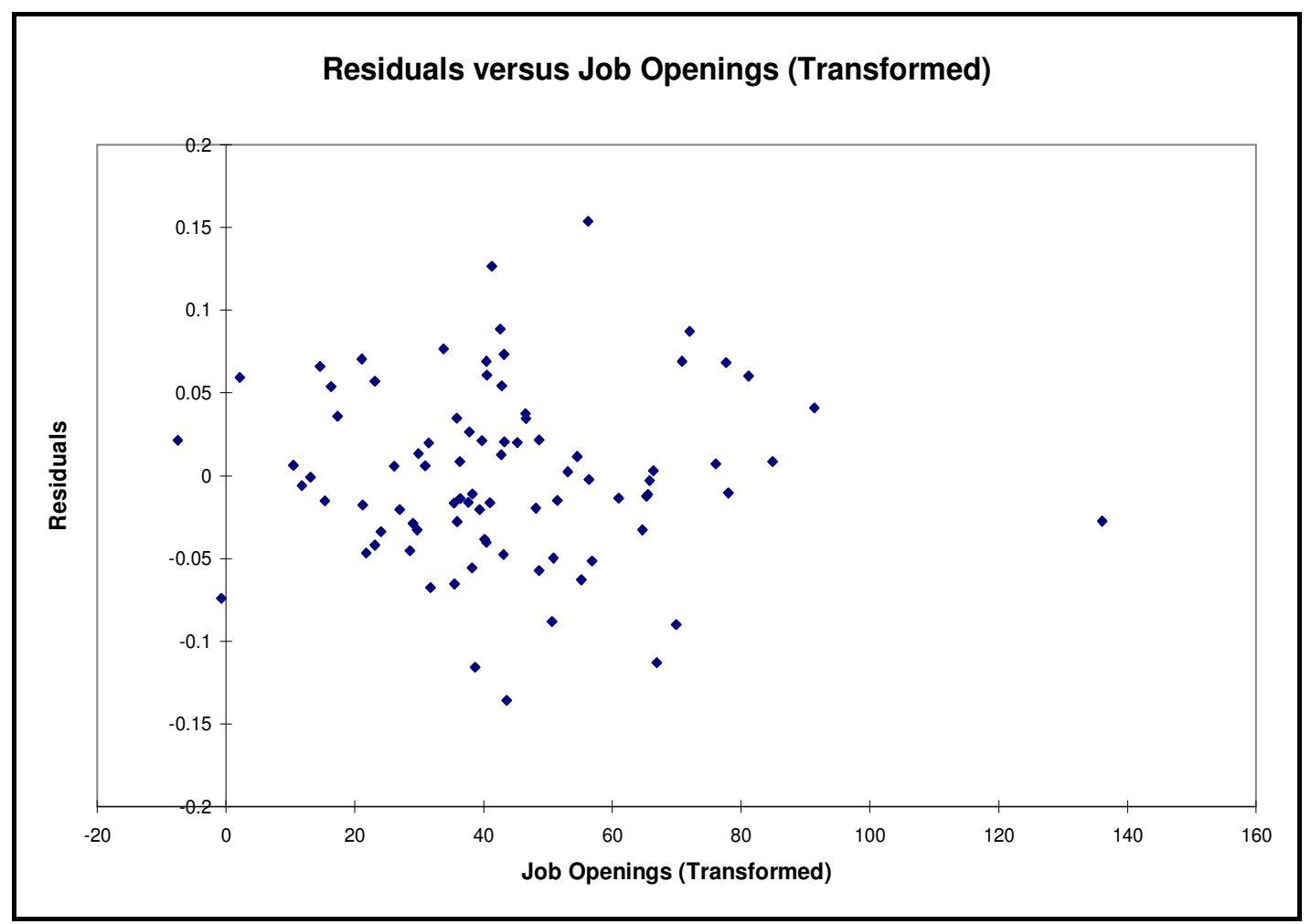

Figure C.2: Residuals versus Job Openings (Transformed)

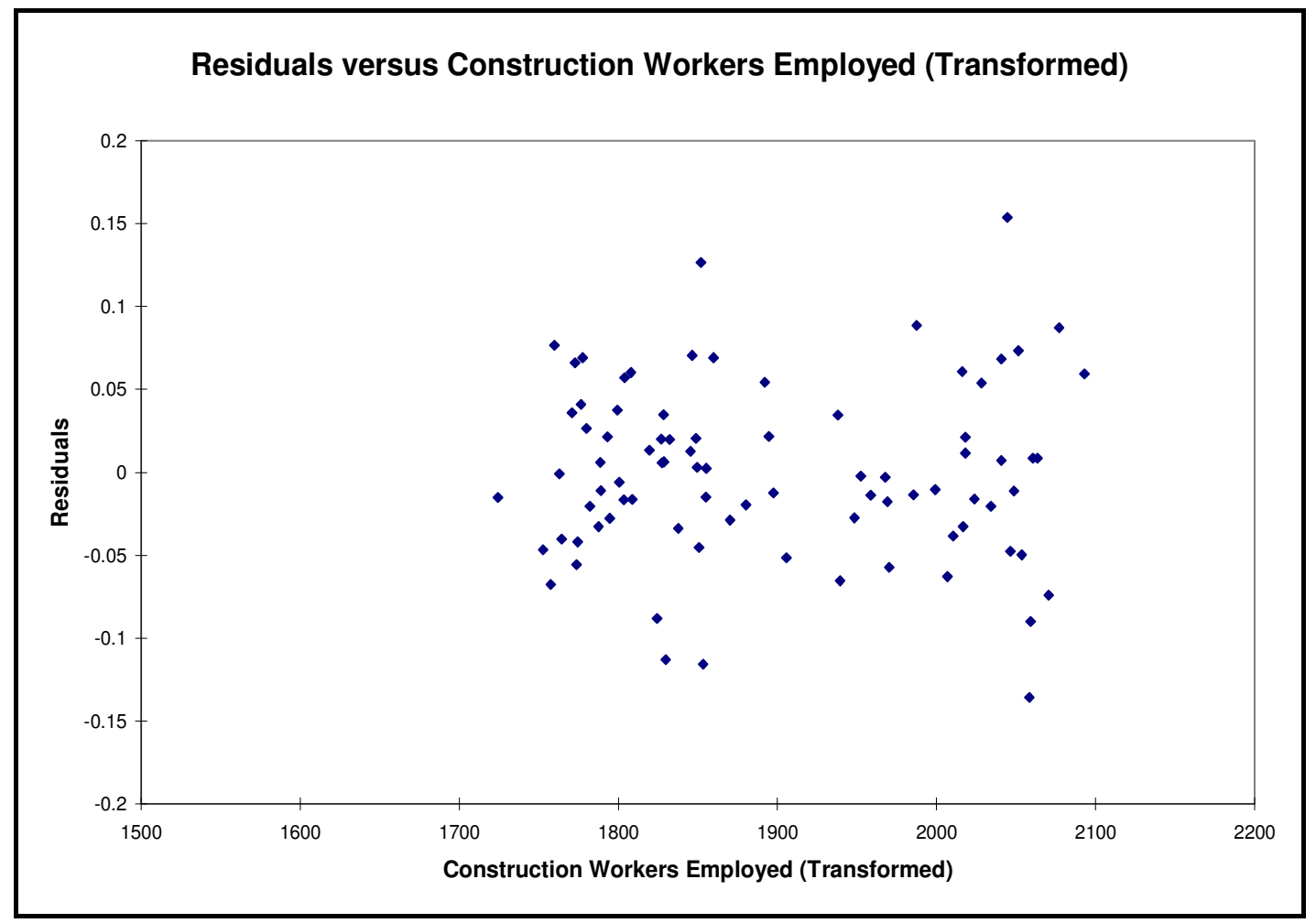

Figure C.3: Residuals versus Construction Workers Employed (Transformed) 


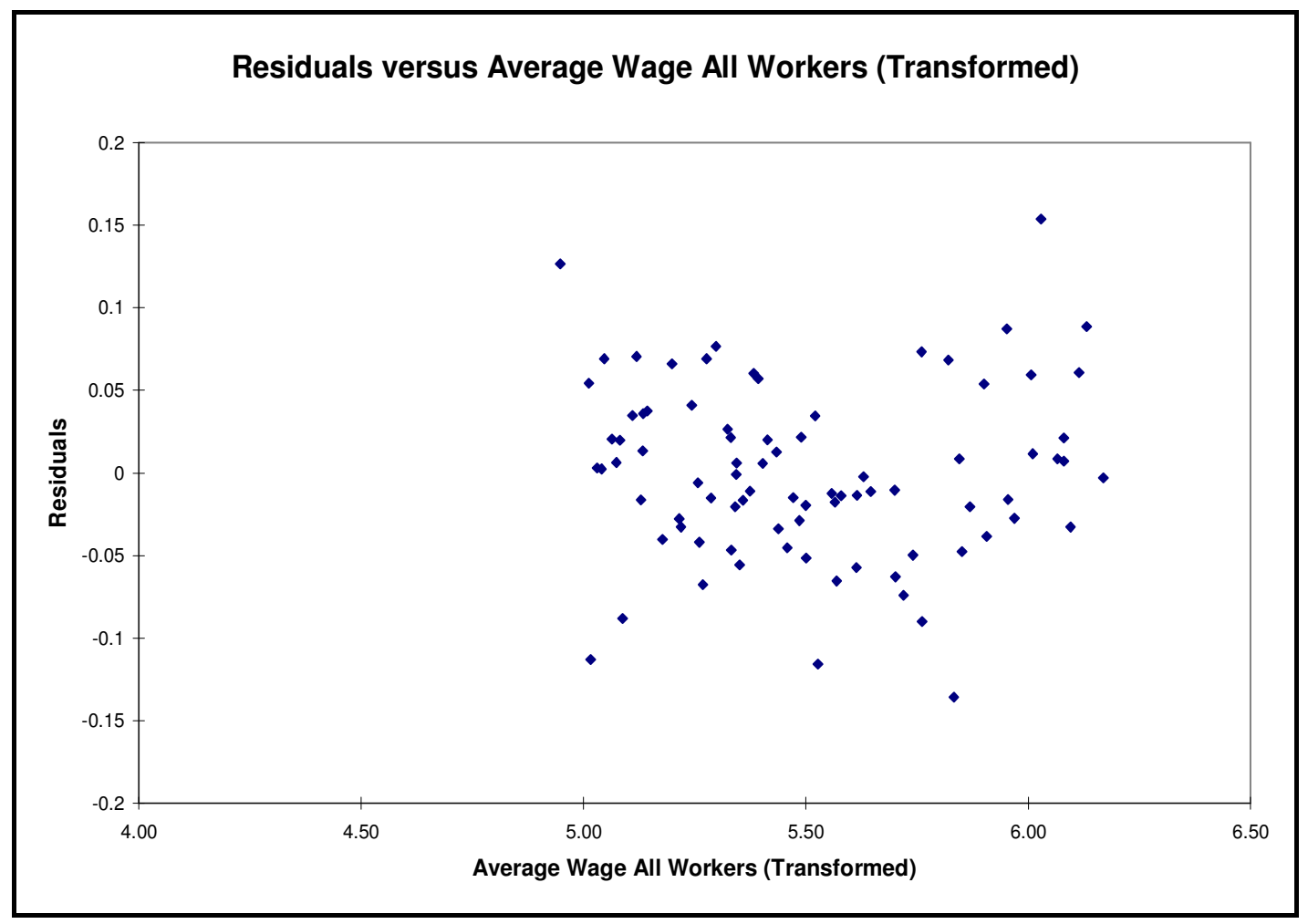

Figure C.4: Residuals versus Average Wage of All Workers (Transformed)

Figures C.2 through C.4 show the plots of residuals versus the transformation of the dependent variables. There is no apparent pattern in the relationship of the residuals and the values of the dependent variables. Additionally, the residuals appear to be evenly spread above and below zero. Therefore, the conclusion is that the multiple linear regression model is appropriate in predicting the wages for construction workers. 


\section{Appendix D: Construction Project Cost Data}

\section{Table D1: Construction Project Cost Data}

\begin{tabular}{|lr|}
\hline Project 1 & \\
Concrete & $\$ 23,581,171$ \\
Masonry & $\$ 1,941,000$ \\
Drywall & $\$ 4,255,298$ \\
Terrazzo & $\$ 556,538$ \\
Painting & $\$ 496,495$ \\
Flooring & $\$ 70,425$ \\
& \\
Total & $\$ 30,900,927$ \\
\hline
\end{tabular}

\begin{tabular}{|lr|}
\hline Project 4 & \\
Concrete & $\$ 11,958,750$ \\
Masonry & $\$ 1,470,499$ \\
Drywall & $\$ 3,487,150$ \\
Painting & $\$ 279,000$ \\
Flooring & $\$ 2,307,391$ \\
Roofing & $\$ 539,087$ \\
& \\
Total & $\$ 20,041,877$ \\
\hline
\end{tabular}

\begin{tabular}{|lr|}
\hline Project 2 & \\
Concrete & $\$ 9,370,967$ \\
Masonry & $\$ 3,607,385$ \\
Drywall & $\$ 2,721,000$ \\
Terrazzo & $\$ 13,500$ \\
Painting & $\$ 279,000$ \\
Flooring & $\$ 976,081$ \\
Roofing & $\$ 937,240$ \\
& \\
Total & $\$ 17,905,173$ \\
\hline
\end{tabular}

\begin{tabular}{|lr|}
\hline Project 5 & \\
Concrete & $\$ 27,264,985$ \\
Masonry & $\$ 649,935$ \\
Drywall & $\$ 3,151,216$ \\
Painting & $\$ 416,374$ \\
Flooring & $\$ 368,681$ \\
Roofing & $\$ 1,120,000$ \\
& \\
Total & $\$ 32,971,191$ \\
\hline
\end{tabular}

\begin{tabular}{|lr|}
\hline Project 3 & \\
Concrete & $\$ 13,590,000$ \\
Masonry & $\$ 3,198,250$ \\
Drywall & $\$ 6,206,725$ \\
Painting & $\$ 745,000$ \\
Flooring & $\$ 1,298,075$ \\
Roofing & $\$ 1,085,250$ \\
& \\
Total & $\$ 26,123,300$ \\
\hline
\end{tabular}




\section{Bibliography}

Aizenman, N. C. (2007, December 19). D.C. area a stop in Salvadoran Campaign. The Washington Post. Retrieved March 7, 2008 from www.washingtonpost.com.

Altonji, J. G. and Card, D. (1991). The effects of immigration on the labor market outcomes of less-skilled natives. In J. M. Abowd and R. B. Freeman (Eds.) Immigration, Trade, and the Labor Market, (pp. 201-234). Chicago: University of Chicago Press.

Bean, F. D., Lowell, B. L., and Taylor, L. J. (1988, February). Undocumented Mexican immigrants and the earnings of other workers in the United States. Demography, 25, 1, 35-52.

Borjas, G. J. (1990). Friends or Strangers: The impact of immigrants on the U.S. economy. New York: Basic Books.

Borjas, G. J., Freeman, R. B., and Katz, L. F. (1993). On the labor market effects of immigration and trade. In G. Borjas and R. Freeman (Eds.), Immigration and the Workforce. (pp. 213-244). Chicago: University of Chicago Press.

Borjas, G. J. (1994, December). The economics of immigration. Journal of Economic Literature, XXXII, 1667-1717.

Borjas, G. J. (2003, November). The labor demand curve is downward sloping: Reexamining the impact of immigration on the labor market. Quarterly Journal of Economics. 1335-1374. 
Borjas, G. J. (2004, May). Increasing the supply of labor through immigration: Measuring the impact on native-born workers. Backgrounder. Retrieved April 3, 2008 from http://www.cis.org/articles/index.html.

Borjas, G. J. (2006). Native internal migration and labor market impact of immigration. The Journal of Human Resources. XLI, 2, 221-258.

Buffett, S. E. (2007, March 16). Walking the Tightrope: I-9 Compliance and Employer Sanctions. Presentation given at a meeting of the Associated Builders and Contractors, Beltsville, Maryland.

Bureau of Economic Analysis (2007). Gross domestic product by industry accounts. Retrieved April 26, 2007 from www.bea.gov.

Bureau of Labor Statistics. (2007, December). Employer costs for employee compensation. $\quad$ News. Retrieved April 9, 2008 from http://www.bls.gov/news.release/pdf/ecec.pdf.

Bureau of Labor Statistics. (2008a). Average Hourly Earnings of Production Workers, Construction. Series ID: CES2000000008. Retrieved March 6, 2008 from www.bls.gov.

Bureau of Labor Statistics. (2008b). Average Hourly Earnings of Production Workers, Total Private. Series ID: CES0500000008. Retrieved March 6, 2008 from www.bls.gov.

Bureau of Labor Statistics. (2008c). Job Openings and Labor Turnover Survey. Series ID: JTS23000000JOL. Retrieved March 6, 2008 from www.bls.gov. 
Bureau of Labor Statistics. (2008d). Production Workers, Thousands, Construction. Series ID: CES2000000006. Retrieved March 6, 2008 from www.bls.gov.

Bureau of Labor Statistics. (2008e). Workforce Statistics, Construction Industry. Retrieved April 3, 2008 from www.bls.gov..

Bureau of Labor Statistics. (2008f). Working in the $21^{\text {st }}$ century. Retrieved March 7, 2008 from http://www.bls.gov/opub/working/page2b.htm.

Butcher, K. F. and Card, D. (1991). Immigration and wages: Evidence from the 1980s. American Economic Review. 81, 292-296.

Camarota, S. A. (1997, June). The effect of immigrants on the earnings of lowskilled native workers: Evidence from the June 1991 Current Population Survey. Social Science Quarterly, 78, 2, 417-431.

Camarota, S. A. (2004, August). The high cost of cheap labor: Illegal immigration and the federal budget. Washington, D.C.: Center for Immigration Studies. Retrieved April 3, 2008 from http://www.cis.org/articles/index.html.

Camarota, S. A. (2005, December). Immigrants at mid-decade: A snapshot of America's foreign-born population in 2005. Washington, D.C.: Center for Immigration Studies. $\quad$ Retrieved April 3, 2008 from http://www.cis.org/articles/index.html.

Camarota, S. A. (2006, June). Amnesty under Hagel-Martinez: An estimate of how many will legalize if S.2611 becomes law. Backgrounder. Retrieved April 3, 2008 from http://www.cis.org/articles/index.html. 
Card, D. (1990). The impact of the Mariel Boatlift on the Miami labor market. Industrial and Labor Relations Review. XLIII, 245-257.

Card, D. and DiNardo, J. (2000, May). Do immigrant inflows lead to native outflows? The American Economic Review, 90, 2, 360-367.

Casso, M. A. (2006, May 1). CEO leaders of the design \& construction community adopt position to address illegal immigration controversy. McLean, Virginia: Construction Industry Round Table. Retrieved June 13, 2006 from www.cirt.org.

Chatterjee, S. and Hadi, A. S. (2006). Regression Analysis by Example. Hoboken, New Jersey: John Wiley \& Sons, Inc.

Cochrane, D. and Orcutt, G. H. (1949). Application of Least Squares Regression to Relationships Containing Autocorrelated Error Terms. Journal of the American Statistical Association. 44, 32-61.

The Constitution of the United States (1787, September 17).

Costanzo, J. M., Davis, C. J., and Malone, N. (2002, October). Guide to international migration statistics: The sources, collection, and processing of foreign-born population data at the U.S. Census Bureau. (Population Division Working Paper Series No. 68). Retrieved April 3, 2008 from http://www.census.gov/population/www/documentation/twps0068/twps0068. $\underline{\text { html. }}$

Frey, W. H. (1994, April). The new white flight. American Demographics, 16, 4, 048. 
Frey, W. H. (1995, March). Immigration and internal migration "flight": A California case study. Population and Environment, Vol. 16, 4.

Friedberg, R. M. and Hunt, J. (1995). The impact of immigration on host country wages, employment, and growth. Journal of Economic Perspectives, IX, 2344.

Government Accountability Office. (1999, November). Survey methodology: An innovative technique for estimating sensitive survey items. (GAO/GGD-0030). $\quad$ Retrieved April 3, 2008 from http://www.gao.gov/new.items/gg00030.pdf.

Government Accountability Office. (2006, September). Estimating the undocumented population: A "grouped answers" approach to surveying foreign-born respondents. Report to the Subcommitee on Terrorism, Technology, and Homeland Security, Committee on the Judiciary, U.S. Senate. (GAO-06-775). $\quad$ Retrieved April 3, 2008 from http://www.gao.gov/new.items/d06775.pdf.

Golden, S. K. and Skibniewski, M. J. (2007a). A critical analysis of the short-term and long-term effects of immigrant hiring practices and pending immigration reform on project costs. Presentation May, 24, 2007.

Golden, S. K. and Skibniewski, M. J. (2007b, July). Immigration and the construction industry: Effects of immigrant hiring practices and pending immigration reform legislation on construction industry economics in the United States. CME 25 Conference: Construction Management and Economics, 'Past, Present, and Future.' 
Golden, S. K. and Skibniewski, M. J. (2008a). Immigration and construction: An analysis of the impact of immigration on construction project costs in the United States. Manuscript submitted for publication.

Golden, S. K. and Skibniewski, M. J. (2008b). Immigration and construction: The impact of reform legislation on worker wages. Manuscript submitted for publication.

Golden, S. K. and Skibniewski, M. J. (2008c). Immigration and construction: The makeup of the workforce in the Washington, D.C. metropolitan area. Manuscript submitted for publication.

Grossman, J. B. (1982, November). The substitutability of natives and immigrants in production. The Review of Economics and Statistics, 64, 4, 596-603.

Gurak, D. T. and Caces, F. (1992). Migration networks and the shaping of migration systems. In M. M. Kritz, L. L. Lim, and H. Zlotnick (Eds.), International Migration Systems: A Global Approach (pp. 150-176). Oxford: Clarendon.

Hamermesh, D.S. (1986). The demand for labor in the long run. In O. Ashenfelter and R. Layard. (Eds.), Handbook of Labor Economics. Amsterdam: Elsevier Science Publishers.

House of Representatives, U.S. Congress (2006, January 27). Border Protection, Antiterrorism, and Illegal Immigration Control Act of 2005, H. R. 4437.

Johnson, C. W. (2003, June 20). How our laws are made. Washington, D.C.: House of Representatives. (Document 108-93). 
Kochhar, R. (2005, May 2). Latino Labor Report 2004: More jobs for new immigrants but at lower wages. Washington, D.C.: Pew Hispanic Center. Retrieved April 3, 2008 from http://pewhispanic.org/reports/archive/.

LaLonde, R. J. and Topel, R. H. (1991). Labor market adjustments to increased immigration. In J. M. Abowd and R. B. Freeman (Eds.) Immigration, Trade, and the Labor Market, (pp. 167-199). Chicago: University of Chicago Press.

Marcelli, E. A. and Lowell, B. L. (2005, Spring). Transnational twist: Pecuniary remittances and the socioeconomic integration of authorized and unauthorized Mexican immigrants in Los Angeles County. International Migration Review, 39, 1, 69-102.

Masey, D. S. and España, F. G. (1987). The social process of international migration. Science, 237, 733-738.

McClellan, J. L. and Holden, R. (2001). The new workforce: Age and ethnic changes. California Employment and Development Department, Labor Market Information Division. Retrieved March 7, 2008 from http://wdr.doleta.gov/conference/pdf/holden.pdf.

Muller, T. and Epenshade, T. (1985). The fourth wave: California's newest immigrants. Washington, D.C.: Urban Institute Press.

Narayanan, S. and Lai, Y. (2005). The causes and consequences of immigrant labour in the construction sector in Malaysia. International Migration, 43, 5, 31-57. 
The National Research Council. (1997). The new Americans: Economic, demographic, and fiscal impacts of immigration. Commission of Behavioral and Social Sciences and Education. Washington, D.C: The National Academies Press. $\quad$ Retrieved April 2, 2008 from WwW.natinonalacademies.org/nrc.

North, D. and Houstoun, M. F. (1976). Characteristics and role of illegal aliens in the U.S. labor market. Washington, DC: Linton and Co.

Orrenius, P. M. and Zavodny, M. (2001, October). Do amnesty programs encourage illegal immigration? Evidence from IRCA. Dallas, Texas: Federal Reserve Bank of Dallas. (Research Department Working Paper 0103).

Palloni, A., Massey, D. S., Ceballos, M., Espinosa, K., and Spittel, M. (2001, March). Social capital and international migration: A test using information on family networks. The American Journal of Sociology, 106, 5, 1262-1299.

Passel, J. S. and Clark, R. L. (1998, April 1). Immigrants in New York: Their legal status, incomes, and taxes. Washington, D.C.: Urban Institute. Retrieved April 3, 2008 from http://www.urban.org/publications/407432.html.

Passel, J. S., Van Hook, J., and Bean, F. D. (2004, June 1). Estimates of the legal and unauthorized foreign-born population for the United States and selected states based on census 2000. Report to the Census Bureau. Washington, DC.: Urban Institute. Retrieved April 3, 2008 from 
Passel, J. S. (2005, June 14). Unauthorized migrants: Numbers and characteristics. Background briefing prepared for task force on immigration and America's future. Background Brief prepared for Task Force on Immigration and America's Future. Washington, D.C.: Pew Hispanic Center. Retrieved April 3, 2008 from www.pewhispanic.org.

Passel, J. S. (2006, March 7). The size and characteristics of the unauthorized migrant population in the U.S.: Estimates based on March 2005 Current Population Survey. Research Report. Washington, D.C.: Pew Hispanic Center. Retrieved April 3, 2008 from www.pewhispanic.org.

Pew Hispanic Center. (2006a, April 5). Recently arrived migrants and the Congressional debate on immigration. Fact Sheet. Washington, D.C.: Pew Hispanic Center. Retrieved April 3, 2008 from http://pewhispanic.org/factsheets/.

Pew Hispanic Center. (2006b, April 13). The labor force status of short-term unauthorized workers. Fact Sheet. Washington, D.C.: Pew Hispanic Center. Retrieved April 3, 2008 from http://pewhispanic.org/factsheets/.

Rea, L. M. and Parker, R. A. (1993). Illegal immigration in San Diego County: An analysis of costs and revenues. Report to California State Senate Special Committee on Border Issues.

Rector, R. (2006, May 15). Senate immigration bill would allow 100 million new legal immigrants over the next twenty years. Web Memo. Washington, D.C.: The Heritage Foundation. Retrieved April 3, 2008 from www.heritage.org. 
Schmidley, A. D. and Robinson, J. G. (1998, April). How well does the Current Population Survey measure the foreign born population in the United States? (Population Division Working Paper No. 22). Retrieved July 5, 2007 from http://www.census.gov/population/www/documentation/twps0022/twps0022. $\underline{\mathrm{html}}$.

Senate, U.S. Congress. (2006, April 7). Comprehensive Immigration Reform Act of 2006, S. 2611.

Senate, U.S. Congress. (2007, June 18) Secure Borders, Economic Opportunity, and Immigration Reform Act of 2007, S.1639.

Sherk, J. (2006, July 27). Davis-Bacon wages in Senate immigration bill would keep immigrants in the underground economy. Web Memo. Washington, D.C.: The Heritage Foundation. Retrieved April 3, 2008 from www.heritage.org.

Sherk, J. (2007, May 29). Senate immigration bill marred by prevailing wage provision. Web Memo. Washington, D.C.: The Heritage Foundation. Retrieved April 3, 2008 from www.heritage.org.

Simon, J. L., Moore, S., and Sullivan, R. (1993, Summer). The effect of immigration on aggregate native unemployment: An across-city estimation. Journal of Labor Research, 14, 3, 299-316.

Veneri, C. M. (1999, March). Can occupational labor shortages be identified using available data? Monthly Labor Review, 15-21. 
Winegarden, C. R. and Khor, L. B. (1991, February). Undocumented immigration and unemployment of U.S. youth and minority workers: Econometric evidence. The Review of Economics and Statistics, 73, 1, 105-112. 